\author{
UNIVERSIDADE DE BRASíLIA \\ FACULDADE DE CIÊNCIAS DA SAÚDE \\ PROGRAMA DE PÓS-GRADUAÇÃO EM BIOÉTICA
}

DARIO MARTINS PALHARES DE MELO

CUIDADOS PALIATIVO EM CRIANÇAS PORTADORAS DE MALFORMAÇÕES CEREBRAIS

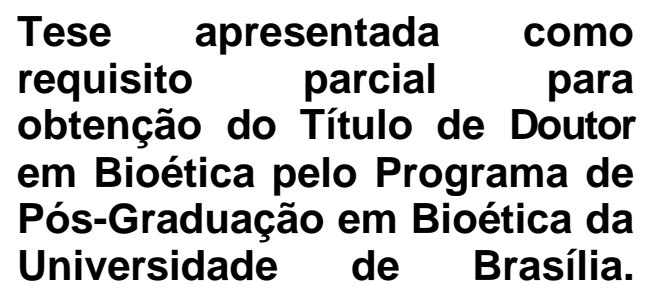

Orientador: Prof. Dr. Antônio Carlos Rodrigues da Cunha

BRASÍLIA - DF 


\section{CUIDADOS PALIATIVO EM CRIANÇAS PORTADORAS DE MALFORMAÇÕES CEREBRAIS}

\begin{abstract}
Tese apresentada como requisito parcial para obtenção do Título de Doutor em Bioética pelo Programa de PósGraduação em Bioética da Universidade de Brasília
\end{abstract}

BANCA EXAMINADORA

Presidente:

Prof. Dr. Antônio Carlos Rodrigues da Cunha

Membros:

Dr. Nélson Diniz de Oliveira

Profa. Dra. Ceres Nunes Resende Oyama

Prof. Dr. Gabriele Cornelli

Profa. Dra. Tereza Cristina Cavalcanti Ferreira de Araújo 
Dedico este trabalho a todas as famílias que se regozijam de suas crianças crescendo felizes, fortes e saudáveis e, sobretudo, às famílias que enfrentam o desafio de cuidarem de crianças em condições graves de saúde. 


\section{AGRADECIMENTOS}

A meus pais, por tudo.

Ao Programa de Pós-Graduação em Bioética, pela oportunidade oferecida.

Ao expoente bioeticista, Prof. Dr. Volnei Garrafa, pelo pioneirismo, pelo trabalho de excelência e pela oportunidade oferecida.

Ao Orientador, Prof. Dr. Antônio Carlos Rodrigues da Cunha, por todo o suporte ao longo desta jornada.

A todos os professores das disciplinas, pelos ensinamentos.

Aos palestrantes das conferências, pelas atualizações e pelo estímulo à reflexão.

À companheira Íris, por ter-me encorajado a desbravar o caminho da Bioética.

Aos funcionários atuais e que já atuaram nas Secretarias, pela fluência e paciência com as lides administrativas

Aos colegas do curso, pelas conversas, pelo brainstorm e pelo companheirismo. 


\section{RESUMO}

A limitação terapêutica das crianças portadoras de malformações cerebrais é uma interseção entre pelo menos três grandes tópicos da Bioética: os cuidados paliativos, a neuroética e a heteronomia da infância. Dessa forma, foi preciso sintetizar os principais tópicos de discussão para a proposta geral e específica para esse grupo de pacientes pediátricos. Os princípios éticos dos cuidados paliativos surgem concomitantemente ao extraordinário desenvolvimento tecnológico na área biomédica. Os cuidados paliativos chegam à conclusão ética que, para doenças muito graves, o melhor tratamento passa a ser o de não utilizar tratamentos invasivos e ater-se aos cuidados de alívio dos sintomas. Em um contexto mundial, os países que contam com um sistema público de saúde bem consolidado são os que mais investem nos cuidados paliativos. Em um panorama mundial, os países menos desenvolvidos vivenciam um duplo conflito bioético: por um lado, a grande maioria dos habitantes não consegue acesso adequado aos serviços de saúde; por outro, os que têm acesso ao hospital vêem os cuidados de fim de vida serem caracterizados por obstinação terapêutica e aplicação inadequada de cuidados intensivos. Nesse contexto, a situação do Brasil é intermediária: estão surgindo aos documentos com valor legal para colocar freio à obstinação terapêutica e já há alguns serviços estruturados de cuidados paliativos, mas, no geral, os pacientes graves morrem em um contexto clínico de obstinação terapêutica. Quando se trata da faixa etária pediátrica, a criança vivencia uma situação de heteronomia que não adquire o mesmo valor ético para o adulto, uma vez que a condição heterônoma da criança é essencialmente uma situação de tutela e proteção, tanto dos riscos externos como de sua própria imaturidade. As crianças portadoras de malformações cerebrais, em geral, apresentam curta expectativa de vida, na qual a deterioração de saúde não é continuada, mas ocorre após cada intercorrência clínica. Ou seja, se nos cuidados paliativos do câncer já existem indicativos de irreversibilidade clínica, para as crianças com malformações cerebrais esses dados ainda não estão consolidados. De todo modo, cabe à equipe médica reconhecer a situação de terminalidade de vida e com isso propor a limitação terapêutica. É uma decisão tomada em um processo dialógico, o qual exige algum tempo e mais de uma reunião entre a equipe médica e os pais ou responsáveis pela criança. A primeira decisão a ser tomada é a ordem de não-reanimação cardiorrespiratória, a qual representa mais um marco ético e simbólico do que uma limitação de esforços. De modo quase concomitante, essa decisão se associa, administrativamente, à nãoindicação de internação em unidade de terapia intensiva, pois, são locais de tratamentos intensivos, e esses pacientes necessitam de cuidados paliativos. Os tratamentos passíveis de restrição são essencialmente suporte respiratório avançado, cirurgias de grande porte e a questão neuroética inclui no debate se suporte nutricional por sonda é passível ou não de limitação. As unidades de saúde que atendem a crianças portadoras de malformações cerebrais devem, portanto, se organizar no sentido de promover ambiente para que a limitação terapêutica seja consolidada como prática rotineira de cuidados de fim de vida.

Palavras-chave: terminalidade de vida, anencefalia, hospital, futilidade terapêutica. 


\begin{abstract}
Therapeutic limitation of children with brain malformations is an intersection between at least three major topics of bioethics: palliative care, neuroethics and childhood heteronomy. In a historical context, the ethical principles of palliative care arise concurrently with the extraordinary technological development in biomedical consolidated throughout the twentieth century. Palliative care is subversive because they show the technical and ethical limits of intensive care and concluded that for very, very serious illnesses, the best treatment becomes not to use invasive treatments and stick to the relief care of symptoms . However, in a global context, it is precisely those countries with a public health system more consolidated those who invest more in palliative care. Limit treatment does not mean abandoning the patient to their own devices, but in a world panorama, the least developed countries experience a double bioethical conflict: on the one hand, the vast majority of people can not have adequate access to health services; on the other, those who have access to the hospital see the end of life care is characterized by therapeutic obstinacy and misapplication of intensive care. In this context, Brazil's situation is intermediate: are emerging gradually ethical codes with legal value to put brake to therapeutic obstinacy and there are already some structured palliative care services, but, in general, critically ill patients die in a clinical context of obstinacy therapy. When it comes to the pediatric age group, discussions on heteronomy also undermine one of the fundamental values of Clinical Bioethics that is respect for patient autonomy. The child, however, experience a heteronomy situation that does not get the same value for the adult, since the child heteronomous condition is essentially a situation of guardianship and protection, both external risks as their own immaturity. Children with brain malformations are faced with value issues relating to neuroethics, ie the current bioethics that sees the brain as the organ-seat of the human condition in its fullest expression. These children generally have a short life expectancy, in which the deterioration of health is not continuous, but occurs after each clinical complications. That is, if the cancer palliative care are already indicative of clinical irreversibility, for children with brain malformations such data are not yet consolidated. In any case, it is for the medical staff to recognize the situation of terminally life and therefore offer a therapeutic limitation. It is a decision taken in a dialogical process, which takes time and over a meeting between the medical staff and the parents or guardians. The first decision to be made is the order of cardiorespiratory non-resuscitation, which is more an ethical and symbolic milestone than a limitation efforts. Almost concomitantly, this decision is associated administratively non-statement of admission to the intensive care unit - ICU - because, as the name implies, are places of intensive treatments, and these patients require palliative care. Treatments subject to restriction are essentially advanced respiratory support, major surgeries and neuroethics includes question in the debate is nutritional support for probe is capable or not of limitation. Health facilities that serve children with brain malformations should therefore be organized to promote environment for therapeutic limitation is established as routine practice of end of life care.
\end{abstract}

Key words: end of life care, anencephaly, hospital, therapeutical futility 


\section{LISTA DE ABREVIAÇÕES}

ANCP - Associação Nacional de Cuidados Paliativos

CFM - Conselho Federal de Medicina

Cremeb - Conselho Regional de Medicina da Bahia

Cremesp - Conselho Regional de Medicina do Estado de São Paulo

ECOG - Eastern Cooperative Oncology Group

EUA - Estados Unidos da América

OMS - Organização Mundial da Saúde

UTI - Unidade de Terapia Intensiva

UTIPed - Unidade de Terapia Intensiva Pediátrica 


\section{LISTA DE FIGURAS}

Figura 1 - Modelos qualitativos de fim de vida em relação à vitalidade. 


\section{ÍNDICE}

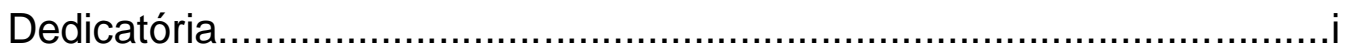

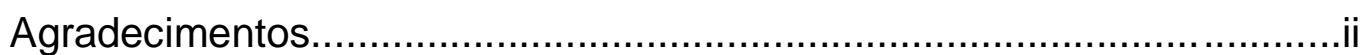

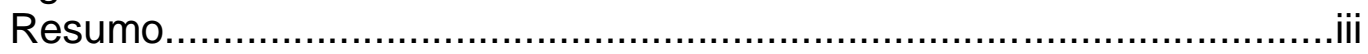

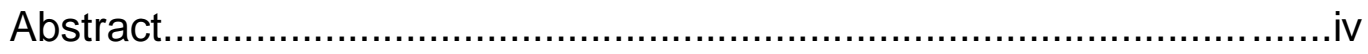

Lista de Abreviações.......................................................................

Lista de Figuras................................................................................

INTRODUÇÃO GERAL

PARTE I - FUNDAMENTAÇÃO 4

1 - Breve sinopse das principais malformações cerebrais 4

2 - Ética dos Cuidados Paliativos e da Limitação Terapêutica 9

Introdução $\quad 9$

Histórico $\quad 11$

Futilidade terapêutica $\quad 15$

Princípios dos Cuidados Paliativos $\quad 27$

Peculiaridades da Pediatria 33

Classificação por níveis de risco 37

As últimas 48 horas de vida 38

Limitação terapêutica $\quad 39$

Aspectos jurídicos da limitação terapêutica $\quad 41$

3 - Neuroética 44

Anencefalia $\quad 47$

Morte cerebral e estado comatoso irreversível $\quad 50$

4 - Autonomia, dignidade e responsabilidade profissional 51

$\begin{array}{ll}\text { Autonomia } & 57\end{array}$

Conceito 57

Autonomia e responsabilidade profissional 59

Dignidade 62

Conceito 62

Dignidade nos cuidados de fim de vida 63

Responsabilidade médica $\quad 65$

5 - A heteronomia do paciente pediátrico 66

PARTE II - REVISÃO SISTEMÁTICA E ESTUDO DE CASOS 74 
1- Revisão Sistemática De Literatura $\quad 74$

$\begin{array}{ll}\text { Introdução } & 74\end{array}$

Objetivos $\quad 75$

Objetivo geral $\quad 75$

Objetivos específicos $\quad 75$

$\begin{array}{ll}\text { Metodologia } & 75\end{array}$

$\begin{array}{ll}\text { Resultados } & 77\end{array}$

2 - Estudo de casos $\quad 87$

$\begin{array}{ll}\text { Introdução } & 87\end{array}$

$\begin{array}{ll}\text { Casos } & 87\end{array}$

Análise dos casos $\quad 89$

DISCUSSÃO GERAL E CONSIDERAÇÕES FINAIS 94

$\begin{array}{lr}\text { REFERÊNCIAS BIBLIOGRÁFICAS } & 100\end{array}$ 


\section{INTRODUÇÃO GERAL}

Os cuidados de final de vida de crianças portadoras de malformações cerebrais se posicionam em uma perspectiva concernente à interseção dos tópicos de Neuroética, Ética dos Cuidados Paliativos e Ética dos cuidados pediátricos. Normalmente, a criança doente deve receber toda a atenção e toda a tecnologia médica disponível, tendo em vista encontrar-se na fase inicial do ciclo vital. Contudo, algumas crianças apresentam-se como sofredoras de doenças incuráveis que não as permitirão viver por muito tempo. Ao mesmo tempo em que apresentam crescimento corporal e o desenvolvimento progressivo de habilidades, essas crianças perpassam por um processo crônico de danos à saúde que culminarão com sua morte antes da chegada à vida adulta. Para tais crianças, o uso intensivo da tecnologia médica pode significar não uma esperança de cura, mas um transtorno, um sofrimento a mais em suas vidas.

O avanço da tecnologia biomédica se deu baseado em intervenções invasivas sobre o corpo, usualmente no ambiente tecnocêntrico do hospital (Pessini 1996, 2004). Agulhas, injeções, cateteres, intubação orotraqueal, cirurgias, terapias de substituição de órgãos (ex: diálise) são correntes na prática médica (Pessini 2005, Pinheiro 2011). Embora todo esse avanço tenha permitido suplantar um sem-número de intercorrências e doenças, tais práticas são dolorosas, desconfortáveis e exigem todo um rearranjo da vida social; em outras palavras, trazem dor e sofrimento (Horta 1999, Junges et al. 2010). É um sofrimento por algum período, mas que traz a expectativa ou a chance de alívio em futuro próximo: a tecnologia faz sofrer aqui e agora, com vistas a um alcance futuro (Wanssa 2011).

Mas quando não há a perspectiva de um futuro, em um contexto de terminalidade da vida, as tecnologias de ponta, com esse aspecto de sofrimento e invasão, tornam-se obstinação terapêutica, ou seja, mesmo que a tecnologia exista e esteja disponível, há um limite ético em não indicar para alguns pacientes determinados procedimentos biomédicos, pois, nesses casos, ao invés de tais procedimentos significarem uma expectativa, um alento vindouro, significam apenas uma somatória de dores e sofrimentos que são infligidos a pacientes já em fase terminal (Menezes 2004, Moritz 2005, França et al. 2010). 
As malformações congênitas se expressam em um espectro que vão desde quadros mais leves e sem repercussões à saúde até quadros mais graves que permitem reconhecer um contexto de terminalidade da vida já ao nascimento (Constantino \& Hirschheimer 2005). Ora, se o ciclo vital consiste em nascimento, crescimento e desenvolvimento, por fim a decrepitude e a morte, então crianças portadoras de malformações graves encontram-se em um contexto de terminalidade da vida. É uma situação muito peculiar, pois ao mesmo tempo em que a criança cresce e se desenvolve, as conseqüências das malformações se manifestam, atrasando o desenvolvimento da criança e culminando com sua morte.

Os recém-nascidos portadores de malformações cerebrais encontram-se em uma condição ainda mais complexa. Afinal, a partir do momento em que a vida humana seja indissociável da vida do encéfalo (Lucena et al. 2009), a presença de uma malformação cerebral grave deixa o pequeno paciente em um estado intermediário entre vida e morte (Agamben 2007). Na definição de Kipper (2011), os estados intermediários são condições em que a vida e a morte cerebral de aproximam, como exemplificado no coma profundo e no estado vegetativo persistente. Assim, uma criança portadora de malformações cerebrais graves não apenas se encontra em um contexto de terminalidade de vida como também se encontra em um contexto limítrofe entre vida e morte.

Os cuidados pediátricos são caracterizados pela heteronomia da criança, a qual é representada por um adulto responsável; geralmente os pais (Freitas \& Seidl 2011). A definição de 'cidadão capaz' é um constructo social sobre uma base biológica, ou melhor, sobre o fato biológico do amadurecimento do cérebro (que se dá ao redor dos 14 anos de idade), a sociedade cria seus critérios para definir o cidadão plenamente capaz, o que, no atual momento, ocorre aos 18 anos de idade (Fabbro 1999, Leone 1998). Pode-se dizer que o cidadão capaz é aquele que, frente à sociedade, apresenta um conjunto de atitudes autônomas, ou seja, aquele que, de uma forma ou de outra, consegue se impor perante a sociedade, dentro das regras socialmente estabelecidas (Agamben 2007, Almeida 2010b). Assim, pessoas com lesões estruturais cerebrais podem não ser capazes de decisões autônomas, e com freqüência, a sociedade dispõe de mecanismos de tutela desses indivíduos (Adorno 2009). Mas quais são os limites dessa tutela? Qual a margem de decisão em relação à heteronomia da criança? O tutor tem o direito de exigir e ser atendido em todos os seus desejos? E se a vontade do tutor for, nitidamente, obstinação 
terapêutica? E, ao contrário, se o tutor for negligente, quais e em qual momento procedimentos invasivos devem ser feitos à revelia?

O tratamento de pacientes terminais requer a aplicação de cuidados que têm por paradigma o paciente sem possibilidade de cura (ANCP 2009). A dignidade da vida humana que se esvai deve ser respeitada, assim, a tomada de decisão por tratamentos adequados para a manutenção da vida e mitigação do desconforto sem que haja aumento da dor e do sofrimento é uma questão ética relevante no atendimento de crianças com malformações cerebrais graves (Andorno 2009, Almeida \& Machado 2010). Em cada situação, para cada paciente, podem ocorrer circunstâncias nas quais fica claro o que é obstinação terapêutica e o que é negligência (Villas-Bôas 2005). Mas também, sempre haverá zonas de fronteira, com limites imprecisos, nos quais não fica claro sobre qual o melhor caminho tomar (Souza 2006). É preciso haver mecanismos éticos que diferenciem o não-início de um tratamento com base na obstinação terapêutica de uma atitude de franca negligência profissional (Villas-Bôas 2005, Oliveira 205, Oliveira et al. 2011).

Comparativamente à faixa etária do idoso, as situações de terminalidade da vida no período pediátrico são menos discutidas por serem menos freqüentes na prática clínica pediátrica em geral (Leone 1998, Constantino \& Hirschheimer 2005). Em face da difícil conjuntura que se apresenta para a tomada de decisão médica por recursos terapêuticos para manutenção da sobrevida de crianças com malformações cerebrais, busca-se conhecer, especificamente, quais métodos são por demais invasivos contribuindo para 0 aumentando do quadro de sofrimento e dor, e quais cuidados são considerados indispensáveis e que não podem deixar de ser oferecidos (Almeida 2010b , Almeida \& Machado 2010). 


\section{PARTE I - FUNDAMENTAÇÃO}

1 - Breve sinopse das principais malformações cerebrais

O sistema nervoso central é composto pelo encéfalo e medula espinhal. O encéfalo, por sua vez, pode ser subdividido em: prosencéfalo (telencéfalo e diencéfalo), mesencéfalo e rombencéfalo (metencéfalo - ponte e cerebelo - e mielencéfalo - medula oblonga e bulbo). O bulbo, a ponte e o mesencéfalo formam o tronco encefálico, o qual, entre outras funções, coordena a atividade cardiorrespiratória. Lesões ou malformações nessa região são, portanto, incompatíveis com a vida. O cerebelo coordena principalmente o equilíbrio corporal e a motricidade. O prosencéfalo coordena a motricidade e processa as informações complexas (memória, emoção, etc.). O termo cérebro é impreciso na literatura, ora se referindo apenas ao telencéfalo, ora ao prosencéfalo, ora a todo o encéfalo. No presente trabalho, cérebro será usado como sinônimo de todo o encéfalo (Swaiman et al. 2012, Volpe 2008).

O sistema nervoso central tem origem embrionária na placa neural. A placa neural apresenta elevação das bordas, as quais inicialmente se fundem na região medial do embrião, formando, portanto, dois neuroporos, os quais vão progressivamente se fechando, até que o neuroporo anterior se funde e, cerca de dois dias depois, o neuroporo posterior se fecha, formando o tubo neural. Esse processo encontra-se completo ao redor do $25^{\circ}$ dia de desenvolvimento do embrião. A porção anterior do tubo neural se diferencia em três e depois em cinco vesículas, as quais darão origem aos segmentos do encéfalo.

As malformações do sistema nervoso central apresentam uma freqüência entre 0,5 a 10 casos por 1000 nascidos vivos e em termos de gravidade, segundo Swaiman et al. (2012), ficam atrás apenas das malformações cardíacas. A incidência é desigual em relação ao sexo do bebê, sendo as meninas acometidas na proporção de 2:1 em relação aos meninos. Swaiman et al. (2012) e Volpe (2008) classificam as malformações do sistema nervoso central nos seguintes grandes grupos: a) desordens do fechamento do tubo neural; b) malformações do prosencéfalo; c) malformações de cerebelo e tronco encefálico; d) malformações do córtex cerebral. Além desses grandes grupos, existem 
outras malformações pontuais, tais como cistos aracnóideos, neuromas, cistos epidermóides, etc., cujas seqüelas e conseqüências clínicas costumam ser menos complexas e deletérias.

Mais de uma malformação pode estar presente no mesmo paciente. Essas malformações podem aparecer de forma isolada, combinada, até mesmo apresentação padrões estereotipados relacionados a síndromes genéticas diversas. Evidentemente, quanto mais malformações houver, mais grave é o prognóstico geral de sobrevida e de desenvolvimento intelectual e maior será a necessidade de tratamentos médicos complexos e invasivos.

As desordens do desenvolvimento do fechamento do tubo neural podem ocorrer em qualquer região, tanto nas porções mais superiores (encéfalo) como mais inferiores (medula espinhal). A ocorrência de desordens do tubo neural envolve a inter-relação de pelo menos 200 genes entre si e com o ambiente. A ingestão materna de níveis adequados de ácido fólico reduz a chance de ocorrência dessas malformações, mas não as elimina completamente. A classificação dos problemas do tubo neural é bastante complexa, pois pode refletir problemas tanto em fases mais precoces do desenvolvimento embrionário como momentos mais tardios. As desordens mais precoces, ou seja, de problemas no fechamento do tubo neural, são a anencefalia e a mielomeningocele. Desordens mais tardias incluem a encefalocele, a formação de cistos dermóides, de lipomas, a espinha bífida, a agenesia sacral, dentre outras. Mais comumente, essas malformações mais tardias requerem tratamento médico especializado, mas são compatíveis com a vida e com um bom desempenho intelectual e social (Swaiman et al. 2012, Volpe 2008).

A anencefalia é uma malformação incompatível com a vida extrauterina. Segundo Volpe (2008), há quatro subtipos de anencefalia: a holoacrania, quando não o crânio não se forma acima do forame magno; meroacrania, se pelo menos as estruturas ao redor do forame magno foram minimamente formadas; a atelencefalia-aprosencefalia, na qual os ossos do crânio são formados e a iniencefalia, que é o não-fechamento do tubo neural, com a não-geração de estruturas do encéfalo e medula espinhal. Alguns bebês com atelencefalia sobreviveram até cerca de um ano de idade. 
A mielomeningocele é a malformação mais complexa do sistema nervoso central, no que tange aos aspectos clínicos e terapêuticos. Em algum ponto da medula espinhal, 0 defeito do tubo neural gera uma placa de tecido pouco diferenciado, mas que se conecta com o líquido cefalorraquidiano, gerando hipertensão intracraniana e subsequente hidrocefalia, com acometimento do telencéfalo. A frequência de ocorrência de mielomeningocele tem sido elevada o suficiente para permitir a documentação da história natural dessa malformação: sem tratamento, a mortalidade é de $50 \%$ até os 2 meses de idade, $80 \%$ ao primeiro ano de vida, sendo $90 \%$ aos 10 anos. O mecanismo de morte não é exatamente relacionado ao sistema nervoso, mas sim ao sistema urinário: a espasticidade da musculatura pélvica obstrui o fluxo urinário da bexiga, o que, em médio prazo, gera hidronefrose e morte por insuficiência renal. Além da doença renal, é marcante a deficiência e deformidade dos membros inferiores, com a dependência de cadeiras de roda e de cuidados de ortopedia e de fisioterapia (Swaiman et al. 2012, Volpe 2008).

O tratamento da mielomeningocele é cirúrgico, com a correção ou remoção da estrutura disforme e colocação de derivação ventricular para correção da pressão intracraniana. Volpe descreve que o tratamento desses pacientes esbarra em dilemas éticos sobre obstinação terapêutica. Essas crianças crescem dependentes de tecnologia e de uma série de cuidados gerais, apresentando várias intercorrências clínicas decorrentes da incoordenação do sistema nervoso: infecções urinárias, retenção fecal e urinária, sedentariedade, problemas na coordenação de deglutição, além de crises epilépticas. No geral, a mortalidade acumulada é de $50 \%$ aos 16 anos de idade, e, dentre os adultos, 55\% são dependentes de cadeira de rodas, com severo acometimento intelectual e alta prevalência de epilepsia (30\%) (Swaiman et al. 2012, Volpe 2008).

Segundo Volpe (2008), foram feitos ensaios clínicos baseados em marcadores de bom prognósitco: após o nascimento, os pacientes que apresentassem paralisia severa, perímetro cefálico acima do percentil 95, e/ou outras malformações (cifose ou outras malformações sindrômicas) receberiam apenas cuidados paliativos. Com isso, o grupo de melhor prognóstico, aos 6 anos de vida, apresentou mortalidade de 30\%; mas dentre os sobreviventes, $80 \%$ deambulavam, $90 \%$ não apresentavam sequelas renais e o quociente intelectual ficou acima de 75 em $85 \%$ dos pacientes. O grupo de pior prognóstico, em não sendo tratado, apresentou mortalidade de $80 \%$ aos três meses de idade, dentro da história natural da doneça. Alguns, no entanto, conseguiram sobreviver, mas chegaram aos 10 
anos severamente debilitados e com quociente intelectual abaixo de 75 . Ou seja, os fatores de mau prognóstico não conseguiram detectar, precocemente, os pacientes que, mesmo apresentando esses sinais, teriam ainda assim se beneficiado do tratamento neurocirúrgico, de modo que a tendência terapêutica atual é a da intervenção precoce em todos os pacientes nascidos vivos com mielomeningocele.

A encefalocele é a herniação de parte do conteúdo encefálico pela região média do crânio. Podem ser anteriores, de melhor prognóstico clínico e intelectual, ou posteriores, de curso clínico mais grave. Encefalocele é mais comumente presente em síndromes genéticas, sendo a mais comum é a síndrome de Meckel, na qual além da encefalocele do lobo occipital, ocorrem malformações faciais, polidactilia, malformações renais e genitália ambígua (Swaiman et al. 2012, Volpe 2008).

As desordens de malformação do prosencéfalo são, principalmente: a holoprosencefalia, a agenesia de corpo caloso e a displasia septo-ocular. A holoprosencefalia é a malformação do prosencéfalo, que se mostra em variações que vão desde um desarranjo total do prosencéfalo, até o desarranjo de apenas um dos lobos. Segundo Volpe (2008), a holoprosencefalia pode se manifestar como: a) holoprosencefalia alobar, a forma mais grave, na qual o prosencéfalo é uma estrutura disforme e indiferenciada; b) holoprosencefalia semilobar, na qual rudimentos de estruturas são diferenciadas; c) holoprosencefalia lobar, que abrange formas clinicamente mais leves, nas quais os hemisférios são parcialmente separados e as estruturas mais inferiores são razoavelmente bem diferenciadas. Segundo Volpe (2008), 75\% dos pacientes acometidos de holoprosencefalia apresentam também outras malformações - cardíacas, esqueléticas, gastrintestinais, renais.

A mortalidade geral é de $70 \%$ ao primeiro ano de vida. Ao longo do período de vida, os pacientes sofrem de epilepsias de difícil controle, pneumonias e distúrbios neuroendócrinos relacionados à agenesia ou malformação da hipófise: diabete insípido, défice de hormônio de crescimento, etc. Praticamente todos os pacientes necessitam de alimentação por sonda, dada a incoordenação na deglutição. A expressão clínica após o nascimento é a de hipotonia corporal, com distonia dos membros superiores e espasticidade dos membros inferiores. Com o advento de neuroimagem - tomografia computadorizada e ressonância magnética - tem-se identificado crianças em idade escolar 
com malformações menos graves do prosencéfalo, por exemplo, com formação incompleta de apenas parte de um dos lobos, o que se expressa por retardo mental ou epilepsia de difícil controle. Excetuando-se os casos mais leves, os pacientes apresentam reduzido desenvolvimento psicomotor, comportando-se funcionalmente como pacientes em estado de coma persistente (Swaiman et al. 2012, Volpe 2008).

A agenesia de corpo caloso mais frequentemente é parte de um conjunto sindrômico de outras malformações do encéfalo, o que se associa a grande heterogeneidade de manifestações clínicas. Contudo, a agenesia ou malformação do corpo caloso, isoladamente, apresenta vários desfechos clínicos: os mais leves são imperceptíveis, os moderados apresentam algum acometimento intelectual, com dificuldades de ajustamento social e comportamento autista-símile, os mais graves se apresentam com epilepsias de difícil controle e grave acometimento intelectual (Swaiman et al. 2012, Volpe 2008).

A displasia septo-ocular é um grupo diversificado de malformações que envolvem o nervo óptico, a hipófise, o septo pelúcido ou outras estruturas do prosencéfalo. Em seu conjunto, são compatíveis com uma vida social minimamente razoável, mas podem se manifestar por quadros clínicos complexos, por vezes graves (Swaiman et al. 2012, Volpe 2008).

No geral, a disgenesia de cerebelo se associa a desordens do equilíbrio e do movimento corporal, mas, isoladamente, são compatíveis com vida social. Dentre as malformações de cerebelo e tronco encefálico, a mais comum é a malformação de DandyWalker, na qual além de malformação cerebelar, existe alargamento do quarto ventrículo, e a síndrome de Chiari, na qual a malformação cerebelar se associa a outras malformações do prosencéfalo (Swaiman et al. 2012, Volpe 2008).

As malformações do córtex cerebral podem se manifestar de forma bastante grave: a lisencefalia é a hipoplasia ou mesmo a não-formação dos giros corticais. As crianças acometidas manifestam logo ao período neonatal de hipotonia, incoordenação de deglutição, crises convulsivas, com mortalidade de $50 \%$ no primeiro ano de vida. O suporte nutricional por sondas é essencial no tratamento desses pacientes, mas, comumente, por volta dos três anos de idade, inicia-se uma série de pneumonias aspirativas, de modo que a mortalidade acumulada aos 10 anos de vida é de cerca de $90 \%$. Tanto mais grave será o 
quadro conforme a associação com outras malformações (Swaiman et al. 2012, Volpe 2008).

Outras malformações do córtex cerebral são: a esquizencefalia, que é a formação de fendas unindo o córtex cerebral até o epêndima, displasias corticais focais, dentre outras. São mais raras, e em uma revisão de 11 crianças de 2 a 14 anos diagnosticadas com esquizencefalia, 1 teve um desenvolvimento psicomotor normal, 0 restante apresentava paralisia e/ou convulsões (Amaral et al. 2001).

Em conclusão, esse breve panorama aqui apresentado não esgota as malformações cerebrais já descritas. Em seu conjunto, há desde malformações clinicamente imperceptíveis até graves dismorfismos claramente incompatíveis com a vida. Em seu conjunto, as malformações do sistema nervoso não são por si a causa de morte, mas sim a lesão de outros órgãos vitais em decorrência da incoordenação motora - pulmões (pneumonia aspirativa), rins, pele (escaras de decúbito). Essas intercorrências clínicas não costumam ser fatais logo à primeira ocorrência, mas vão pouco a pouco promovendo um declínio orgânico generalizado até advir o óbito. Assim, os conflitos bioéticos e a obstinação terapêutica se evidenciam nos casos de gravidade intermediária.

\section{2 - Ética dos Cuidados Paliativos e da Limitação Terapêutica}

\section{Introdução}

Paliação significa o ato de paliar (ANCP 2006). Paliar, conforme o dicionário, significa atenuar, aliviar, mas também apresenta a conotação de resolução de forma incompleta ou temporária. No dicionário de inglês, palliative significa aliviar, mas sem curar. Dessa forma, a compreensão para o presente debate deve considerar que paliação é toda medida terapêutica que resulte em alívio do sofrimento, quer seja de forma curativa, quer seja de forma temporária. A Organização Mundial da Saúde definiu, em 2002, Cuidados Paliativos como a abordagem terapêutica que promove qualidade de vida de 
pacientes e seus familiares diante de doenças que ameaçam a continuidade da vida, através de prevenção e alívio do sofrimento (ANCP 2006).

Ainda, segundo a Academia Nacional de Cuidados Paliativos (2006) e também o Cremesp (2008), os Cuidados Paliativos são cuidados prestados por equipes necessariamente multiprofissionais, não apenas médicos, que adotam um modelo terapêutico cujo foco é a melhora na qualidade de vida do paciente, mediante o controle dos diversos sintomas responsáveis pelo sofrimento físico, psíquico, espiritual e social. O Cremesp (2008) traz os conceitos de interface intrínseca para designar os profissionais integrantes da equipe de Cuidados Paliativos e interface extrínseca para descrever o suporte de outros profissionais e especialidades para a resolução de problemas, tais como: médicos anestesistas para a realização de bloqueios anestésicos e instalação de analgesia controlada pelo paciente; cirurgiões para a realização de ostomias, toracocentese, paracentes, debridamento de feridas, clínicos e enfermeiros especialistas ou experientes na doença de base do paciente (neoplasia, neuropatias, pneumopatias, cardiopatias, etc.).

Os Cuidados Paliativos podem ocorrer tanto em todas as alas do ambiente hospitalar - enfermarias, UTIs, ambulatórios - como também no próprio ambiente doméstico, inclusive mediante visitação domiciliar, e são indicados independentemente de faixa etária ou de possibilidade de cura, sendo indicados a todos os pacientes portadores de doenças crônicas com potencial de encurtar a vida, podendo ocorrer conjuntamente com as terapias destinadas à cura e ao prolongamento da vida (Moritz et al. 2011). O foco da atenção não é a doença a ser controlada, mas o paciente com direito à informação e autonomia para as decisões a respeito de seu tratamento. A prática adequada dos Cuidados Paliativos preconiza atenção individualizada ao paciente e a seus familiares, em uma busca pelas melhores condutas para o controle de seus sintomas.

A Academia Nacional de Cuidados Paliativos (2006) e a Fondazione Maruzza Lefebvre D'Ovidio Onlus (Capelas 2009) denunciam o equívoco, comum, que os Cuidados Paliativos se resumem aos cuidados dispensados ao final da vida. Ao contrário, a concomitância da abordagem paliativa com o tratamento curativo é viável. Ações paliativas desenvolvidas desde a fase do diagnóstico da doença podem ser desenvolvidas por todo profissional de saúde, ou seja, não é preciso uma equipe especializada. Conforme a doença for progredindo e o tratamento curativo não apresentar mais a possibilidade de 
controle ou cura, os Cuidados Paliativos crescem em significado, surgindo como uma necessidade na fase final. Nesse ponto, a qualidade do atendimento prestado pode ser significativamente melhorada se houver uma equipe de profissionais treinados e com experiência não apenas no controle dos sintomas, mas, sobretudo, na comunicação e no diálogo com o paciente e seus familiares.

O Cremesp (2008) conjuntamente com a $\operatorname{ANCP}(2006,2009)$, sugerem que se evite o uso do termo 'paciente terminal', por ser considerado estigmatizante e gerador de confusões, pois não há consenso na literatura sobre o que exatamente esse termo significa: se a simples existência de doença incurável, mesmo que em fase inicial; se o período de falha total do tratamento; se o período relativo aos últimos seis meses de vida; se o período relativo às últimas semanas ou últimas horas de vida. Em consenso, o grupo de trabalho recomenda que se adote a terminologia de 'paciente elegível para cuidados paliativos', definida como todo paciente portador de doença crônica, evolutiva e progressiva, com prognóstico de vida estimado para poucos meses ou anos. O mesmo grupo reconhece que há doenças crônicas de evolução muito lenta, para as quais a terminalidade pode ser definida como um perfil funcional menor que $40 \%$ da escala de Karnofsky (ANCP 2009). A terminologia de 'paciente em processo de morte' se refere ao paciente que apresente rápida deterioração da doença. $E$ por fase final de vida entendemse os últimos dias ou então as últimas 48 horas de vida. De forma semelhante, dada a cronicidade das doenças, a terminologia a ser empregada não é exatamente 'possibilidade de cura', mas a 'possibilidade de controle/mudança de curso da doença'.

\section{Histórico}

A história dos Cuidados Paliativos se confunde com o termo inglês hospice, sem tradução direta precisa para o português (Pessini 2001). Na Europa, na Idade Média, hospices eram albergues, geralmente posicionados em áreas de intenso tráfego de peregrinos e viajantes, e que davam assistência, a princípio gratuita ou por caridade, àqueles que se viam enfermos. O relato mais antigo é o do Hospice do Porto de Roma, no século V. A Idade Média viu surgir na Europa vários hospices, mantidos por ordens religiosas. A princípio, esses estabelecimentos surgiram ao longo de trajetórias de 
peregrinação, como o caminho de Santiago de Compostela. Ressalte-se que a ocorrência de óbitos era comum nesses locais (Cremesp 2008).

A partir do século $\mathrm{XVII}$, além de estabelecimento para peregrinos, surgiram também abrigos para órfãos, pobres, doentes, mantidos por instituições religiosas e comumente contavam com financiamento governamental e serviam também como locais de suporte social. A partir do século XIX, os hospices começaram a ter características dos hospitais modernos, ou seja, a se voltarem mais precisamente para o cuidado dos doentes, com alas destinadas aos doentes de tuberculose e alguns com câncer. O cuidado a esses doentes era essencialmente voltado para o cuidado espiritual, controle de dor e suporte social (alimentação, hospedagem). Exemplos desses hospices foram, em 1805, o St Joseph Hospice, na Grã-Bretanha; em 1842, o Hospice de Lyon, destinado exclusivamente a pessoas em franca terminalidade de vida; em 1846 em Dublin, aberto pelas Irmãs Irlandesas da Caridade; em 1885 o St. Columba, criado em Londres; em 1893, também em Londres, o St Luke's, inaugurado pelo médico Howard Barret (Cremesp 2008, ANCP 2009).

Essencialmente, até o avanço médico surgido ao redor da década de 1940, a morte era essencialmente um evento domiciliar, assistido principalmente por clérigos; somente uma pequena elite dispunha de supervisão médica em seus últimos momentos. A ida para um hospice era um ato de caridade para com a população pobre (Foucault 1963, Pessini 2001).

Com todo o avanço da tecnologia médica, e dos fatores sociais em saúde, a expectativa de vida da população como um todo aumentou significativamente e a sobrevida dos doentes foi incrementada. O que no século XIX era descrito como sinal de morte iminente - tal como a ausência de pulso, a redução da respiração (bradipneia), dentre oturos - foi entendido e abordado por ventilação mecânica, drogas vasoativas e toda uma alta tecnologia que possibilita monitoramento contínuo desses pacientes. Assim que ao final da década de 1960 é que a ausência de função do tronco encefálico ficou definida como o derradeiro critério de morte (ANCP 2009).

Em poucas décadas, a morte, que era domiciliar, passou a ser um evento essencialmente hospitalar, e, portanto, medicalizado. O esforço para prolongar a vida a todo custo tornou-se uma obsessão científica, já que o tempo de sobrevida é facilmente possível de ser mensurado, mas não a qualidade de vida. Dificilmente a equipe médica diria que 'ajudou o paciente Fulano a morrer bem'. Quando a evolução da doença 
derrotava todas as possibilidades terapêuticas, a equipe médica nada mais fazia para promover a cura (Pessini \& Bertachini 2006).

Os Cuidados Paliativos surgiram, portanto, em uma resposta à hipermedicalização do processo de morte. Em 1967, na Inglaterra, Cicely Saunders, médica, enfermeira e assistente social, fundou o St. Christopher Hospice, dedicado ao cuidado e alívio da dor dos doentes terminais de câncer. Cicely Saunders dedicou boa parte de sua carreira à pesquisa nesse campo, tendo criado o conceito de dor total, em referência à morte de pacientes terminais isolados em hospitais, longe de familiares, submetidos a procedimentos médicos agressivos e dolorosos que apenas prolongavam a agonia do paciente sem lhes trazer benefícios significativos (Cremesp 2008, ANCP 2009). A estrutura do St. Christopher Hospice não apenas assitia aos pacientes, mas tinha esforços de ensino e pesquisa, tendo recebido estudantes de vários países. Na década de 1970, nos Estados Unidos, a psiquiatra de origem suíça Elizabeth Klüber-Ross tomou conhecimento do movimento e fundou em 1975 o primeiro hospice norte-americano. É dela o modelo das cinco fases do luto: negação, raiva, negociação, depressão e aceitação. Em 1982, o sistema legislativo norte-americano validou o Hospice Care como sendo reembolsável (Cremesp 2008).

Dessa forma, o conceito moderno dos Cuidados Paliativos surgiu em um período de extrema medicalização do paciente terminal: não bastasse o sofrimento inerente à própria doença, um exagero de procedimentos e tratamentos agravava a condição degradante do paciente. Os Cuidados Paliativos não foram uma negação total ao processo de medicalização da morte, mas sim uma adaptação, uma racionalização desse processo. Como todo movimento social, foi preciso que os Cuidados Paliativos criassem uma linguagem simbólica sobre o processo de morte que orientasse sobre as condutas médicas a serem tomadas.

Em 1982, o Comitê de Câncer da Organização Mundial da Saúde criou um grupo de trabalho para definir políticas para o alívio da dor e dos cuidados do tipo hospice que pudessem ser recomendáveis a todos os países. A expressão 'Cuidados Paliativos' passou a ser adotada, em função das dificuldades de tradução do termo 'Hospice' em vários idiomas. Em 1986, a OMS publicou sua primeira definição de Cuidados Paliativos: "Cuidado ativo e total para pacientes cuja doença não é responsiva a tratametno de cura". Em 1987, o primeiro país a reconhecer a medicina paliativa como especialidade da área médica foi o Reino Unido. 
Em 2002, a OMS reviu a definição do conceito com o objetivo de ampliar o conceito e torná-lo aplicável a todas as doenças, o mais precocemente possível: "Cuidados Paliativos é a abordagem que promove a qualidade de vida de pacientes e seus familiares diante de doenças que ameacem a continuidade da vida, através de prevenção e alívio do sofrimento". Ainda em 2002, a OMS publicou dois documentos importatnes: The Solid Facts of Palliative Care e Better Care of the Elderly; ambos recomendando os Cuidados Paliativos como estratégia de ação em sistemas nacionais de saúde. Ou seja, os Cuidados Paliativos saíram da esfera do câncer e adentraram outras áreas do conhecimento, como pediatria, geriatria, HIV/Aids, doenças crônicas, etc.

$\mathrm{Na}$ Inglaterra existem hoje por volta de 470 hospices e nos Estados Unidos 0 número ultrapassa 5.000. Na Europa, Canadá, Austrália e Japão, eles estão em expansão. No Brasil existem diversos serviços cadastrados como prestadores de Cuidados Paliativos, com características próprias e peculiares e que nasceram, em sua maioria, de serviços de dor. A Hospedaria de Cuidados Paliativos do Hospital do Servidor Público Municipal de São Paulo foi um serviço pioneiro em nosso país, principalmente no modelo de instalações e funcionamento (ANCP 2006).

Em 2006, o Documento intitulado "Mapping levels of Palliative Care Development: a Global View", elaborado pelo International Observatory on End of Life Care - IOELC - da Universidade de Lancaster, no Reino Unido, identificou a presença e complexidade de serviços de Cuidados Paliativos nestes países e os classificou em quatro níveis distintos: Grupo IV (35 países) - possuem serviços de Cuidados Paliativos e uma política estruturada de provisão destes serviços; Grupo III (80 países) - presença de serviços isolados de Cuidados Paliativos, entre os quais se encontra o Brasil; Grupo II (41 países) - não possuem serviços estruturados, mas têm iniciativas, no sentido de formarem profissionais e equipes; Grupo I (79 países) - onde não há registro de nenhuma iniciativa de Cuidados Paliativos (ANCP 2006).

O IOELC identificou no Brasil 14 serviços, sendo que na participação em congressos, existem 40 serviços implantados ou em implantação. Normatizações nacionais incluem: a) a criação de uma Câmara Técnica em Controle da Dor e Cuidados Paliativos, criada pela portaria ํo 3.150 do Ministério da Saúde em 12 de dezembro de 2006; b) a criação de uma Câmara Técnica sobre a Terminalidade da Vida no Conselho Federal de Medicina, que em 2006, aprovou a resolução 1.805/06 que dispõe sobre a ortotanásia no Brasil; c) a proposta de formação de um Comitê de Medicina Paliativa na Associação 
Médica Brasileira - AMB, com intenção de propor o reconhecimento da medicina paliativa como área de atuação do médico numa equipe de Cuidados Paliativos e d) a existência da Academia Nacional de Cuidados Paliativos - ANCP, associação de profissionais atuantes na área de Cuidados Paliativos e que participa ativamente de todas estas instâncias políticas.

Em conclusão, estas iniciativas sinalizam um futuro próximo em que os Cuidados Paliativos serão parte integrante e essencial da assistência à saúde no âmbito do Sistema Único de Saúde e, futuramente, do Sistema de Saúde Suplementar.

\section{Futilidade Terapêutica}

Conforme Biondo et al. (2009), futilidade terapêutica é definida como a prática médica de adotar tratamentos invasivos que apenas prolongam a agonia, a dor e a angústia de um paciente terminal. Diniz (2006) traz as palavras dos pais de uma criança severamente doente que distinguiram entre 'tratamento doloroso' e 'tortura médica': se um tratamento apresenta potencial de cura ou de melhoria, é um tratamento doloroso. Mas na ausência de perspectiva de melhora, Diniz (2006) considera, portanto, que 'futilidade terapêutica' ou 'obstinação terapêutica' sejam apenas eufemismos para 'tortura'. Kovács (2004) traz a etimologia do vocábulo 'fútil', o qual se origina da palavra latina futilis, que significa furado, aquilo que deixa escapar o que contém. O conceito de futilidade terapêutica está, conforme Pessini (2001) e também Simone (2000), relacionado aos conceitos de eutanásia, distanásia, mistanásia, obstinação terapêutica e cuidados paliativos. Segundo Pessini (2001), esses conceitos devem ser esclarecidos quanto às semelhanças e diferenças, para que não haja confusão nos debates bioéticos que norteiam conclusões e decisões clínicas. Para Biondo et al. (2009), distanásia, tratamento fútil, tratamento inútil e obstinação terapêutica são sinônimos. Por sua vez, Floriani \& Schramm (2008) concordam em parte, pois se por um lado reconhecem que há nuances no significado de cada um dos termos, por outro concluem que essas pequenas diferenças não apresentam impacto relevante no contexto clínico. Em comum, não se fala nesses conceitos fora de um contexto médico-hospitalar, ou seja, são debates bioéticos que rondam intervenções médicas em situações institucionais. Para Pessini (2001) e também 
para Porta I Sales (2000), existem grupos de pacientes particularmente expostos à futilidade terapêutica: coma persistente ou estado vegetativo persistente; fase terminal de neoplasias e pacientes dependentes de forma permanente de cuidados de terapia intensiva, ou seja, os pacientes crônicos, de doenças degenerativas. Porta I Sales (2000) diferenciam esse grupo de pacientes daqueles que sofrem, repentinamente, de acidentes de tráfego, infecções agudas, violência, e que podem evoluir de forma grave, para quem o investimento maciço de tecnologias de cura não constitui obstinação terapêutica.

O conceito de futilidade terapêutica, segundo Alonso (2012) e também Taboada (2000), está relacionado ao valor de morte digna, boa morte e ortotanásia. Ou seja, idealmente, haveria uma forma de bem morrer que estaria sendo impedida pela prática recorrente da obstinação terapêutica, pois, conforme Nunes (2009), a hipermedicalização da morte é o caminho mais fácil, com relação impessoal com o paciente, estudos diagnósticos excessivos e agressivos e terapias de alta tecnologia invasivas e ineficazes. $\mathrm{Na}$ confrontação desses dilemas éticos surgem os termos de distanásia, mistanásia e ortotanásia. Enquanto o termo distanásia é sinônimo de obstinação terapêutica, a ortotanásia se encaixa dentro do valor de boa morte e morte na hora e no momento correto. Siqueira-Batista \& Schramm (2005) questionam se a ortotánasia, a morte no tempo certo, seria viável em um contexto no qual há possibilidades quase inesgotáveis de prolongamento da vida. Em resumo, Siqueira levanta que o dilema ético acerca da futilidade terapêutica, é reconhecer o momento de não se usar toda a tecnologia disponível. Simone (2000), além disso, descreve o conceito de mistanásia para se referir ao simples não-tratamento de pacientes terminais, o que também se constitui em uma postura extremista, exagerada e eticamente inaceitável.

Nesse sentido, Pessini (2001) fundamenta que não se pode confundir tratamento fútil com futilidade da vida. Nunes (2009) ressalta que o objetivo de todo cuidado transcende a preservar a saúde e na verdade é conservar a dignidade da pessoa humana. Assim, existem limites aos tratamentos porque estes, sobretudo, teriam que fazer sentido para quem os recebe. A idéia de boa morte está presente também nas discussões sobre eutanásia, que nas palavras de Pessini (2001) e de Floriani \& Schramm (2008) frequentemente distorcem e confundem os debates sobre futilidade terapêutica e decisões de limitação terapêutica. Siqueira-Batista \& Schramm (2005) notam que há um limite borrado e impreciso entre o que seria uma morte por não-intervenção e o que seria 
ortotanásia. Realmente, Taboada (2000) traz o conceito presente na literatura que misturaria a limitação terapêutica à eutanásia, chamando-a de eutanásia passiva. E Twycross (2000) traz o conceito de eutanásia indireta para se referir, no contexto do tratamento clínico de pacientes de câncer terminal, ao uso maciço de morfina no combate à dor, mas que como efeito colateral pode desencadear uma parada respiratória e a consequente morte. Esses mesmos autores, embora tragam esses conceitos à tona, imediatamente os questionam, mostrando que trata-se de confusão de idéias e valores.

Para esclarecer os limites e diferenças entre eutanásia e limitação terapêutica, é importante considerar as conclusões de Pessini (2001) e também de Floriani \& Schramm (2008) que a eutanásia e a distanásia são dois lados de uma mesma moeda, relacionada à busca e ao desejo inerente do ser humano em controlar os processos da natureza. No caso, as ciências médicas, que, objetivando preservar a vida e aliviar o sofrimento, foram além de descrever o curso natural das doenças, tendo gerado tecnologias eficazes de cura, de modo que simplesmente deixar as doenças seguirem seu curso natural já não é aceitável eticamente. O caminho continua sendo o de lutar contra, o de tentar controlar as doenças e os processos biológicos inerentes ao ser humano. Entretanto, uma vez que não seja factível ao homem evitar a morte, os objetivos de preservar a vida e aliviar 0 sofrimento podem se tornar conflitantes. Diante de uma pessoa em fase terminal de vida, a eutanásia simboliza o desejo humano de controlar a morte, determinando que esta se dê aqui, agora, sem dor, sob anestesia e mediante tais e quais procedimentos. A obstinação terapêutica representa o desejo de postergar a morte a todo custo, mesmo que por breves instantes e ainda que isso provoque ainda mais dor e sofrimento ao paciente, que passa a sofrer da chamada dor total - física, mental, espiritual, social, conceito criado por Cecily Saunders para se referir a esses pacientes. Portanto, embora eutanásia e distanásia apresentem raízes em comum, na conclusão de Pessini (2001) são completamente distintas e se colocam em lados antagônicos.

Burlà e Py (2005), rediscutindo o conceito de boa morte ou ortotanásia, chegam à conclusão que não existe exatamente uma morte digna, uma vez que a morte é o evento inexorável que mais deixa o ser humano indignado e cuja lembrança é capaz de desestabilizar a estrutura psíquica de um indivíduo. Assim, a morte é, por essência, indigna, e no arquétipo humano nunca ocorre na hora certa. Rachel de Queiroz percebera, em suas crônicas escritas à época de seu final de vida, que ninguém morre em plena 
saúde, mas sim em situações de dor, cansaço, mal-estar, penúria. Dessa forma, segundo Taboada (2000), embora idealmente as pessoas queiram morrer em casa, o sofrimento que antecede a morte as empurra para o hospital, onde é possível haver suporte ao sofrimento. Dessa forma, Taboada (2000) traz a síntese dos conceitos de boa morte e obstinação terapêutica: a partir do momento em que a morte se tornou um evento medicalizado, surgem questões técnicas, éticas e também jurídicas de como deve ser a assistência a pacientes terminais. Ou seja, não se trata exatamente de prover uma boa morte, mas de se fazer uma boa gestão médica de final de vida.

Márquez (2009) ressalta que o impacto sobre os valores, sentimentos, espiritualidade e decisões clínicas varia enormemente conforme o indivíduo terminal seja recém-nascido, criança, adulto jovem ou idoso. Segundo Pessini (2001), Biondo (2009) e Simone (2000), há rejeição unânime à obstinação terapêutica e, mais ainda, à mistanásia. Entretanto, a tradução desse conceito na prática clínica de forma rotineira necessita de instrumentos específicos, dados estatísticos e diretrizes consensuais de quando um tratamento mais prejudica do que beneficia um determinado paciente e que portanto não deve ser utilizado ou mesmo deve ser interrompido. No que tange à eutanásia, Taboada (2000) lista as razões mais frequentes para sua solicitação: medo, desgaste emocional, depressão, dor excruciante, desejo de controlar a morte. Tanto Taboada (2000) como Twycross (2000) levantam que há muita oposição por parte de médicos e enfermeiros à eutanásia, tendo em vista que, na prática clínica cotidiana, a grande maioria dos pacientes que solicitam eutanásia mudam de idéia após provimento adequado de cuidados paliativos e alívio dos sintomas. Portanto, a boa gestão dos pacientes terminais implica na realização de tratamento adequados e na não-realização de terapias cujos efeitos colaterais suplantem os efeitos benéficos. Entretanto, Taboada (2000) ressalta que, embora um cálculo rápido da proporcionalidade possa ser feito, a decisão de limitação terapêutica não se restringe a uma simples fórmula, tendo que ser o resultado de um diálogo franco e aberto para com os pacientes e seus responsáveis.

Segundo Pessini (2001), essa lacuna no desenvolvimento da prática clínica concernente ao paciente terminal decorre de um processo histórico no qual, a morte em hospitais era sinal de pobreza, mendicância, indigência, mas que o avanço tecnológico surgido a partir do século XIX fez com que essa situação se invertesse: o hospital passou a ser o local tanto de nascimento quanto de morte; não nascer e não morrer em um hospital 
significam pobreza e desamparo. A morte, na visão de Foucault (1963), deixa de ser um evento familiar para se tornar uma questão de saúde pública a ser gerenciada pelo biopoder dos Estados, ou seja, haver leitos hospitalares (entendidos aqui como o somatório gerencial do espaço físico e dos recursos humanos) para o atendimento aos pacientes terminais. Ou seja, antigamente, o que era um local para cuidados finais e morte tornou-se o principal local de cura e reabilitação, porém, terminou, na verdade, por se tornar responsável ao mesmo tempo por eventos antagônicos e mutuamente excludentes o da cura e o da morte. Ainda, conforme bem lembra Simone (2000), a medicalização da morte surge em um contexto de rápidas e profundas transformações tecnológicas, com o surgimento de múltiplos recursos que substituem funções vitais, mas cujo conhecimento sobre os reais limites e extensões leva tempo para ser adquirido, e nesse ínterim novas tecnologias surgem se aprimoram. Ou seja, é um tempo historicamente muito curto para que paradigmas milenares que nortearam a evolução da medicina tenham se adaptado a novos desafios éticos frente ao progresso tecnológico.

Segundo a Moritz et al. (2011), mundo afora, os pacientes terminais acumulam-se nos hospitais, recebendo tratamentos intensivos e inadequados, focados na tentativa de recuperação, ignorando o sofrimento do paciente e incapazes de tratar os sintomas mais prevalentes, como dor, desconforto, náusea. Pessini (2001) observa que o progresso tecnológico tem desenvolvido a tendência de tornar absoluta a dimensão da cura: as novas possibilidades terapêuticas, impensáveis até há pouco mais de décadas, expande a noção que a prática médica seja puramente técnica, com um conjunto de tecnologias eticamente neutras e limitadas apenas por questões de convicção pessoal do paciente ou mesmo a capacidade financeira do indivíduo. No entanto, o tratamento médico apresenta significados distintos conforme o paciente seja um recém-nascido prematuro ou um idoso centenário. Também, a boa saúde é uma qualidade muito peculiar: é o bem mais precioso da vida, mas que quando presente é invisível e silencioso.

Conforme Kovacs (2004), o próprio desenvolvimento da terapêutica não conseguiu eliminar a questão do duplo efeito. O duplo efeito é a percepção que todo tratamento apresenta um aspecto positivo (ou desejável) e um aspecto negativo (ou indesejável). Esse aspecto intrínseco da terapêutica vem de desde a época hipocrática, como evidenciado pelo fato que na etimologia da palavra 'fármaco' está o radical grego pharmakón, que significa tanto 'remédio’ como ‘veneno'. Ou seja, intrinsecamente, o mesmo que mata é o 
que pode curar, e vice-versa. Realmente, não apenas os fármacos, mas toda a tecnologia médica desenvolvida apresenta um potencial de cura, mas ao mesmo tempo, efeitos indesejáveis: são invasivas, dolorosas, deformantes, restritivas; restringem o paciente ao leito do hospital, exigem cuidados e manipulações especializadas, etc. Portanto, a decisão terapêutica de iniciar ou não um tratamento com base em seu duplo efeito não é uma discussão meramente técnica, mas sim um questionamento ético, que ao lado do conhecimento técnico deve agregar o valor da dignidade humana do paciente. Ou seja, torna-se necessária uma postura que não se deixe levar pela tecnolatria e cultive o equilíbrio entre a tecnologia e o humanismo na abordagem a pacientes terminais.

Como consequência conceitual do duplo efeito acerca da futilidade terapêutica, temse que nenhum tratamento por si só é fútil; a futilidade somente se concretiza quando o tratamento é empregado a algum paciente. A futilidade é um atributo de valor relativo, ligado aos objetivos do tratamento. Portanto, definir quais são os objetivos do tratamento de um paciente - se primordialmente cura ou se principalmente alívio - é o que embasa as discussões sobre o que constitui ou não um tratamento fútil. Como exemplo, Kovacs (2004) exemplifica que o procedimento de traqueotomia pode ser considerado tratamento essencial para uma pessoa com doença irreversível, por ser uma medida de alívio, mas submeter a uma hemodiálise essa mesma pessoa pode ser interpretado como medida desproporcional, uma vez que a diálise traz seus desconfortos e limitações e em um contexto de terminalidade apenas aumentaria o sofrimento do paciente, sem que houvesse uma perspectiva de melhora geral de seu quadro clínico. Ou seja, um mesmo procedimento pode ser fútil em termos de cura, mas essencial em termos de alívio do sofrimento.

Embora a futilidade seja um julgamento de valor, portanto, um julgamento moral, este deve estar minimamente embasado em critérios técnicos e estatísticos. Calderón et al. (2010) descrevem algumas propostas presentes na literatura para o embasamento técnico do que seja futilidade: ora um tratamento pode ser fútil se não tiver funcionado nos últimos cem casos em que foi aplicado; ora se houver uma chance inferior a $5 \%$ de sucesso da intervenção; ora se a chance for inferior a $3 \%$. Ou seja, mesmo do ponto de vista estritamente técnico, essas definições estabelecem limites arbitrários. Ainda assim, ao definirem limites, esclarecem situações nas quais, tecnicamente, a futilidade não estaria presente: os limites de 1,3 ou $5 \%$ citados anteriormente delimitam, em conjunto, um limite 
de $10 \%$ que não pode ser considerado, tecnicamente, como fútil. Assim, a futilidade não deve ser um julgamento unicamente baseado na baixa probabilidade de sucesso de um tratamento, pois mesmo uma baixa probabilidade é melhor do que zero.

Também, segundo Nunes (2008), a Associação Portuguesa de Cuidados Paliativos define por doente terminal aquele cuja vida seja esperada, estatisticamente, para durar três a seis meses. Novamente, esse intervalo de tempo não representa uma decisão puramente técnica: por que três a seis meses e não mais ou menos? Esse período é considerado para qualquer fase da vida (neonato, criança, adulto, idoso)? De todo modo, esse documento cita que esse intervalo é um dado empírico que não deve ser tido de modo absoluto, mas que pode guiar adequadamente a grande maioria dos pacientes terminais. Inclusive, uma leitura invertida pode, inclusive, esclarecer o que não seja um paciente terminal: aquele com expectativa de vida maior do que seis meses caso os tratamentos disponíveis sejam adotados. Assim, por exemplo, o uso de uma sonda de alimentação para pacientes em estado vegetativo persistente pode representar uma medida que prolonga a vida para muito além de seis meses. Dessa forma, já existe algum balizamento para responder se um tratamento/suporte crônico é ou não fútil: se com o tratamento, houver perspectiva de vida para além de seis meses, então, não é um tratamento fútil. Se não o fizer, então a hipótese de futilidade pode ser aventada.

Sob outro ângulo, a questão da futilidade está embasada na avaliação de prognóstico. O futuro não pode ser previsto, mas existem avaliações baseadas em escalas, criadas com base em histórico de estatísticas de casos semelhantes. Há sinais e sintomas que podem estimar a situação fisiológica do paciente terminal, mas ainda assim o julgamento clínico é muito complexo. Como exemplo, conforme a ANCP (2006), para pacientes com câncer foi desenvolvida a escala de Karnofsky, na qual um índice de 50\% já indica situação de terminalidade. Em 2001, a Escala Qualitativa de Desempenho foi desenvolvida para medir a condição clínica geral de um paciente adulto. Além dessas, escalas específicas para doenças crônicas comuns têm sido desenvolvidas para insuficiência cardíaca, doença pulmonar obstrutiva crônica, esclerose lateral amiotrófica, demência, dentre outras.

Um grande perigo observado por Marta et al. (2010) é que, na prática de se avaliar o prognóstico de sobrevida de um paciente é determinar a morte social antes da morte física. 
O risco é que, uma vez estabelecido um prognóstico de morte iminente, corre-se o risco de subestimar as necessidades reais do paciente e negligenciar medidas de conforto real. $\mathrm{Na}$ verdade, Christakis (2000) demonstrou que o prognóstico da equipe médica tende a ser enviesado no sentido de otimismo, o que, no contexto de pacientes terminais representa mais a tendência ao tratamento, inclusive ao sobretratamento, do que propriamente à limitação terapêutica.

No cerne do debate sobre obstinação terapêutica e limitação de procedimentos está a delegação do poder de decisão: quem o tem, como deve ser exercido, quais são seus limites e seus desvios. É, também, uma questão de qual autoridade a sociedade outorga aos profissionais médicos, a quem cabe tanto a decisão como a responsabilidade jurídica da consequência de seus atos (Pessini 2001). Para fins de decisão clínica, o fundamento da futilidade terapêutica deve responder a pelo menos três quesitos: a) quais são os critérios para avaliar os tratamentos; b) quem são as pessoas qualificadas para julgar se os tratamentos são desejáveis ou apropriados e c) quais decisões e ações derivam do julgamento feito.

Calderón et al. (2010), Nunes (2008) concordam em linhas gerais sobre as gradações de limitação terapêutica. Se os efeitos deletérios de um tratamento se mostram desproporcionados em relação aos benefícios obtidos, este deve ser interrompido. Se a expectativa de malefício de um tratamento superar de modo desproporcional as chances de benefícios, então este não deve ser iniciado. Se um tratamento traz conforto e se o paciente está bem adaptado a este, não se admite sua interrupção. Mas, em termos conceituais, os autores discutem as situações intermediárias, ou seja, aquelas nas quais o tratamento oferece algum benefício, mas às custas de sofrimento. Essas situações intermediárias devem ser resolvidas com base essencialmente no diálogo com os pacientes e seus responsáveis. A suspensão de um tratamento considerado fútil deve necessariamente contrabalançar o custo e o dano, ou seja, a opção de não tratar deve ser considerada como sendo do melhor interesse para o paciente, tendo-se em vista o dano provocado pelo duplo-efeito e a baixa probabilidade de sucesso do tratamento.

Até há poucas décadas, a prática médica era caracterizada por um paternalismo exacerbado, ou seja, a equipe médica era a única responsável por determinar a utilidade e a indicação dos tratamentos, muitas vezes à revelia do paciente e até mesmo omitindo-lhe 
informações, usualmente sob o discurso que 'é melhor que o paciente não saiba de nada, para não se preocupar ainda mais e sofrer desgaste emocional' (Glaser \& Strauss 1965). Essa postura paternalista tem se modificado radicalmente, pela evolução do contexto clínico-social.

Primeiramente, o paternalismo é considerado até mesmo deletério em seu propósito de, eventualmente, proteger o paciente de novas preocupações, tendo-se em vista o fundamento filosófico budista para o qual a superação do sofrimento envolve deparar-se e confrontar-se com a verdade. Também, a autonomia, na concepção da Bioética Principalista de Beauchamp e Childress (2002), é severamente afetada com esse tipo de postura. Ainda, na ética dialógica de Habermas (2004), não é possível a resolução de um conflito ético na ausência de um diálogo amplo e de partes capacitadas para tal. Ou seja, é o diálogo o que legitima tanto a utilização de tratamentos como a limitação terapêutica. Para Pessini (2001), ações fúteis são antiéticas, mas o simples conceito de futilidade não é autossuficiente. Entretanto, esse autor reconhece que, na complexidade da prática clínica diária, há situações que interferem no que seria a melhor decisão para o paciente: os responsáveis pelo paciente, diante de culpa e responsabilidade, podem tender a pedir todos os tratamentos possíveis existentes, mesmo que isso signifique obstinação terapêutica. Também, as questões financeiras concernentes ao tratamento podem influenciar a decisão: se os custos do tratamento recaem sobre os familiares, é possível que eles tentem minimizar os tratamentos oferecidos. Do ponto de vista do sistema hospitalar, se a remuneração for feita por procedimentos, é possível que haja a tendência ao sobretratamento e, de forma inversa, se os reembolsos por tratamentos forem contingenciados, pode surgir a tendência de não realizar determinados procedimentos (Siqueira 2005). Ou seja, o sistema no qual médicos e pacientes se inserem podem apresentar distorções de ordem econômica, ambos tendo que equilibrar preceitos éticos e jurídicos à realidade econômica que se impõe. Na literatura, há o receio expresso que o conceito de futilidade terapêutica venha a ser usado para justificar a eutanásia, o suicídio assistido, a supressão de tratamentos para neonatos, para idosos e doentes, para poupar parentes, famílias ou o Estado da mera onerosidade financeira, confundindo futilidade de um tratamento com futilidade da vida humana (Pessini 2001, Floriani \& Schramm 2008).

Frente a tais situações, Nunes (2008) conclama que é preciso haver critérios claros de boas práticas clínicas frente a pacientes terminais e que devem ser elaboradas 
diretrizes de orientação ética e clínica que deem suporte aos profissionais para decidir pela limitação terapêutica. Calderón et al. (2010) consideram que, em situações onde não se chegue a um consenso, o profissional assistente deve delegar, ou seja, transferir para outros profissionais ou então para o comitê de ética a decisão final de prosseguir com uma intervenção ou de decidir pela limitação terapêutica. Alonso (2012) levanta que a percepção de médicos, pacientes e familiares acerca de quais cuidados são parte indissociável ao tratamento de pacientes terminais não é totalmente concordante. Ou seja, mais do que protocolos de limitação terapêutica, a assistência ao final da vida deve envolver flexibilidade razoável para o entendimento junto a pacientes e familiares quanto às intervenções que serão realizadas e às que definitivamente não serão utilizadas. Em certos casos, intervenções 'dignas' e 'indignas' não se apresentam com limites precisos, mas como uma continuidade, uma gradação de condições e situações.

Não necessariamente a futilidade terapêutica envolve dano: segundo Fornells (2000), um tratamento pode ser fútil não por ser exatamente danoso, mas por simplesmente não funcionar, ou seja, se for extremamente improvável que se atinja o objetivo clínico. Como exemplo, administrar um antibiótico oral a um paciente terminal de leucemia não é exatamente uma medida danosa, mas pode ser vista como uma medida fútil, uma vez que dificilmente surtirá o efeito desejado. Em uma situação na qual um tratamento seja, além de fútil, danoso, é mais clara a tendência ética de não aplicá-lo ou de interrompê-lo, mas os tratamentos fúteis que não impliquem em dano exigem uma reflexão mais profunda e, sobretudo, considerar os interesses particulares do paciente ao momento que o tratamento esteja sendo proposto.

Nesse ponto, Nunes (2008) ressalta que existem diferenças práticas importantes entre a suspensão e a abstenção de um tratamento, embora do ponto de vista ético essas diferenças sejam menos nítidas. A questão prática é que suspender um tratamento significa que já se conhecem seus efeitos benéficos e colaterais, de modo que o efeito da suspensão (por exemplo, morte em poucos minutos) já é conhecida. Não iniciar um tratamento significa uma decisão frente a um jogo de probabilidades, de uma relação estimada de risco/benefício. Floriani \& Schramm (2008) ressaltam que, embora a autonomia do paciente seja essencial para o planejamento dos cuidados, nem sempre é possível de ser alcançada, uma vez que os pacientes podem não estar em condições clínicas para decidir, de modo que a decisão médica deve ser tomada baseada em 
diretrizes antecipadas ou então em protocolos clínicos consolidados, sobretudo para o caso de responsáveis que insistam em solicitar tratamentos fúteis e altamente danosos ao paciente. Ou seja, a tomada de decisão de limitação terapêutica é um processo bidirecional, no qual a equipe médica deve estar embasada em protocolos, mas os pacientes e responsáveis devem estar cientes de tudo e participarem do processo.

Conforme França et al. (2010), o exemplo mais emblemático da limitação terapêutica é o da ordem de não-reanimação. A reanimação cardiopulmonar consiste, essencialmente, na ventilação do paciente com instrumento de pressão aérea positiva e massagens tóraco-cardíacas, associadas ou não à infusão de drogas e aplicação de eletrochoque para controle de arritmias. Manobras básicas de reanimação são do domínio e conhecimento dos profissionais de saúde em geral e Enoch et al. (2009) preconizam que seja algo a ser ensinado a toda a população. Conforme Pessini (2001), os pacientes internados em hospitais, ainda que sejam terminais, serão encaminhados, após um evento de parada cardíaca, para unidades de terapia intensiva e receberão manobras de reanimação cardiorrespiratória, a menos que ordem expressa em contrário esteja registrada em seu prontuário. Assim, antes de se pensar em qualquer outra limitação terapêutica, é preciso, primeiramente, questionar se um determinado paciente tem indicação de reanimação. A decisão de não-reanimação cardiorrespiratória carrega um profundo simbolismo. Em pacientes terminais, a probabilidade de benefícios é tão pequena que as manobras de reanimação podem ser consideradas fúteis: uma sobrevida inicial de horas ou dias pode se suceder em menos de $50 \%$ dos pacientes, mas nenhum sobrevive para alta hospitalar (Almeida 2010c). A condição clínica prévia do evento de parada cardiorrespiratória é o dado que prevê a maior ou menor chance de sucesso frente às manobras de reanimação. De forma similar, é a condição clínica do paciente ao momento de se iniciarem tratamentos invasivos em geral - como aminas vasoativas, ventilação mecânica e diálise - o maior preditor de sucesso terapêutico (Cremesp 2008).

A decisão de não-reanimação, portanto, não é algo estanque, mas uma indicação de conduta que pode variar conforme ocorram mudanças nos objetivos do tratamento. Como exemplo, se algum período a mais de vida, ainda que curto, pode representar a oportunidade de regularização de questões da esfera pessoal do paciente, então a decisão a ser tomada pode ser a de tentar a reanimação. Essas situações, contudo, não se atêm ao contexto clínico e são abordadas pelo poder judiciário, que pode emitir decisões que 
obriguem o provimento de tratamentos tidos como fúteis ou como obstinação terapêutica (Almeida 2010a).

França et al. (2010) analisaram dilemas éticos dos enfermeiros frente a ordem de não-reanimação de um paciente. Como tópicos éticos, foram abordadas as questões de quem toma a decisão, quem toma conhecimento da decisão, quem concorda ou discorda e quais seriam etapas para reavaliação da decisão. Assim, uma ordem de não-reanimação segue os passos de decisão, registro em prontuário, conhecimento da equipe de saúde, dos pacientes e dos familiares e reavaliação posterior da decisão. Os autores deixam claro que é uma decisão de responsabilidade essencialmente médica, mas, considerando que manobras de reanimação são área de atuação tanto de médicos como de enfermeiros, os autores não citaram algum conflito jurídico envolvendo enfermeiros que realizaram manobras de reanimação à revelia de uma ordem médica. Inclusive os autores levantaram dados que, na percepção dos enfermeiros, os pacientes sob ordem de não-reanimação recebem cuidados que poderiam ser classificados como de obstinação terapêutica, mostrando que o simbolismo dessa decisão médica não é suficiente para que os cuidados se limitem ao que for realmente de interesse do paciente.

Pessini (2001) conclui que, eticamente, deve ser afastado o conceito puro de obstinação terapêutica para o conceito mais amplo de provisão de cuidados apropriados ao paciente. Floriani \& Schramm (2008) mostram que os cuidados paliativos se inscrevem dentro do campo concreto dos cuidados no fim da vida como uma proposta que concilia o princípio da sacralidade da vida com o princípio da qualidade de vida. Os Cuidados Paliativos, portanto, equilibram-se entre os polos antagônicos da eutanásia e da obstinação terapêutica, rejeitando a ambos. Ao fugir da obstinação terapêutica e se confrontar a ela, os Cuidados Paliativos buscam controlar não o processo de morte em si, mas sim com os sintomas, as síndromes que circundam o processo de final de vida. Não se pode saber o momento exato que a morte ocorrerá, mas podem-se usar fármacos contra dor, vômito, dispnéia, delírio, sede, fome, dentre outros sintomas. Em outras palavras, a ética dos Cuidados Paliativos surge para confrontar a figura da obstinação terapêutica, surgida com a medicalização da morte. Os Cuidados Paliativos são um modo de inter-relacionar uma possibilidade de agir, propiciada pela tecnologia, com o dever de agir, este no campo ético, justificado, portanto, em um sistema de valores. 


\section{Princípios dos Cuidados Paliativos}

Segundo a Associação Brasileira de Cuidados Paliativos $(2006,2009)$ e o Cremesp (2008), os Cuidados Paliativos operam sob os seguintes paradigmas:

a) promover o alívio da dor e de outros sintomas desagradáveis;

b) integrar os aspectos psicológicos e religiosos/espirituais aos cuidados ao paciente;

c) afirmar o valor da vida e da dignidade humana, mas vendo a morte como um processo inevitável, o qual não deve ser nem acelerado nem adiado além dos limites possíveis da terapêutica existente;

d) oferecer suporte para que o paciente possa viver ativamente e de forma o mais independente possível;

e) oferecer suporte aos familiares e entes queridos e por fim;

f) ser iniciado o mais precocemente possível.

Os pacientes são reconhecidos como tendo os direitos:

a) À vida e a vivê-la em plenitude e dignidade;

b) À informação sobre a doença, história natural, estágio de evolução, prognóstico, tratamentos, efeitos colaterais e tudo o que for necessário para a tomada de decisão;

c) À autonomia e ao respeito à sua vontade;

d) À assistência integral;

e) Ao alívio do sofrimento; 
f) À intimidade e privacidade;

g) Aos cuidados imediatos após a morte, ou seja, respeito ao corpo e acesso às manifestações de despedida e dor dos familiares e entes queridos;

h) À assistência ao luto dos familiares.

Como forma de se garantir a autonomia e o respeito da vontade do paciente, tem surgido a experiência das Diretrizes Antecipadas de Vontade, documento de teor ético no qual o paciente decreta quem é (são) as pessoas mais legítimas em representar sua vontade, os princípios gerais de tratamento, etc. No Brasil, é uma iniciativa relativamente recente, regulamentada pela Resolução CFM 1995/2012.

Receber Cuidados Paliativos não necessariamente significa limitação terapêutica nem deixar de receber os recursos diagnósticos e terapêuticos que estiverem disponíveis. Significa, sim, que os recursos devem ser usados de forma racional e hierarquizada, levando-se em consideração, primordialmente, os benefícios que podem trazer e evitandose os malefícios. A abordagem dos sintomas deve ser feita de forma antecipada, ou seja, o controle dos sintomas se baseia em:

a) não esperar que o paciente se queixe ou apresente piora significativa;

b) avaliar antes de tratar;

c) explicar e dialogar sobre as causas dos sintomas;

d) monitorar os sintomas, reavaliando regularmente as medidas terapêuticas;

e) atenção aos detalhes e

f) haver pronta disponibilidade de atendimento ou suporte.

A avaliação rotineira dos sintomas dispõe de escalas de pontuações (Cremesp 2008, ANCP 2009, Capelas 2009). Existem, por exemplo, adaptações para a realidade brasileira acerca do quadro de avaliação dos sintomas do serviço canadense da cidade de Edmonton que servem como guia para o tratamento paliativo. Vale ressaltar que 0 tratamento não se baseia unicamente em fármacos, sendo que todo recurso de alívio não- 
farmacológico - psicoterapia, acupuntura, fisioterapia - deve ser oferecido ao paciente, caso o mesmo se sinta confortável e perceba melhoras com essas medidas.

De acordo com a ANCP $(2006,2009)$, os preceitos da Bioética Principalista de Beauchamp e Childress (2002) são aplicáveis na fundamentação ética dos Cuidados Paliativos. Assim, o princípio da beneficência é entendido, sobretudo, como relacionado a dois pontos essenciais: controle de sintomas e qualidade de vida. A não-maleficência é entendida conjuntamente com a limitação terapêutica, no sentido de se evitar a prática da obstinação terapêutica, não se utilizando procedimentos invasivos e agressivos. A preservação da autonomia dos pacientes é considerada de extrema importância no processo decisório, evitando-se os abusos de um julgamento unilateral (Oliveira \& Silva 2010). Dado que a qualidade de vida seja subjetiva e individual, a escuta do paciente com relação a dúvidas e experiências é o que orienta a trabalhar com as necessidades do paciente. $O$ princípio de justiça envolve distinguir quais tratamentos são benéficos ao paciente e quais se caracterizam por obstinação terapêutica. Para essa distinção, existem índices estatísticos que ajudam a definir condutas (Rego \& Palacios 2006), tais como o KPS, a síndrome de anorexia e caquexia, a presença de dispneia e os fatores metabólicos (distúrbios de eletrólitos, linfopenia), etc (ANCP 2009). Ainda assim, essas escalas, embora norteiem condutas e possam defender os médicos de uma eventual acusação de negligência, necessitam de contato contínuo e aberto com os familiares e entes queridos dos pacientes. É importante que a família esteja em sintonia com os princípios dos Cuidados Paliativos, o que requer tempo e justamente um dos fatores que indicam a precocidade de início do suporte (Oliveira et al. 2009). A família é considerada integrada ao serviço quando não insiste em tratamentos caracterizados por obstinação terapêutica, o que decorre quando os familiares se sintam incluídos no processo decisório e tranquilos em compreender a limitação de esforços terapêuticos.

\section{Operacionalização dos cuidados paliativos}

Frente ao diagnóstico de doença crônica progressiva e ameaçadora à vida indica que os Cuidados Paliativos devem ser indicados na vigência de qualquer fase de evolução: 
trata-se da possibilidade de óbito por evolução da doença, a qual pode se arrastar por anos (Pessini \& Bertachini 2006). Para pacientes com câncer, a fase de diagnóstico é a mais complexa e que sempre necessita de suporte emocional para aceitar a doença e suportar os desconfortos inerentes ao tratamento. Para os pacientes com falências funcionais de órgãos e quadros demenciais, o comportamento da doença tende a ser mais lento e repleto de intercorrências agudas, denominadas no âmbito dos Cuidados Paliativos de crises de necessidades. Após cada crise, a capacidade funcional do paciente declina e a recuperação raramente remete ao patamar anterior de funcionalidade, até que se crie uma situação de alta dependência, momento no qual a paliação se torna imperativa e se indica a limitação terapêutica, evitando-se tratamentos invasivos e dolorosos (Figura 1). Nessa fase, não apenas o doente, mas toda a família e seu entorno afetivo devem receber suporte. Comumente, o paciente apresenta dificuldade em expressar sofrimento e sintomas, de modo que os cuidadores terminam por perceber sutilezas que indicam necessidades de suporte e tratamento. 
Figura 1: Modelos qualitativos de fim de vida em relação à vitalidade. Em A, morte súbita. $B$, doença aguda, grave e fatal. C, doença crônica que reduz a expectativa de vida: cada declínio e recuperação corresponde a alguma intercorrência clínica aguda. $\mathrm{D}$, similar a $\mathrm{C}$, mas a vitalidade nunca foi plena.
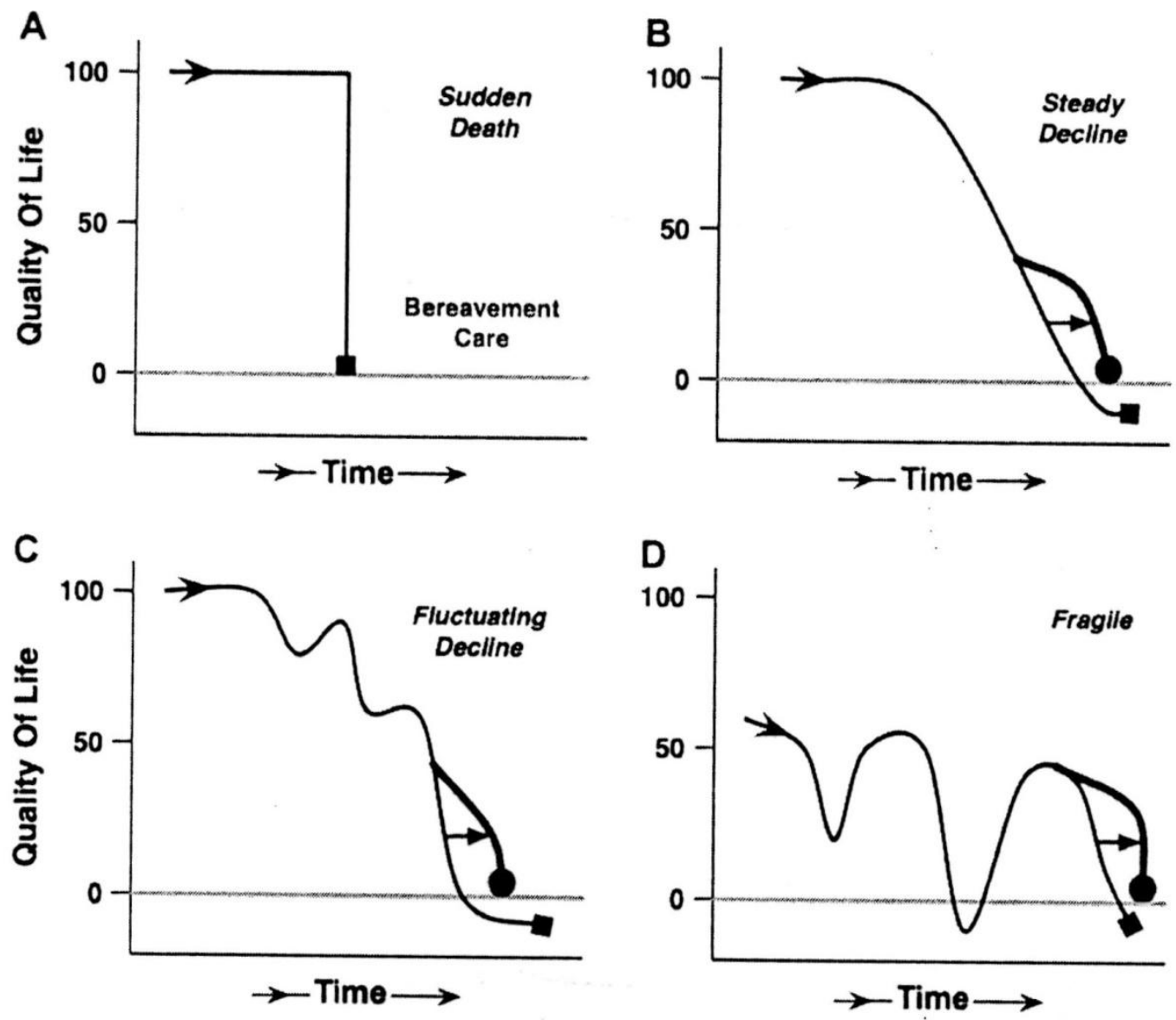

Fonte: Feudtner (2007). 
No âmbito dos Cuidados Paliativos, são elementos essenciais os tratamentos visando ao controle/redução de:

a) controle da dor;

b) dispneia, tosse, hipersecreção de vias aéreas;

c) náusea e vômitos;

d) constipação e diarreia;

e) fadiga, sudorese e prurido;

f) delírio e convulsões;

g) ansiedade e depressão;

h) cuidados com feridas e curativos;

i) cuidados em ostomias;

j) higiene e conforto;

k) realização de procedimentos cirúrgicos de alívio;

I) tratamento de emergências - hemorragia, síndrome de compressão da veia cava, síndrome de compressão medular;

m) fadiga, anorexia, caquexia;

n) providências práticas para toda a família.

$\mathrm{Na}$ fase de dependência, os cuidados no leito para prevenção de escaras, o cuidado e as adaptações com a alimentação e a comunicação honesta e aberta com os cuidadores são o cerne do tratamento. As intercorrências agudas devem ser tratadas de modo mais parcimonioso, evitando-se as intervenções agressivas e que reduzam ainda mais a funcionalidade do paciente. Os procedimentos de conforto - curativos, mobilizações, aspiração de vias aéreas - devem estar sempre presentes. Importante que a parcimônia 
no tratamento seja feita de forma racional e rigorosa, para jamais se confundir com negligência (Marta et al. 2010).

Como orientações técnicas, em 2002 Harlos adaptou a escala de Karnofsky aos Cuidados Paliativos, demonstrando que apenas 10\% dos pacientes com escala PPS (Palliative Performance Scale) igual a 50\% sobrevivem mais de 6 meses (ANCP 2009). Também, a fase final de vida coincide com PPS em torno de $20 \%$. Ou seja, embora o futuro não possa ser previsto, essas escalas permitem uma estimativa cientificamente embasada para a observação de prognóstico. O fato de estar em situação terminal significa que há cuidado a ser prestado, mas o que muda é o enfoque. Os Cuidados Paliativos não se baseiam exatamente em protocolos a serem copiados rigidamente, mas em princípios a serem seguidos (Cremesp 2008). Os princípios de Cuidados Paliativos foram classicamente desenvolvidos e direcionados a pacientes com câncer, mas, aos poucos, as condições de doenças neurológicas vêm criando peculiaridades e reforçando os princípios dos cuidados paliativos: os pacientes portadores de doenças neurológicas degenerativas, demências, acidentes vasculares cerebrais, deficiência mental podem ser abordados sob os princípios da escala PPS e, no caso da doença de Alzheimer há, por exemplo, a escala do Functional Assessment Staging, que orienta os cuidados paliativos (Vilela \& Caramelli 2009). Ainda assim, há muitos pacientes em condições de fragilidade intensa, que apresentam declínio progressivo de vitalidade e para os quais vem surgindo indicações de Cuidados Paliativos, como pneumonias aspirativas recorrentes, insuficiência cardíaca grau IV, hepatopatia com albumina sérica inferior a 2,5 g/dL, nefropatia com creatinina sérica maior que $6 \mathrm{mg} / \mathrm{dL}$, doença pulmonar obstrutiva crônica com dispneia de repouso e sinais de cor pulmonale. A ANCP (2009) traz tabelas mais detalhadas dessas condições crônicas que indicam gravidade e morte iminente. E mesmo dentro do ambiente de Unidades de Terapia Intensiva, há indicações de Cuidados Paliativos nos casos de pacientes de longa permanência ou mesmo recorrência de internações em UTI.

\section{Peculiaridades da Pediatria}


Em pediatria, a morte é considerada como um evento não-natural e não-esperada. Se ao ser humano a morte é um evento indigno, a morte de uma criança gera ainda mais revolta e frustração, sendo particularmente um evento desafiador (Pessini 2001). A criança representa a vida que recomeça e a própria continuidade dos pais e dos avós, de modo que a morte de uma criança é um grande fator de estresse para os pais e familiares, os quais se apresentam com um risco aumentado de luto complicado e desencadeamento de disfunções psíquicas. $\mathrm{O}$ avanço tecnológico, no âmbito pediátrico, criou uma situação peculiar: se a mortalidade de crianças sadias é um evento cada vez mais controlado por políticas públicas de saúde, por outro, um contingente cada vez maior de crianças vivem com condições clínicas crônicas e complexas. Assim, se até a metade do século XX a mortalidade infantil era elevada, atualmente, a sobrevivência das crianças é uma meta global de saúde pública, de modo que a experiência atual de luto frente à perda de uma criança não apresenta o mesmo significado de até há poucas décadas atrás (Capelas 2009).

Cerca de um terço da mortalidade infantil ocorre no período neonatal e metade ocorre no primeiro ano de vida. No período neonatal - primeiros 28 dias de vida pósnascimento - as principais causas de morte são prematuridade, malformações congênitas, asfixia perinatal e sepse. Na faixa etária pediátrica, segundo a ANCP (2009), os Cuidados Paliativos são aplicáveis para crianças em quatro situações: a) doenças para as quais o tratamento potencialmente curativo falhou (neoplasias, cardiopatias congênitas ou adquiridas); b) condições nas quais o tratamento prolonga a sobrevida e muitos pacientes chegam à vida adulta, mas a morte no período pediátrico é previsível, como fibrose cística, infecção pelo HIV, malformações gástricas, epidermólise bolhosa, insuficiência renal; c) condições nas quais o tratamento é exclusivamente paliativo, como erros inatos do metabolismo para os quais não houver tratamento específico, doenças neurodegenerativas, anormalidades cromossômicas e d) condições neurológicas não progressivas, mas que resultam em alta suscetibilidade e frequência de crises agudas (crises de necessidades): prematuridade extrema, paralisia cerebral, malformações cerebrais, encefalopatia hipóxico-isquêmica neonatal.

O Cuidado Paliativo em pediatria dá suporte para as crianças e as suas famílias a viverem e restaurarem a sua totalidade quando se encontram diante dessas condições clínicas complexas que limitam ou ameaçam à vida. Nem toda criança sob Cuidados Paliativos está perto de seu fim, e o ideal é a inclusão precoce no serviço (Capelas 2009). 
Os Cuidados Paliativos em Pediatria se baseiam nos mesmos princípios gerais do tratamento do adulto, ao manter o mesmo valor básico da dignidade humana (Rego \& Palacios 2006), mas alguns pontos devem ser levados em consideração, pois crianças não são adultos em miniatura, não seres humanos em desenvolvimento e em uma fase de grande dependência de um ou mais adultos responsáveis:

- A Pediatria atende a uma ampla faixa etária - do neonato ao adolescente, de modo que cada período da infância apresenta necessidades específicas e o impacto da doença crônica, frente ao desenvolvimento, ora atrasa alguns aspectos fisiológicos, ora acelera certas aquisições. Em comum, crianças criticamente doentes recebem cuidados intensivos, intervenções mais precoces;

- De uma maneira geral, os médicos conhecem pouco sobre as doenças raras que impactam a infância; embora cada uma delas seja rara, em seu conjunto são frequentes o suficiente para que os pediatras se deparem com elas em algum momento. No entanto, esse aspecto dificulta que se desenvolvam protocolos de limitação de esforços terapêuticos;

- O tempo de doença na infância pode ser prolongado, sendo variável e imprevisível, de modo que é difícil prever a resposta à terapia instituída, de modo que quando há decisões que envolvem juízos de valor sobre qualidade de vida da criança, estas geram emoções e conflitos muito intensos e profundos;

- O luto da família e do círculo de relacionamento da criança é frequentemente mais intenso e de maior duração. Por sua vez, a criança cronicamente enferma sofre um luto antecipado, decorrente de isolamento progressivo, perda de funções, perda do convívio escolar. Frente aos irmãos, a criança doente pode fazer com que o foco de atenção da família se torne exclusivo, principalmente durante os períodos de hospitalização, e esse aspecto deve ser adequadamente abordado pela equipe de Cuidados Paliativos.

$\mathrm{Na}$ Pediatria, é reconhecidamente necessário que se desenvolvam estudos e pesquisas de modo a otimizar os princípios de cuidados e sensibilizar a equipe de saúde que atende crianças com esse perfil de doenças. A ANCP (2009) e Capelas (2009) citam escalas específicas de avaliação de funcionalidade: o Escore de Lansky, o Escore ECOG e o Escore Zubrod, os quais podem auxiliar a tomada de decisões. A Academia Americana de 
Pediatria ainda observa barreiras para a faixa etária pediátrica: por exemplo, para o adulto, a literatura estipulou 6 meses de vida como indicativo de limitação terapêutica, mas será o mesmo período válido para a faixa etária pediátrica? Diante de tantos quadros variados em pediatria, cada qual com um número restrito de casos, há como criar princípios gerais de limitação de esforços? De todo modo, independentemente dos questionamentos sobre limitação terapêutica em pediatria, a abordagem para o alívio dos sintomas requer reavaliações frequentes e observar, pela ótica da criança, quais procedimentos e tratamentos são os mais eficazes no controle dos sintomas. Por exemplo, se para um adulto uma punção venosa significa um leve desconforto, para a criança isso pode simbolizar uma dor excruciante a ser evitada, sobretudo na fase terminal de uma doença.

Muitas vezes, conforme a doença progrida, começam a existir as diferenças de opinião entre a equipe médica que assiste a criança e os seus responsáveis sobre a reversibilidade da condição, e sobre novas intervenções de diagnose e/ou terapêutica. Existe uma tendência mais nítida em direção à obstinação terapêutica por parte dos responsáveis, que não raro buscam e aceitam todo tipo de tratamento 'alternativo', na crença que, mesmo doloroso, um tratamento pode significar uma esperança em longo prazo. Mesmo em situações nas quais o benefício das intervenções médicas se mostrem limitados, segundo a ANCP, a carência de diretrizes sobre as opções éticas e legais contribuem para o viés de obstinação terapêutica. Em consequência, crianças cronicamente enfermas, na fase crítica de sua doença terminam por sofrer de dores e desconfortos de modo desnecessário. Idealmente, antes que os momentos finais cheguem, é preciso que a equipe médica e os familiares tenham feito um bom trabalho em conjunto.

Muitas crianças em fase terminal não se desenvolveram ao ponto de compreender sua condição e expressar seus sentimentos. Sempre que possível, o paciente pediátrico deve ser estimulado a participar e ouvir as discussões e decisões. Segundo o Cremesp (2008), o desejo de proteger a criança entra em conflito com a percepção que ela pode morrer. A informação deve ser fornecida de modo claro e de modo compatível com o grau de maturidade da criança. A criança é tutelada pelo Estado, de modo que o grau de domínio do poder dos pais não é absoluto nem inquestionável: muitas vezes a capacidade de tomada de decisão dos responsáveis é relativizada quando as suas escolhas são inconsistentes com as recomendações do corpo clínico, ou, em situações mais extremas, 
houver história de doença mental, droga adição, abandono ou disputa não resolvida entre os genitores, cabendo à equipe de saúde provar que os responsáveis estão sem capacidade para tomar as decisões. Os responsáveis têm autoridade para discordar, colocar limites às intervenções propostas e solicitar procedimentos, mas a grande questão é se esses aspectos se mostram coerentes e encontram respaldo ético. Ou seja, é sempre necessário balancear a autoridade dos pais com a responsabilidade profissional.

\section{Classificação por níveis de risco}

Os pacientes podem ser classificados segundo três níveis de risco. Os níveis de risco são descritos em função das necessidades de tratamento, baseados no grau de sofrimento ou na deterioração da qualidade de vida, que não necessariamente representam iminência de morte (Márquez 2009, Marta et al. 2010). O sistema de classificação deve ser flexível e considerar o sintoma mais grave. Assim, no nível I, são pacientes com diagnóstico de doença crônica potencialmente fatal no médio prazo. Tem por objetivos a promoção do bem-estar e da qualidade de vida do paciente e sua família, detecção das necessidades atuais e localização das unidades de tratamento, controle de sintomas físicos, implementação de intervenções educacionais, terapêuticas, psicológicas e sociais, apoio espiritual e prevenção do luto complicado. O nível II é composto por pacientes com problemas médicos, psicológicos, sociais ou espirituais que não podem ser controlados no nível I. O nível II agrega ao nível I: resolução de urgências e emergências, criação de espaços de comunicação entre a família, o paciente e a equipe relacionados aos últimos dias ou horas, prevenção de síndrome de desgaste profissional, promoção de cuidados domiciliares e de condições adequadas de modo a possibilitar o óbito no domicílio, conforme o desejo do paciente, de acordo, por exemplo, com as diretrizes antecipadas de vida. O nível III são pacientes na etapa paliativa com problemas de maior risco que não podem ser resolvidos no nível II e agregam: atenção ao paciente, à família e ao entorno com sofrimento máximo, implementação de programas assistenciais de máxima complexidade, promoção de internações para recuperação familiar, disponibilidade de interconsulta de outros níveis e especialidades. 


\section{As últimas 48 horas de vida}

As últimas horas de vida se caracterizam por rápido declínio funcional. A importância de reconhecer esse momento é evitar investigações clínicas invasivas, procedimentos desnecessários, bem como tratamentos fúteis. O foco do tratamento é o de controle e alívio dos sintomas. Os sinais das últimas horas de vida são: anorexia intensa, imobilidade, sonolência, delírio, choque circulatório, piora da dispneia. $O$ suporte às últimas horas pode ocorrer tanto em ambiente hospitalar ou então no próprio domicílio, decisão que depende da estrutura familiar e de como foi construído o suporte de Cuidados Paliativos (Sales 2000).

A anorexia deve ser reconhecida como fisiológica e o efeito de hidratação e nutrição por sonda deve ser avaliado, pois tanto a sonda em si pode ser desconfortável, como surgirem náuseas, vômitos, aspiração brônquica, desconforto abdominal. Nesse momento, a hidratação deve ser cautelosa para evitar congestão sistêmica e a hipodermóclise, ou seja, infusão lenta, subcutânea, de até $1500 \mathrm{~mL} /$ dia de fluidos isotônicos pode ser indicada. Nem sempre a sensação de secura é desidratação, pode ser apenas secura labial, aliviada com gaze umedecida (ANCP 2009).

A imobilidade, embora comum nas últimas horas, pode provocar úlceras de pressão, de modo que regularmente o paciente deve ser mobilizado, mas sem insistências desnecessárias, pois o paciente pode referir que a mobilização seja muito dolorosa. A sonolência deve ser observada e respeitada, inclusive com a noção que pode haver alucinações e problemas de memória. Contudo, a agitação psicomotora pode estar refletindo desidratação ou intoxicação por opiáceos, de modo que a hidratação deve ser reavaliada e o uso do opiáceo pode ser reduzido em 20 a 30\%. Se preciso, pode ser feito o uso de neurolépticos (ANCP 2009).

A dor, nas últimas horas, pode se exacerbar, podendo mesmo se tornar refratária ao tratamento. Raramente surge uma dor nova nessa fase, que já não estivesse presente antes dos momentos finais (Sales 2000). Nesse momento, a suspensão abrupta de sedativos e opióides pode trazer abstinência física e somar desconforto ao paciente. A 
dispneia pode estar associada a causas reversíveis, como derrame pleural, ascite. O uso de morfina, de benzodiazepínicos, de oxigênio por cateter pode aliviar esse sintoma. Diante do choque circulatório, a punção venosa torna-se ainda mais difícil e mais dolorosa para o paciente. Nesse momento, a hipodermóclise consiste na colocação de scalp ou cateter na região subcutânea abdominal, onde hidratação e a maioria dos fármacos usados em Cuidados Paliativos podem ser administrados (ANCP 2009).

Nas últimas horas, há uma agonia final. Além das medidas de conforto clínico, o suporte espiritual e familiar são fundamentais nessa fase. A terapêutica deve seguir uma lógica racional com foco no alívio dos sintomas. A maioria dos medicamentos para doenças crônicas, como hipertensão e diabetes, podem e devem ser suspensas, assim como profilaxia de trombose, diuréticos, antidepressivos, antiácidos. Em ambiente domiciliar, é importante que os responsáveis tenham à mão e saibam administrar morfina, haloperidol e diazepam. O trabalho da equipe de Cuidados Paliativos deve estar sincronizado e detalhado, respeitando-se as singularidades de cada paciente e familiares. A assistência ao luto é um dos elementos mais importantes na equipe de Cuidados Paliativos (Taboada 2000, Calderón et al. 2010).

\section{Limitação terapêutica}

No âmbito dos Cuidados Paliativos, uma discussão importante diz respeito à limitação de esforços terapêuticos (Nunes 2008). Uma primeira decisão, que suporta as demais limitações, é pela ordem de não-reanimação cardiopulmonar. A aceitação dessa limitação é fortemente simbólica e deve ser uma decisão tomada em conjunto da equipe com o paciente e familiares. Significa que o paciente e os familiares reconhecem a terminalidade da situação clínica, que uma eventual sobrevida a manobras de reanimação será breve e que não há soluções para o controle da doença. A opção de não-reanimação jamais pode ser confundida com eutanásia, omissão de socorro ou suicídio assistido, mas sim uma opção consciente frente a uma realidade que se impõe. Da mesma forma, uma ordem de não-reanimação não pode ser imposta ao paciente para admissão a serviços de saúde, e na ocorrência de fatos novos na vida do paciente, é uma decisão que pode ser revertida (França et al. 2010, Alonso 2012) . 
Em seguida à ordem de não-reanimação, uma segunda etapa diz respeito à ventilação mecânica. A ventilação mecânica é um procedimento avançado de suporte vital que envolve a colocação de um tubo traqueal e exige, depois, sedação, controle da dor, restrição ao leito; em certos casos, é preciso mesmo que o paciente receba curare para que o suporte ventilatório seja eficaz. No contexto real, há duas ações a serem tomadas: uma, a de não intubar o paciente, não iniciar ventilação mecânica. A outra é uma ação de extubação, na qual se desconecta o paciente do respirador. O problema ético é que, ao se desconectar um respirador, a morte é usualmente imediata, o que confunde o procedimento com eutanásia (Nunes 2009). A dispneia é um dos sintomas mais prevalentes do paciente terminal, de modo que optar por não intubar significa reconhecer que, a partir daquele momento, o paciente terá o sofrimento aumentado em decorrência da ventilação mecânica e a sobrevida, se houver, será pequena e caracterizada por dor total. Assim, a dispneia será tratada mediante outras técnicas menos invasivas, como oxigênio nasal sob cateter, cpap nasal, medicações relaxantes e de alívio, etc.

Os tópicos ainda mais controversos em Cuidados Paliativos dizem respeito à hidratação e à nutrição artificiais: constituem um tratamento básico de suporte a todos os pacientes? Para quais pacientes não há benefícios? Para quais tipos de pacientes a nutrição e hidratação artificiais podem aumentar o desconforto e o sofrimento? A nutrição, quando não é possível por via oral, é oferecida por meio de sonda nasoentérica, menos invasiva, mas que 'deforma' a fisionomia do paciente, gastrostomia ou por via parenteral. Nutrição e hidratação são percebidas como aspectos básicos da existência humana e cuja ausência - fome e sede - pode ser considerada como um dos piores sofrimentos que uma pessoa pode experimentar. Assim, a princípio, a nutrição e a hidratação ajudam a reduzir o sofrimento e somente em casos muito específicos e estritos podem ser consideradas como tratamentos invasivos e fúteis (Benarroz et al. 2009).

Pacientes terminais necessitam de quantidades menores de água para se sentirem satisfeitos. Conforme a doença e o estágio de evolução, a própria sensação de fome e sede é reduzida, o que se manifesta pela inapetência. Para esses pacientes, uma alimentação normocalórica pode se constituir em fator de sofrimento, com sintomas de náuseas, vômitos e empachamento. O Cremesp (2008) menciona que para os casos neurológicos em geral - estado vegetativo persistente, doenças neurodegenerativas, acidente vascular encefálico, trauma craniano - a alimentação por sonda nasoentérica ou 
por gastrostomia é um suporte terapêutico essencial à sobrevida. Para pacientes oncológicos, o suporte nutricional invasivo melhora o estado geral e nutricional do paciente. Para pacientes terminais de demência e para pacientes oncológicos em estado terminal, o decréscimo da função renal pode fazer com que a nutrição artificial, se não for bem dosada e adequadamente reduzida, provoque aumento das secreções respiratórias, dispneia e até mesmo edema pulmonar e ascite, ou seja, sintomas de hiperidratação e hipervolemia sistêmica. Ainda, do ponto de vista ético, e com base na fenomenologia, o paciente demencial terminal, ao momento em que perde a habilidade de ingestão de alimentos, provavelmente não experimenta desconforto nem sofrimento com o jejum, de modo que a nutrição artificial - por meio de sonda ou gastrostomia - não melhore o prognóstico geral do paciente, embora aumente a sobrevida. Assim, ainda não há princípios gerais que garantam que a decisão de suspender ou de não introduzir suporte nutricional e hidratação seja uma medida real de alívio de sofrimento; há, sim, o reconhecimento que nos últimos dias de pacientes oncológicos terminais, a alimentação forçada pode provocar ainda mais desconforto (ANCP 2009).

\section{Aspectos jurídicos da limitação terapêutica}

Apesar de a obstinação terapêutica ser considerada um desvio ético, a atual legislação não positivou essa figura (Almeida \& Schramm 1999). Existe legislação contrária à negligência, à imprudência, à eutanásia, mas não existe, formalmente, uma lei contrária aos excessos, à hipermedicalização de um paciente terminal. Dessa forma, a limitação ética de esforços terapêuticos pode ser confundida com negligência ou com eutanásia passiva, a morte por pura omissão (Simone 2000).

Dessa forma, não costuma haver, do ponto de vista legal, denúncias contra médicos que atendam às demandas de pacientes por tratamentos fúteis. Segundo Pessini (2001), o principal óbice à futilidade terapêutica provém não do aparato legal, mas da remuneração pelo serviço prestado: no contexto de clínicas privadas, em um momento de crescentes custos na saúde e, sobretudo, na concentração de gastos em saúde ao final da vida, começaram a surgir glosas e redução de remuneração para procedimentos diversos. Essa situação mostra que o debate sobre futilidade terapêutica tem implicações éticas muito 
sérias que vão além da decisão clínica. Segundo Pessini (2001), é fundamental que se defina quem é qualificado para avaliar se os tratamentos são desejáveis ou apropriados. Provavelmente, uma empresa de seguros em saúde interessada na economia de custos não é o melhor ente indicado.

Do ponto de vista ético, é a dignidade humana o valor máximo a ser defendido, e nesse aspecto existe total concordância com o aparato legal. No Brasil, o Conselho Federal de Medicina editou a Resolução n. 1.805/2006, afirmando em seu Art. $1^{\circ}$ que: " $E$ permitido ao médico limitar ou suspender procedimentos e tratamentos que prolonguem a vida do doente em fase terminal, de enfermidade grave e incurável, respeitada a vontade da pessoa ou de seu representante legal." O Ministério Público Federal recorreu judicialmente da decisão, afirmando, entre outros argumentos, no Processo n. 2007.34.00.014809-3 que " o direito à vida é indisponível, de modo que só pode ser restringido por lei em sentido estrito”. O despacho final da sentença foi favorável ao CFM, como visto no trecho: "o médico limitar ou suspender procedimentos e tratamentos que prolonguem a vida do doente na fase terminal de enfermidades graves e incuráveis, realmente não ofende o ordenamento jurídico posto".

Em continuidade, o CFM editou a Resolução n. 1995/2012, sobre as Diretivas Antecipadas de Vida, instrumento que respaldaria, eticamente, o médico em uma eventual decisão de limitação terapêutica, desta vez sob vontade expressa e prévia do paciente ou seu representante legal. Novamente, o Ministério Público Federal entrou com ação civil pública para suspender a Resolução, mas a Justiça Federal em Goiânia indeferiu o pedido.

Ou seja, o pensamento jurídico de promotores, no momento atual, no máximo autoriza o médico a, em um contexto de cuidados paliativos, restringir procedimentos diagnósticos e terapêuticos. Ainda não houve, no âmbito jurídico, processo contra a obstinação terapêutica, pelo contrário, atos de obstinação terapêutica podem estar equivocadamente sendo tratados como 'manutenção do direito à vida de um paciente', conforme argumentação do Ministério Público.

Esse vácuo jurídico, dessa condição bioética emergente, deixam os médicos inseguros quanto a sanções legais. Embora uma boa comunicação geralmente previna esse tipo de ocorrência, conforme o Cremesp (2008), é preciso lembrar que há, são poucas, mas há, pessoas mal-intencionadas que podem tentar se aproveitar desse vácuo 
jurídico para obter vantagens. Ainda, na área penal, a linha de pensamento dos promotores apresenta um viés que tende para a obstinação terapêutica.

Por sua vez, o paciente tem o direito de recusar tratamentos. Não há lei federal que explicite esse princípio, mas em São Paulo a Lei n. 10.241/1999 afirma o direito do paciente recusar tratamentos dolorosos ou extraordinários. Também, com base no Estatuto da Criança e do Adolescente, a Resolução do Conselho Nacional dos Direitos da Criança e do Adolescente n. 41/1995 afirma que é direito ter uma morte digna, junto aos familiares, quando os recursos terapêuticos estiverem esgotados.

Almeida (2010c) elenca as atitudes já registradas frente a conflitos entre médicos e pacientes, sob o ponto de vista legal, no que tange à limitação terapêutica:

a) Seguir a decisão familiar e continuar com os investimentos diagnósticos e terapêuticos;

b) Recorrer ao sistema judiciário para obtenção de liminar que garanta a suspensão ou limitação do esforço terapêutico;

c) Ignorar a decisão familiar e suspender ou limitar esforços sem comunicação detalhada;

d) Ignorar a decisão familiar, suspender ou limitar esforços, mas com comunicação detalhada;

e) Insistir em conversar com a família para convencê-los sobre a necessidade de limitação de esforços terapêuticos;

f) Recorrer ao comitê de ética do hospital para intermediar as negociações e tomada de decisão;

g) Dar alta da UTI para continuidade de tratamento em enfermarias ou unidades de menor complexidade.

De todo modo, o documento do Cremesp (2008) lista os quesitos para que a ação médica, no intuito de beneficiência ao paciente terminal, não seja mal interpretada:

a) comunicação franca e aberta com pacientes e familiares; 
b) documentação verdadeira em prontuário das atitudes, processos decisórios e condutas tomadas. A documentação irreal dos fatos pode facilmente ser verificada mediante depoimento das testemunhas que presenciaram o fato.

Além desses aspectos, a ANCP (2006) chama atenção para a necessidade de os Cuidados Paliativos serem iniciados o quanto antes para que haja a percepção que 0 paciente jamais foi desassistido, mas sim que com a evolução da doença, os objetivos do tratamento evoluem. Do ponto de vista técnico, há princípios e diretrizes que podem se aplicar às doenças mais prevalentes, como neoplasias em estágio avançado ou demências.

Em conclusão, na atual conjuntura legal, não é a equipe médica assistente que irá, subitamente, tomar uma decisão de limitação terapêutica, mas sim uma atitude construída ao longo de um tratamento crônico. O respaldo dos comitês de ética hospitalar é de grande valia para que as decisões tomem um caráter institucional, o que atua também como modo de defesa profissional neste momento de transição legal (Calderón et al. 2010).

\section{3 - Neuroética}

Segundo Júnior (2010), o termo 'neuroética' refere-se a um campo da Bioética que aborda os problemas éticos relacionados às funções e disfunções cerebrais e também ao exame moral em questões biomédicas/tecnológicas que abordam o cérebro, como aperfeiçoamento, manipulação, interface com máquinas, psicofarmacologia, etc. Do ponto de vista orgânico, o cérebro é a sede da nossa humanidade, personalidade, bem como do julgamento ético e moral, sendo um órgão insubstituível, personalíssimo e integrador maior de todo o organismo (Filho \& Junges 2015). Em uma primeira definição, clássica e simplista, a consciência desenvolvida do adulto livre, autônomo e responsável é considerada como essencial para o exercício da razão prática, sendo um pré-requisito para qualificar os seres humanos como entes morais. A consciência de um cérebro sadio, portanto, fundamenta a dignidade, a autonomia e a liberdade.

Nas sociedades pós-modernas, a liberdade e a saúde - esta sendo entendida em um sentido mais amplo e que engloba a atenção sanitária, saúde pública, seguridade 
social - são valores tão próximos que chegam à quase-igualdade (Kottow 2001). Os princípios reconhecidos como sendo do direito à vida, geralmente cristalizado nas Constituições, abrangem questões do direito à saúde, de modo a ser um correlato do próprio direito à vida. $\mathrm{O}$ atendimento à saúde é concretizado pelos profissionais da área, de modo que é composta por interfaces entre a técnica, a política e a ética, não sendo nem um puro saber, menos ainda um puro fazer, mas um campo integrador de saberes no qual a dimensão ética ocupa um lugar central (Almeida 2010a).

Segundo Castro \& Zúñiga (2002), a neuroética tem apresentado dois extremos de fundamentação: um, que crê no livre-arbítrio e na presença de uma alma superior que permite fazer escolhas e determinar as ações. O outro, determinista, recusa o conceito de livre-arbítrio, acreditando que vivemos em um mundo predeterminado e que estabelece padrões recorrentes de decisão e comportamento, o que tornaria previsíveis as decisões e ações tomadas pelos indivíduos. Similar dualidade é apontada por Lauterslager (2010), que aponta dois pólos de conflito no que tange aos valores humanos: o primeiro, uma visão de respeito a toda vida humana individual e o outro, remetido ao lluminismo, fundamentado no respeito e na autonomia do indivíduo. Quando o ponto de vista de uma dessas tradições é apresentada como verdade única, sem atender a particularidades, circunstâncias excepcionais, a resposta a perguntas surgirá rapidamente, de maneira superficial, simplista, reducionista e unidirecionais que suprimem a amplitude do conflito moral, reduzindo-se a antagonismos embasados apenas na vontade particular de cada grupo. No entanto, os conflitos bioéticos apontam que não há apenas dois valores fundamentais, mas uma pluralidade deles. Nenhuma perspectiva humana é definitiva; as circunstâncias devem ser analisadas no contexto real no momento de determinar a responsabilidade ética, com a necessidade de analisar a situação frente às circunstâncias médicas, psicológicas, sociais (Diniz \& Ribeiro 2003).

Dessa maneira, a neuroética encontra-se envolvida na discussão sobre o conceitochave de pessoa, que traz consigo o valor intrínseco da dignidade humana: os indivíduos com disfunções ou lesões cerebrais evocam reflexões de ordem da redefinição e do reconhecimento do que seria a pessoa humana (Kottow 2001, Pessini 2005). Como exemplos, o demente, os mentalmente incapazes, os pacientes em estado vegetativo persistente, etc. são reconhecidos como seres humanos de pleno direito e plena dignidade? São passíveis de serem imputados penalidades em decorrência de seus atos? 
Deixariam de ser reconhecidos como seres humanos? Formam uma categoria intermediária de valores? São considerados tais quais as crianças?

Pode ocorrer um impasse ético e conceitual decorrente da aplicação extremada do paradigma de associar humanidade à razão, estabelecendo uma em função da outra. Por um lado, a consciência pode ser relacionada a uma base biológica de capacidade de intelecção e cognição, mas, por outro, o reconhecimento mútuo de humanidade que os indivíduos se atribuem decorrem de um processo inter-relacional. Como bem classifica Almeida (2010c), há três posições para a definição do que seja humano: a concepcional, a evolutiva e a relacional. A concepcional indica que o momento de formação do zigoto origina a pessoa humana; a evolutiva valoriza a potencialidade existente no indivíduo em se tornar adulto e consciente; e a relacional, que considera o atributo do humano como sendo um processo social. Assim, sob a perspectiva que tornar-se humano é um fato social, torna-se possível fundamentar a ampliação das situações em que se reconhece humanidade (e, por conseguinte, dignidade), a um indivíduo, ainda que por motivos diversos sejam ou estejam impossibilitados de exercer sua autonomia. Essencialmente, a dignidade é um conceito que visa à inclusão, e não à exclusão social.

Ainda que se respeite a prerrogativa de serem todas as pessoas iguais em direitos, nem todas possuem a capacidade de autodeterminação na mesma medida (Castro \& Zúñiga 2002). No âmbito jurídico, isso se traduz nos conceitos de incapazes, parcialmente capazes e plenamente capazes no que tange às responsabilidades e direitos civis (Almeida 2010c). Quem, inclusive por questões de desordens cerebrais, carece de determinados atributos, continua seguindo como ser humano, mas apresenta uma humanidade de modo incompleto, com possibilidades reduzidas de realização de um projeto de vida pleno. Mas, ainda que não sejam capazes civilmente, podem inspirar uma moral benevolente, ou seja, todo ser humano é um sujeito moral em plenitude, possuindo direitos iguais. Mas somente os indivíduos que façam por merecer o atributo de pessoa plenamente capaz é que adquire a capacidade de atuar moralmente, ou seja, reconhecidamente capaz de atuar de forma racional e moral. A partir desse ponto, a pessoa é um sujeito moral que assume também um aspecto de agente (Júnior 2010).

Tão importante quanto a definição da categoria do humano é a definição de quando efetivamente começa uma vida humana, ou, mais precisamente, quando a vida humana se 
torna individualizada, afinal, se a vida é um valor desde seu início, gera-se o dever de protegê-la (Kottow 2001). O começo da vida é mais um conceito ético do que biológico, porque desse conceito dependerão os julgamentos morais frente a esse início. Dessa forma, deve-se evitar incorrer na falácia naturalista, ou seja, a de se restringir a dados biológicos para atribuir valores éticos. Como todo conceito a respeito da ética, qualquer perspectiva é parcial e incompleta se não contemplar a prioridade dos valores expressos pelos diretamente afetados por essa decisão. Ou seja, o desenvolvimento de habilidades sociais de expressar os pensamentos, estabelecer relações interpessoais e alcançar inserção social são mais definidoras daquilo que de fato é uma pessoa do que meramente o resultado biológico de uma gestação (Lauterslager 2000).

Castro \& Zúñiga (2002) descrevem o conceito de desmoralização não como sinônimo de vergonha, que é a acepção popular da palavra, mas como falta ou diminuição da moral, no sentido de ausência de participação na ordem social. A pessoa desmoralizada é aquela que não apresenta ou então que perdeu a capacidade de satisfazer suas necessidades sociais e exercer papéis comunitários. Essa incapacidade inter-relacional, em situações extremas, pode culminar na perda do reconhecimento social de sua dignidade, tornando-se, assim, um ser asilado dentro da própria sociedade. Com relação às incapacidades cognitivas de natureza congênita, os autores mostram que, na História, houve períodos em que tais crianças eram consideradas monstruosidades, produtos de castigo divino ou então de maldições, mas que também há sociedades que consideram esses casos como sendo o contrário, ou seja, as crianças malformadas que apesar de tudo sobrevivem foram consideradas como exemplos de um poder divinal em criar exceções à regra. Em todo caso, na grande maioria das vezes, a exclusão social tem sido a forma mais habitual nas diversas culturas, que as consideram como indignas de compartilhar com o resto da comunidade, sendo maltratadas, exiladas ou mesmo assassinadas (Gort et al. 2010).

\section{Anencefalia}


A anencefalia é uma malformação embrionária do tubo neural na qual se verifica ausência completa ou parcial da calota craniana e grau variado de malformação e destruição dos esboços do cérebro exposto (Cremeb 2004). Verifica-se, portanto, ausência dos hemisférios cerebrais e dos tecidos cranianos que os encerram com presença do tronco encefálico e de porções variáveis do diencéfalo. A ausência dos hemisférios e do cerebelo é variável. $O$ feto anencefálico é intrinsecamente inviável para a vida extrauterina: de 75 a $90 \%$ dos anencéfalos são natimortos; dos que nascem com vida (ou seja, que respiram), cerca de $60 \%$ morrem em 24 horas, mas 15\% sobrevivem três dias, sendo excepcionais os casos que alcançam uma semana sem medidas avançadas de suporte. Ainda assim, a literatura registra casos atípicos, esporádicos, em que a sobrevivência extrauterina superou um ano de idade (Gomes 2003, Oliveira 2005).

A existência de fetos anencéfalos suscita debates de ordem ética a respeito do status social que thes concerne, o que reflete nas condutas médicas passíveis de serem aceitas eticamente (Gomes 2003). No período pré-natal, existem discussões entre médicos e gestantes a respeito do que fazer ante um diagnóstico de acrania: se acompanhamento regular da gestação ou se interrupção voluntária da gestação (Cremeb 2004). Uma vez nascido o feto, existem debates sobre a pertinência da adoção de medidas extremadas de suporte à vida e também sobre a questão da doação de órgãos antes que a parada cardíaca se estabeleça (Diniz \& Ribeiro 2003).

Com relação ao período pré-natal, o embate bioético oscila entre a posição concepcional, a posição evolutiva e a posição relacional na definição de humano. Assim, sob a alegação do pressuposto de vida e da atribuição do status de pessoa aos fetos, a posição concepcional argumenta contrariamente à permissão à interrupção voluntária da gestação nos casos de anencefalia, pois, enquanto dentro do útero o feto é um indivíduo vivo, ainda que com curta expectativa de vida, e que merece a proteção do Estado. De fato, o anencéfalo não necessariamente é natimorto: ao nascimento, pode haver manifestação de choro, de modo que ele recebe um atestado de nascimento e outro de óbito (Almeida 2010c).

Entretanto, dentro da posição evolutiva, no caso do anencéfalo não existe uma vida futura que possa ser afetada, uma vez que há a ausência de um substrato essencial para o desenvolvimento pessoal. A posição evolutiva já traz o paradigma que o conceito de 
pessoa é embasado em um fato biológico, mas que não se restringe a esse fato, transcendendo ao meramente concreto. Trata-se de crianças incapazes de desenvolverem toda forma de racionalidade, consciência e pensamento e que terão uma expectativa de vida muito curta, mas ainda assim reconhecidas como seres revestidos de dignidade e que terão direito ao atendimento à vida e, portanto, ao atendimento à saúde (Almeida 2010c). Do ponto de vista ético, uma vez reconhecido o anencéfalo como ausência de desenvolvimento futuro, a tendência, no Brasil, é que o Poder Judiciário reconheça situações semelhantes e autorize, por exemplo, a interrupção voluntária da gestação diante do diagnóstico pré-natal de outras doenças igualmente graves, como outras malformações cerebrais, erros do metabolismo ou malformações graves em geral (Gazzola \& Melo 2015).

Pela posição relacional, não apenas o anencéfalo, mas todo feto nascido vivo tornase humano somente com a presença da figura de uma pessoa nutriz, que geralmente é a mãe biológica, mas que pode ser concretizada por intermédio de qualquer adulto capaz de proteger e satisfazer as necessidades do neonato e conduzi-lo à vida adulta e independente (Lauterslager 2000). Assim, é possível que uma gestação seja tanto aceita como recusada pela mulher que se vê grávida. Ao momento que a mulher se veja como mãe, assume-se a primeira relação inicial que dará o status de pessoa ao embrião que se desenvolve. O status de pessoa do embrião em desenvolvimento, portanto, depende de duas condições: da consciência da mulher em estar gestante e da aceitação dessa condição (Oliveira 2005).

O debate bioético sobre a conduta médica pré-natal com relação a fetos anencéfalos apresenta interfaces jurídicas nos Estados onde o aborto, mesmo que voluntário e a pedido da mãe, somente não é considerado crime em casos estritos, como é o Brasil. As leis que criminalizam o aborto, no caso do Brasil, datam de um período anterior ao surgimento da tecnologia de diagnóstico pré-natal, de modo que há um vácuo legal. Nesse contexto, a anencefalia constitui-se em uma situação excepcional, na qual a proteção ao feto se acompanha de uma sobrecarga à mulher gestante, inclusive com riscos para a saúde da mãe, havendo um conflito entre princípios gerais que se mostram insuficientes para guiar decisões morais. Nesse sentido, o aborto do anencéfalo tende à preservação da saúde materna. É o intenso sofrimento parental, além dos riscos inerentes a toda gestação, o embasamento prático para a aceitação ética do aborto do anencéfalo 
mesmo dentro da ótica concepcional (Diniz \& Ribeiro 2003). Kottow (2001)considera que na ausência de substratos biológicos essenciais, existe naturalmente uma diferenciação moral, ou seja, a ótica evolutiva traz que a definição de pessoa não é um binário, mas sim uma gradação, gerando diferenciações morais. Ainda assim, Sá (2014) questiona se, diante de uma gestação de anencéfalo, existe de fato autonomia da mãe em decidir a respeito de sua gestação ou se há pressões para que ela decida pelo aborto.

Lucena et al (2009) questionou sobre a pertinência da doação de órgãos por fetos anencéfalos. Segundo o autor, haveria iniciativas para que as gestantes de fetos anencéfalos fossem encorajadas a manter a gestação até o final, e, uma vez tendo o feto nascido, teria seus órgãos removidos e doados. Essa iniciativa seria embasada no conceito de morte encefálica como fim da vida: embora o ordenamento médico-legal tenha adotado a morte encefálica como indicador do final da vida, isso não quer dizer que todos os outros órgãos e tecidos estejam mortos. Para a constatação de morte encefálica, é preciso haver dados clínicos que mostrem ausência de atividade cerebral, incluindo o tronco cerebral, além de exames complementares que mostrem ausência de circulação sanguínea intracraniana, atividade elétrica cerebral ou atividade metabólica cerebral. Inclusive, Meneses et al. (2010) haviam denunciado as condições de trabalho em centrais de captação de órgãos no Brasil, que muitas vezes, por falta de recursos para os exames necessários, ou perdiam doadores ou implicavam em remoção de órgãos sem todos os quesitos completos, expondo a vulnerabilidade dos profissionais em condições inadequadas de trabalho.

Assim, uma vez que o feto anencéfalo ou então portador de malformações cerebrais tiverem manifestado funcionamento de tronco encefálico (respiração e choro), não podem ser considerados clinicamente mortos. Ou seja, se o feto anencéfalo se apresentar como natimorto, é pouco provável que seus órgãos sejam aproveitáveis; se manifestar choro, receberá um atestado de nascido vivo e outro de óbito, mesmo que este venha pouco tempo depois. Assim, Lucena et al. (2009) conclui que, à luz do conhecimento médico atual, não é ético autorizar a retirada de órgãos de um feto anencéfalo que respira, uma vez que este é considerado um humano vivente e, portanto, portador de dignidade.

\section{Morte cerebral e estado comatoso irreversível}


Desde milênios até a década de 1960, a morte de um indivíduo era considerada concomitante e após a parada cardiorrespiratória. Contudo, a partir do surgimento da tecnologia biomédica de suporte clínico cardiorrespiratório, o conceito de morte foi modificado tendo em vista a ocorrência da possibilidade de dissociação entre a atividade metabólica vital do coração e atividade vital do cérebro. A vítima de uma parada cardíaca passou a ter a possibilidade de reanimação, recuperando suas funções vitais, com com seqüelas de gravidades distintas (Meneses et al. 2010).

Segundo Oliveira (2005), vivemos em um ambiente de pluralidade no qual as pessoas não compartilham as mesmas definições sobre a vida e a morte. Assim, começam a surgir dificuldades em definir, precisamente, o momento no qual a vida termina. Com o advento dos transplantes de órgãos e tecidos, inaugurou-se nova abordagem ao que vinha sendo considerado o fim da vida. A viabilidade dos transplantes rompeu uma barreira conceitual e introduziu a noção de morte cerebral como critério de fim de vida de uma pessoa. A lesão cerebral grave e irreversibilidade de funções exigiu nova compreensão sobre o término da vida. A ocorrência da morte deixou de ser fenômeno súbito e terminal, tornando-se processo evolutivo, dinâmico, complexo, e, sobretudo, sequência de eventos terminativos. Kottow (2001) resume que o processo de morrer e a morte devem ser submetidos a novas revisões conceituais que considerem que a tecnologia disponível criou realidades historicamente alheias às manipulações tecnocientíficas. Nesse quesito, Oliveira (2005) considera que a extensão, a gravidade da doença e, sobretudo, o prognóstico, são elementos essenciais para a definição dos limites das intervenções biomédicas.

Nos pacientes portadores de lesões cerebrais em decorrência de traumas, neoplasias, acidentes vasculares, hipóxia-isquemia secundária ao processo de reanimação cardíaca, etc., é possível que eles entrem em estado de coma permanente. O estado de coma permanente, ou estado vegetativo, é um contexto clínico de não-reação, ausência da consciência de $\mathrm{si}$, falta de respostas comportamentais, aos estímulos ambientais, mas com conservação das funções autônomas e outras funções cerebrais. $O$ estado vegetativo não se confunde com a morte encefálica. A morte encefálica é considerada um evento específico da região do tronco encefálico e, por conseguinte, das regiões encefálicas 
situadas superiormente. Mas é possível haver morte de grande parte do encéfalo, mas que, ao manter vivas determinadas áreas controladoras das funções vitais mais básicas, é possível a vida por um período mais prolongado do indivíduo, sobretudo com o uso de tecnologia de suporte aos sistemas vitais: ventiladores mecânicos como suporte respiratório, marca-passos e medicações como suporte cardíaco e mesmo a terapia dialítica, em substituição ao sistema renal (Pessini 2005). Os sistemas substitutivos de órgãos, quando usados prolongadamente, geram efeitos colaterais deletérios, de modo que boa parte das intercorrências são relacionadas aos problemas do uso crônico. Portanto, em geral, o doente em estado vegetativo não pode ser considerado doente terminal, e embora esteja sujeito a inúmeras intercorrências clínicas de gravidade maior ou menor, muitos se adaptam bem a tais condições e se prolongam vivos de modo estável e indefinido por muitos anos. Assim, emergiram os conflitos éticos relacionados à indicação, aplicabilidade e manutenção dos suportes avançados de vida. Essas questões se referem à relação entre tentativa e resultado, ou seja, os problemas concernentes à adoção de uma determinada tecnologia e os resultados, ou seja, se sucesso terapêutico total, parcial, se ocorrência recorrente de danos e efeitos colaterais, etc (Castro \& Zúñiga 2002).

Pessini (2005) enfatiza que o paciente em estado vegetativo tem direito a uma correta e aprofundada avaliação diagnóstica, visando evitar possíveis erros e orientar intervenções de reabilitação; a uma assistência de base, que inclua hidratação, nutrição, aquecimento e higiene; à prevenção das possíveis complicações e controle de qualquer eventual sinal de restabelecimento; a um processo adequado de reabilitação, que favoreça a recuperação e manutenção dos objetivos alcançados; e a ser tratado como qualquer outro doente grave em termos de cuidado. Ou seja, o fato de um indivíduo encontrar-se em uma situação complexa e historicamente nova e recente não o faz perder o valor essencial dos Direitos Humanos, qual seja o da dignidade.

Porém, Pessini (2005) nos lembra que o conceito de dignidade é polissêmico e carrega diferentes significados de valores éticos, chegando mesmo a ser usado na defesa de valores antagônicos. No caso, segundo Gomes (2003), dois valores básicos podem entrar em contradição nessas situações-limite desses pacientes: o da sacralidade da vida e o da qualidade de vida. A raiz desse conflito se estrutura ao redor de um conceito que é, por si, ambíguo: o da morte com dignidade. Essa ambigüidade advém do fato que a morte é o evento inexorável que mais indigna os seres humanos. 
Assim, por um lado, há uma visão materialista que valoriza e radicaliza a liberdade e a autonomia pessoal, elegendo o doente como protagonista maior de seu processo de morte, admitindo como ponto de partida moral que não é toda vida que merece ser vivida, tal como a situação de doença e sofrimento sem perspectivas de alívio, com dependência permanente dos outros, deterioração corporal progressiva, etc. Por outro lado, há uma visão metafísica, advinda dos ditames morais das religiões, que considera que justamente porque a vida é um atributo indefinível e indecifrável, não cabe ao homem decidir pelo momento de sua morte, mas aguardar que essa advenha 'naturalmente' (Kottow 2001).

Segundo Almeida (2010a), esse conflito, quando concernente aos pacientes em estado vegetativo, evidencia que, na prática, a dignidade humana seria intrinsecamente vinculada à autonomia, de modo que, na perda de possibilidade de interação social, a autonomia reduzida pode redundar em uma dignidade também reduzida. Pessini (2005) considera que a dignidade é o valor que reveste tudo o que não tem preço, não tem medida. Não há mais e menos dignidade, não há equivalente nem substituto para seu valor. A noção de dignidade humana repousa sobre seu ser; é um reconhecimento de valor, um princípio moral baseado na finalidade do ser humano e não na sua utilização como meio, sendo considerada um atributo inalienável. Assim, a dignidade continua sendo vista e presente onde muitos vêem somente sofrimentos sem sentido e deficiências em todos os graus (Almeida 2010b). Se o conceito de dignidade se reduzisse a estar presente apenas nos períodos de plena capacidade, então os seres humanos igualmente se veriam reduzidos ao seu desempenho, de modo que a dignidade poderia ser ganha ou perdida, contrariando, assim, os fundamentos dos Direitos Humanos (Diniz \& Ribeiro 2003).

A autonomia, por sua vez, pode ser incluída nas discussões sobre dependência e independência. Quanto maior for o grau de independência, maior a probabilidade de autonomia. Mesmo em condições de dependência parcial, o sujeito ainda pode ter sua autonomia preservada, a depender dos arranjos sociais que for capaz de estabelecer. $\mathrm{Na}$ verdade, a questão da dependência/autonomia não é necessariamente uma contradição, podendo ser uma oposição não excludente. No caso do cuidado à saúde, todo trabalho implica algum grau de tutela, pois todo serviço assistencial tem caráter protetor. Quanto menos o sujeito depende dos serviços assistenciais, maior é o grau de autonomia que ele apresenta no que tange a esse aspecto de sua vida (Almeida 2010b). 
Rotineiramente, existem pacientes cuja competência e capacidade cognitiva estão prejudicadas. Estender a aplicação do princípio da autonomia a pessoas mentalmente incapacitadas configura distorção. É assim que no contexto clínico, a assistência à saúde, ao ter um caráter de tutela, não pode admitir autonomia absoluta dos procuradores/responsáveis pelos pacientes incapazes, uma vez que há uma ética, uma responsabilidade profissional frente aos cuidados básicos que um paciente tem direito, dentro de sua dignidade (Almeida 2010c).

Assim, diante de um paciente em estado vegetativo persistente, existem cuidados básicos que não podem ser retirados. A autonomia não é um conceito que permite decisões atentatórias à vida; o doente em estado vegetativo é pessoa humana e merece respeito a seus direitos fundamentais. Uma decisão de suspensão de cuidados básicos, como nutrição, hidratação, higiene tem a conseqüência conhecida e previsível da morte, configurando-se mesmo como um ato de tortura (Pessini 2005). Mas isso não quer dizer que toda a tecnologia disponível deva ser usada, nem por tempo indefinido. Justamente, a ética dos Cuidados Paliativos aponta que, principalmente as tecnologias de ponta, há um sofrimento intrínseco a tais procedimentos, cujo resultado, em um contexto de terminalidade de vida, pode mais trazer sofrimento do que aliviá-lo (Oliveira 2005).

De todo modo, o conhecimento adquirido permite que se tenha uma visão humanística das pessoas portadoras de incapacidades mentais: o reconhecimento da importância da pessoa, das suas limitações e capacidades e da transcendência do entorno social como fator condicionante da integração. É assim que foi declarada a importância da modificação do ambiente construído, eliminando ou reduzindo barreiras físicas e comportamentais, bem como a garantia de apoio pessoal e individualizado.

4 - Autonomia, dignidade e responsabilidade profissional

A terminalidade da vida envolve uma complexidade de eventos que desafiam os profissionais da saúde à medida que acrescentam outros elementos no contexto da relação médico-paciente como a ética do cuidado, a humanização e o respeito diante o sofrimento do outro (Ribeiro 2011). A compreensão dos princípios (bio)éticos e 
deontológicos envolvidos, que neste sentido não se restringem apenas na compreensão de saúde e intervenção da doença, mas requer uma maior análise das variáveis presentes ao lidar com a morte digna iminente (Nunes 2008) e suas implicações regulamentares e legais da responsabilidade médica e de outros profissionais da saúde envolvidos na proposta terapêutica, considerando-se a autonomia do médico e do paciente e das circunstâncias que interferem em suas expectativas quanto ao atendimento (Tavares 2008).

Rodrigues (2012) aponta que a questão ética da medicina paliativa implica em questões existenciais em que a alteridade da morte se confronta com seus fundamentos éticos básicos: a responsabilidade intransferível, a deferência respeitosa e o paradoxo da vulnerabilidade como expressão da dignidade humana. A responsabilidade intransferível ou sem escapatória não está relacionada diretamente a uma boa consciência, é um imperativo que pode remeter à impossibilidade de liberdade do sujeito, por determinismo investida no próprio bem antes que o sujeito pudesse ter liberdade à escolha. Neste caso, a consciência e a alteridade são a resposta à vulnerabilidade do outro, representando um domínio da medicina sobre o tempo e o domínio da vontade sobre a vulnerabilidade humana, uma tomada de consciência do não domínio, que requer uma relação compassiva com o outro, uma relação ética com o outro.

Monte (2009) defende a necessidade de se conhecer historicamente a importância da dimensão social à ética médica como elemento fundamental na compreensão do relacionamento médico-paciente dada a sua influência no comportamento estabelecido, normatizado, fiscalizado e limitado por leis, juramentos e códigos de conduta profissional, ainda não é muito compreendidos por muitos profissionais da saúde na atualidade quanto ao seu aspecto dinâmico e dialético. Para Marreiro (2013) os aspectos júridicos representam um peso significativo na relação médico-paciente, para além dos aspectos éticos, visto que há uma limitação legal que pode resultar em um significativo aumento da responsabilidade dos profissionais da saúde, de resultar em sanções e até mesmo infrações legais.

Os cuidados médicos da vida humana vulnerada nos limites da vida implicam em dilemas morais na relação médico-paciente que podem influenciar nas escolhas e decisões finais do tanto do profissional da saúde quanto do paciente em termos éticos e 
protocolares. Tratar-se da saúde/doença, vida/morte, autonomia/heteronomia, público/privado, social/individual, não se restringe apenas aos cuidados e atenção atribuída ao paciente. Também não representam necessariamente uma abreviação da vida da pessoa, embora permaneça à medida da necessidade do paciente, suspendendo apenas os casos mais fúteis (Pessini 2011). Trata-se de uma ação que requer antes a consideração ética da complexidade da qualidade e condições de vida do paciente terminal e das implicações jurídicas, sociológicas ou científicas que se sobrepõem ao dever profissional e ético na dimensão do agir ao assumir o paradigma existencial, que é a preocupação primordial da bioética.

Cabrera (2004) descreve que as questões éticas relacionadas ao final da vida envolvem a determinação do sujeito em seu trajeto de vida vivida, no sentido e valor da vida a despeito de seus propósitos e fins, de desvalorização ao se deparar com sua própria finitude, do viver para a dor, mantida por coisas e determinada por terceiros, dentro de uma condição específica e alheia aos parâmetros morais que os circunscreve. Considera-se neste contexto o caráter polissêmico dos princípios éticos presentes na terminalidade da vida, na difícil tentativa de delinear o ser, considerando-se primeiro a necessidade de ponderar a questão das diferenças dos sentidos para a vida, na vida, nos intramundos, bem como o sentido do próprio mundo, entre o sentido de vidas e o sentido da vida; pelo valor da vida, a diferença ser/ente, mundano/intramundo é crucial. Neste ponto, o valor sensível da vida humana, referente a agrado, felicidade e valor moral da vida humana, à dignidade, deve ser movimento num plano de impacto, de afeção, num plano existencial vivido que comove a vida humana de uma maneira que a questão do sentido ligado à pura inteligibilidade, não comove. E no plano cotidiano, a perda do sentido da vida, pode se dar em situações de angustia ligadas com o valor sensível ou moral da vida, ou mesmo no valor do ser mesmo da vida, se é o não valioso, em termos sensíveis e morais, ter surgido no mundo, ter um ser, ou uma vida, com independência dos conteúdos concretos que essa vida possa conter.

O valor moral humano, segundo Cabrera (2004) se encontra no intramundo; na justificação lógica de uma vida humana da perspectiva ôntica, a concepção de pessoa delineada pela capacidade de autorrealização, que tem que empenhar-se para seu próprio ser, para procurar, inevitavelmente, fazer a si mesmo. Um ser encurralado pela insaciabilidade de sua vontade, pela mortalidade de seu ser, pelo sofrimento e em todos 
os seus variados desdobramentos, tende a ser com pouco espaço para exercer sua moralidade, no sentido da consideração pelos outros, tem que lidar com a dor da própria existência. A condição psíquica de sofrimento e angústia do paciente terminal muda sua percepção do mundo exterior na visão minimalista, ressignifica a pulsão do prazer no princípio da evitação do desprazer, no consciente negado ao reprimido na ordem prazer/desprazer constitui-se em uma pressão quase insuportável. $O$ inconsciente, denominado contraconsciente, vincula-se ao movimento conflitivo entre algum conteúdo penoso e algum mecanismo de negação, caracterizado como conflito inconsciente em que a realidade ou mundo exterior pode incluir figuras do penoso, e desta forma, representa uma referência desprazerosa que contribui para desencadear o processo repressivo entre diferentes desdobramentos entre prazer/desprazer no qual o princípio do prazer deve enfrentar na decisão consciente e racional associados à mortalidade findante do ser em vários desdobramentos, apontando a presença de uma autonomia confusa quando o sofrimento se intensifica e as decisões são afetadas pela ilusão e opacidade. Assim, a caracterização mais marcante da pessoa humana é a capacidade de própria organização e autodeterminação, emancipação e independência, em outras palavras, sua autonomia.

\section{Autonomia}

\section{Conceito}

Autonomia, palavra de origem grega, é a junção dos conceitos auto - eu, próprio e nomos - lei, regra, domínio, governo. Significa governo próprio, autodeterminação, autogestão. Envolve a conotação de liberdade, de escolha individual, livre de coação (Araújo et al. 2008). Parte da concepção do ser como pessoa humana, com base na moralidade, única realidade que merecem respeito e tem dignidade, porque é um fim em si mesmo, e na autonomia, por ser autolegislador, autofinalizador e merecedor de respeito por não poder ser trocado por algo equivalente (Pessini 2001), ou seja, portador de dignidade, do latim dignitas, a quem se deve reverência, significa que todos os seus direitos devem ser respeitados. Assim, a caracterização mais marcante da pessoa humana 
é a capacidade de própria organização e autodeterminação, emancipação e independência, em outras palavras, sua autonomia.

A autonomia é um termo controverso e complexo com diferentes contextos ao longo da história, tendo como referencial o ser humano no sentido da vida. O sentido da vida, em seu intercurso de 'vida' vivida, segundo Schramm (2009), pressupõe dois paradigmas morais, o da sacralidade de vida, referente aos atos humanos orientados pelo valor moral, e o da qualidade de vida, referente aos atos humanos construídos pelo processo de secularização e revolução científica e biomédica, adaptado à cultura dos direitos humanos e em particular à liberdade e ao exercício da autonomia nas tomadas de decisão referentes à vida pessoal, seu decurso e fim. Um termo que contrapõe ao princípio da qualidade de vida, que legitima qualquer intervenção na vida humana que implique redução do sofrimento evitável, e em maior e melhor bem-estar para os sujeitos da intervenção,um embate filosófico em relação ao conceito 'vida' à medida em que reduz o bíos, característico dos seres autônomos, com biografia e responsáveis pela sua práxis , à condição de zoé, seres "zoológicos", submetidos às leis naturais, ou à condição de impotência na relação poder-potência exercida pelo Estado, na pessoa do médico. Para Garrafa \& Albuquerque (2001), as condições da medicina entram em conflituosidade com as condições humanas marcadas pelas precárias condições físicas e pobreza, a autonomia (da boa morte) perde seu sentido, dado que o sistema de saúde é fortemente influenciado pelo mercado o qual determina as formas de nascimento, vida e morte

Segre et al. (1998) ao resgatar o contexto histórico, semântico e filosófico do princípio da autonomia, caracteriza-o como extremo que o sujeito assume da modernidade. A autonomia está em concordância com as leis éticas universais, desta forma há uma relevância inseparável da liberdade de pensamento da hegemonia da razão frente aos dogmas religiosos e ao peso da tradição a qual o sujeito vai progressivamente incorporando o papel de fundamento do conhecimento, da ação e da razão humana a partir de qualquer julgamento sobre a realidade (Segre et al. 1988). É oportuno frisar que embora haja um referencial da existência de uma Lei Natural em que o homem ao mesmo tempo é contemplado em toda a extensão de sua individualidade e respeito à sua dignidade, não há alcance de atingi-lo na atualidade em termos de direito, ainda que o referencial seja mantido para fins argumentativos. 


\section{Autonomia e a responsabilidade profissional}

Na relação médico paciente, a autonomia aparece como um dos princípios éticos, ou obrigações morais prima facie de respeito à pessoa, que norteiam as ações das práticas biomédicas, entre a regra absoluta e a mera recomendação. Ela deve ser compreendida como governo pessoal do 'eu', livre da interferência controladora de terceiros e, portanto respeitada quanto a decisão, perspectivas e desejos pessoais.

Almeida \& Machado (2010) defendem que a autonomia se distancia de seu arcabouço teórico e filosófico, passando a significar livre consentimento. E neste caso, a atitude médica deve contemplar a pessoa do paciente, inserindo as questões éticas que colocam a dignidade do próprio doente, promovendo condições que propiciem o consentimento informado como a expressão do direito de autodeterminação do indivíduo, ou de sua autonomia, deixando lugar para o direito ao não ser, conforme 0 artigo $6^{0}$ da Declaração Universal de Bioética e Direitos Humanos. A rejeição da importância do princípio da autonomia tem termos absolutos poderá parecer uma negação à cultura dos direitos humanos. Com isso o respeito pelo princípio da autonomia permite compartilhar com o médico a responsabilidade nas decisões clínicas, superando-se a visão paternalista na relação médico-doente, a deliberação mantém o princípio da dignidade.

Para Araújo et al. (2008), a autonomia do paciente confere a ideia de autodeterminação necessária à tomada de decisões que afetam a vida, saúde, integridade físico-psíquica e relações sociais, portanto o bem-estar, à liberdade de pensamento e o respeito à dignidade humana. Na relação médico-paciente, há que se considerar a integridade, como fator da complexidade dos valores individuais as quais não configuram apenas um princípio bioético fundamental, mas uma ação moral e protetora do ser humano. Dificilmente pode se considerar que há uma completa autonomia individual, ainda 
mais quando existe apenas uma forma ou caminho a escolher para a resolução, consideradas a pluralidade de valores e as circunstancias, bem como o aspecto moral essencial que norteia o paciente nas suas relações com o médico.

Pacientes em estado de vulnerabilidade em geral têm o seu poder de decisão reduzido e podem sofrer interferências ou coações do meio externo. Tal fator pode interferir na autonomia do paciente e passa a adquirir diferentes sentidos em função do cenário, ou até mesmo falhar dependendo do estado de saúde do paciente em condições restritivas de saúde.

É esperado que uma pessoa com autonomia reduzida venha a ser controlada por outros e incapaz de decidir,ou agir com base nos seus desejos e planos, e as pressões externas, expressas como forma de desequilíbrio do meio circundante, possam coagir na decisão final do paciente. Segundo Segre et al. (1998), isso representa uma situação de heteronomia, por contemplar outros elementos na decisão do paciente além do próprio paciente. Há o risco de interferência na ação do profissional da saúde em sua relação e comunicação direta como o paciente. Estes fatores podem afetar as relações de respeito entre médico e paciente, podendo resultar em interpretações erradas, ora confundindo beneficência com paternalismo as quais podem reduzir a vontade do paciente a uma disautonomia, ou seja, à falta de autonomia de grupos sociais com a total ausência de liberdade e independência em suas tomadas de decisão.

Heteronomia é a sujeição do indivíduo à vontade de terceiros, ou à vontade de uma coletividade, não pertencentes à razão é às leis morais. Também se refere à vontade ou dominação que molda a ação de alguns profissionais da saúde expressa na forma paternalista de impor a vontade, ignorando a pessoa moral e sua dignidade, bem como a sua história de vida (Guimarães \& Novaes 2005). Kottow (2001) afirma que pessoas em diferentes contextos de vulnerabilidade são potencialmente heterônomos. Quando a vontade autônoma, desapegada da casuística e apegada às leis autorais, todos os fatores que podem influenciar e diminuir a capacidade de autonomia constituem-se em situação na qual prevalece a heteronomia. Não se pode descartar a possibilidade de influência de coerções na necessidade de robustecimento moral e metafísicos a partir dos contornos jurídicos. 
Os cuidados médicos da vida humana nos limites da vida implicam vários dilemas morais que antecedem as escolhas e decisões finais do tanto do profissional da saúde quanto do paciente. Assim os cuidados de final de vida se envolvem na indefinição e imprecisão de conceitos e significados relativos à vida/morte, saúde/doença, autonomia/heteronomia, público/privado, social/individual (Pessini 2001). Trata-se de uma ação que requer antes a consideração ética da complexidade da qualidade e condições de vida do paciente terminal e das implicações jurídicas, sociológicas ou científicas que se sobrepõem ao dever profissional e ético na dimensão do agir.

As questões éticas relacionadas ao final da vida exigem uma prévia contextualização das ações e princípios morais envolvidos na determinação do sujeito, em seu trajeto de vida vivida, no sentido e valor da vida a despeito de seus propósitos e fins. Por fim, a obstinação terapêutica representa o viver para a dor, um fio de vida mantida por coisas e determinada por terceiros, dentro de uma condição específica e alheia aos parâmetros morais que os circunscreve.

Todos os princípios envolvidos na terminalidade da vida são polissêmicos, daí sua dificuldade de definição. E nessa polissemia, a determinação em um único ponto, o fim, se indefine, desafiando a moral de todos os elementos presentes nos últimos instantes de vida; é necessário, pois, ponderar a questão das diferenças dos sentidos para a vida bem como o sentido do próprio mundo (Cabrera 2004).

A condição psíquica de sofrimento e angústia do paciente terminal muda sua percepção do mundo exterior. Cabrera (2009) descreve esta vertente do psiquismo freudiano na concepção minimalista da filosofia analítica, ressignificando a pulsão do prazer no princípio da evitação do desprazer. Na versão minimalista, o consciente constitui-se em uma pressão quase insuportável. $O$ inconsciente, denominado contraconsciente, vincula-se ao movimento conflitivo entre algum conteúdo penoso e algum mecanismo de negação, caracterizado como conflito inconsciente. A realidade ou mundo exterior pode incluir figuras do penoso, e desta forma, representa uma referência desprazerosa que contribui para desencadear o processo repressivo entre diferentes desdobramentos entre prazer/desprazer que o princípio do prazer deve enfrentar na decisão consciente e racional associados à mortalidade findante do ser em vários 
desdobramentos, apontando a presença de uma 'autonomia confusa' quando o sofrimento se intensifica e as decisões são afetadas pela ilusão e opacidade (Cabrera 2009)

\section{Dignidade}

\section{Conceito}

Dignidade vem do latim dignitas, que significa 'a quem se deve respeito' (Pessini 2004). Como exigência ética, em termos de dignidade o ser humano é digno de respeito porque é pessoa. Esse princípio não pode ser tratado de forma simplista, pois que possui um histórico onde foi construído. Também, é um conceito amplo, aplicável e evocado em uma série de situações sociais, de modo que é preciso circunscrevê-lo para a adequação e compreensão dentro do âmbito da Bioética Clínica e, mais precisamente, no âmbito dos Cuidados Paliativos.

No contexto ético historicamente levantado por Junges (2006), a dignidade baseia-se no fato de o ser humano ser pessoa no âmbito de suas estruturas concretas, e sua abertura ao espírito, manifestada na sua natureza racional, portanto único e insubstituível, um a priori ético, com chegada humana na maioridade de sua consciência autônoma, da qual a dignidade encontra sua base. De origem polissêmica, pode representar ora sinônimo de boa vontade, pessoa, respeito, autolegislação. A autolegislação é o elo de ligação entre a moralidade e a dignidade, que facilitou o surgimento da consciência de que o ser humano é digno de respeito absoluto a formulação jurídica dessa dignidade na Declaração Universal dos Direitos Humanos.

$\mathrm{Na}$ prerrogativa do direito há limitações quanto ao valor humano, visto que a formulação jurídica dos direitos dependeu das circunstâncias históricas e culturas que 
encarnaram as implicações éticas do respeito absoluto à pessoa humana. Porém há o risco de indefinição do conceito nas novas concepções da humanidade, como por exemplo, no avanço genômico, onde os instrumentos jurídicos e éticos não alcançam, exigindo novas análises sobre o que vem a ser uma explicação mais realista do indivíduo (Andorno 2009).

Barchifontaine \& Zoboli (2007) defendem que na atualidade quando a dignidade se manifesta o sujeito persegue sua identidade, irradiando como núcleo do ordenamento legal, mesmo na ausência de uma densidade filosófica ao qual defina dignidade enquanto moralidade de um homem médio as quais necessitam dialogar no mesmo campo para manter a aplicabilidade do princípio, havendo também que se considerar as particularidades, as dimensões e todas as circunstancias existentes nos problemas concretos.

De todo modo, no campo da bioética, segundo Pyrrho et al. (2009), a dignidade se estabelece no reconhecimento do outro igualmente digno, e não necessariamente igualmente autônomo.

Dignidade nos cuidados de fim de vida

A sacralidade segue os preceitos da vida nua, em que a condição de direitos fundamentais tornam-se ausentes ou reduzidos. Um termo que se contrapõe ao princípio da qualidade de vida, que legitima qualquer intervenção na vida humana que implique redução do sofrimento evitável, e em maior e melhor bem-estar para os sujeitos da intervenção. Um embate filosófico em relação ao conceito sobre a vida à medida que reduz o bíos, característico dos seres autônomos, com biografia e responsáveis pela sua práxis, à condição de zoé, seres submetidos às leis naturais, ou à condição de impotência na relação poder-potência exercida pelo Estado, na pessoa do médico (Schramm 2009). Em culturas paternalistas típicas em que as condições da medicina entram em conflituosidade com as condições humanas marcadas pelas precárias condições físicas e pobreza, a autonomia da boa morte perde seu sentido, dado que o sistema de saúde é fortemente 
influenciado pelo mercado o qual determina as formas de nascimento, vida e morte (Garrafa \& Prado 2002).

O histórico da boa morte ou "morte feliz" provavelmente originou-se na obra $A$ vida dos dozes Césares por Suetônio no século II d.C. na descrição da morte suave do imperador Augusto, consumada prontamente sem sofrimento (Junges 2006). Um termo acatado na medicina moderna, embasada na cultura narcisista do bem-estar em que a vida é consumir e ter prazer, que busca minimizar o insuportável sofrimento, o qual, no contexto de terminalidade de vida, seria apenas possível com a aniquilação desta, ou seja, a morte. Em todo caso, há interferência no processo de morrer ao mesmo tempo em que a morte é mercantilizada e fetichizada em funerais. O sacrifício da integridade física própria ou alheia só se justifica fundado num consentimento e numa intencionalidade de solidariedade e beneficência (Junges 2006). Amenizar a extenuante condição de sofrimento e dor em situações irreversíveis não configura necessariamente um estado de quebra de equilíbrio ou desregulação. Em geral é moralmente aceito, por reduzir os danos ao paciente, e desta forma possibilitar um fim de vida com respeito e dignidade.

Barroso \& Martel (2012) pesquisaram situações de terminalidade da vida à luz da dignidade da pessoa humana em seus fenômenos éticos e legais e suas variações fáticas às quais influenciam diretamente na conduta dos profissionais da saúde. Os autores observam que dentro de todas as formas de tratamento, voltados à cura e atenuação do sofrimento do paciente, o paradigma legal de obstinação terapêutica não só representa uma agressão ao paciente, e também põe em xeque a liberdade de consciência do profissional da saúde.

A dignidade, ou a importância e inviolabilidade do homem, assegura seus direito à vida. Em situações fronteiriças, a dignidade de fronteira, é requerida considerando-se que todos os seres humanos tem uma dignidade intrínseca. Sendo que o direito à vida é uma pré-condição, ou instrumento que permite a própria dignidade, sua negação leva à inexistência do sujeito da dignidade. Ou seja, em situação de terminalidade de vida, termina havendo uma tensão dentro do próprio conceito, pois a condição de vulnerabilidade requer proteção, ou respeito à dignidade ao qual protege a liberdade e à inviolabilidade do indivíduo, mas a morte culmina na perda do sujeito da dignidade. 
Por sua vez, a responsabilidade médica é formal ou canônica e claramente deontológica mediante os direitos e deveres; é a expressão de um direito, cujos fins estão relacionados com os valores implicados nas definições de saúde e doença, a fim de evitar opções irracionais e impossíveis. No campo deontológico a obrigação moral consiste na otimização das consequências, situadas entre a racionalidade dilemática com base nos pensamentos e princípios absolutos e sem exceções, e a racionalidade problemática, a qual defende que os problemas e as tomadas de decisão precisam ser enfrentadas mediante um processo de deliberação, mais apropriado às decisões prudentes.

Em todo caso, o processo de deliberação exige abarcar os problemas morais, contribuindo-se desta forma para uma construção de uma bioética fundamentada na ética da responsabilidade, sobretudo pela situação concreta, portanto, pelas circunstâncias e conseqüências, sendo fundamentais os contextos narrativos e hermenêuticos. A sentença 'favorecer e não prejudicar' se inscreve em um contexto muito preciso em que evitar incondicionalmente dano direto ao paciente, o primum non nocere, está presente, além de conceder sempre um lugar á avaliação da realidade concreta sobre o que houver decidir, principalmente em situações de doenças crônicas , quando diagnosticada a terminalidade da vida em que é necessário iniciar uma nova estratégia de manejo do paciente, já não orientada para a cura do processo, mas para a paliação dos sintomas e a promoção do maior conforto possível. Nesse caso, o estudo dos dilemas éticos busca se munir de elementos suficientes para a realização de juízos ponderados e prudentes, na tentativa de analisar as diferentes modalidades e dessa forma compreender a sua lógica interna ou suas razões, considerando-se os valores em jogo que levam o paciente a considerar suas condições de saúde piores que a própria morte.

\section{Responsabilidade médica}

Responsabilidade, palavra de raiz latina "responsibilitas, particípio passado de "respondere", responder, estar em condições de responder pelos atos praticados, justificar as rações da próprias ações (Villas-Bôas 2005). Capacidade de assumir responsabilidade e de a elas se obrigar, liberdade e portanto a possibilidade de escolher entre o bem e 0 
mal, assumir a prometer em troca, assumir de forma consciente a autoria do seu agir em todas as suas consquências.

Nas primeiras décadas do Século $X X$, a responsabilidade médica era comumente associada ao uso de medidas paliativas em pessoas a indigentes internados, destituídos de recursos para pagar o próprio tratamento e que, também não usufruíam de alternativas terapêuticas, salvo a utilização de medidas paliativas caracterizadas pela permanência no leito e pelo afeto de cunho paternalista proporcionado pelos abnegados profissionais que deles cuidavam (Junges 2006).

A responsabilidade médica é de suma importância na análise bioética e tomada de decisões por evidenciar elementos que inferem o poder e a assimetria na judicialização da relação médico-paciente. O médico é o profissional responsável que responde juridicamente em caso de erros em casos de hipossuficiência do paciente no domínio de seu corpo (Fabbro 1999). Existem acidentes imprevisíveis, males incontroláveis, provenientes de situações de curso inexorável, independentemente dos esforços dos médicos e equipes e que estão relacionados às limitações da ciência. Entre as liberdades individuais e os interesses coletivos nos cuidados da saúde, há a compreensão sistêmica do que vem a ser a responsabilidade. Em tal contexto, a responsabilidade em bioética para pacientes no estado terminal da vida é acrescida por causa da decisão entre viver e morrer e pela exposição do profissional de saúde que se vê vulnerado pela responsabilidade de um estado de saúde sem perspectiva de cura, consistindo em uma idéia normativa que sustenta considerações essenciais à organização dos coletivos humanos, sendo inevitável sua associação ao 'risco', á 'responsabilidade' e à 'culpa', especialmente no que se refere ao descumprimento das obrigações (Junges et al. 2010).

A complexidade de eventos envolvidos na terminalidade da vida representa uma desafio para os profissionais da saúde, até mesmo por não se propor necessariamente a um estado de saúde do paciente (Kipper 1999). Trata-se de um paradoxo, que em todos os sentidos desarticula a compreensão dos princípios bioéticos, em um espaço fronteiriço que articula diferentes discursos, como o ético e moral, bioético e deontológico, o discurso regulamentar, jurídico e administrativo. Conforme o caso há a necessidade de desenvolver um discurso analítico dos processos, assinalando e mapeando quando necessário caso a 
caso para direcionar uma maior governabilidade e responsabilidade no cuidar (Gracia 2010).

5 - A Heteronomia do paciente pediátrico

Etimologicamente, heteronomia vem do grego - hetero, outro; nomos - governo, ou seja, o outro governa a mim. Na relação social entre adultos, a heteronomia pode adquirir um duplo significado: tanto o de proteção, no caso do adulto fragilizado ou temporariamente incapacitado, como também o de exploração, escravidão, conforme a acepção de Almeida \& Machado (2010). Contudo, diante da dependência total da criança, na faixa etária pediátrica a heteronomia adquire o significado primordial de proteção, ainda que a infância seja um período particularmente suscetível a explorações sociais de toda ordem.

Piore (2004) registra o comportamento parental brasileiro desde o século XVIII dos pais para com os filhos e mesmo com as crianças em geral: carinhos sem limites até por volta da idade dos sete anos, quando, então, ocorria uma dura transição para as obrigações da vida adulta e para a apartação do convívio por classe social. Quando esse preceito é transferido para o ambiente de cuidados médicos, surgem questões a respeito de seus responsáveis: quem são, qual o grau de autonomia, qual a margem de liberdade para tomada de decisões, quais os limites éticos frente à recusa, pedido ou aceitação aos procedimentos médicos (Leone 2009). O mais importante, conforme Gaiva (2009), é que as crianças são cidadãos de direitos e a infância ganhou papel de relevância na sociedade. Figueira (2010) classifica o respeito ao exercício da autonomia em três posturas: libertarismo, protecionismo e paternalismo. No libertarismo, a criança exerce os mesmos direitos que os adultos assim que apresentar capacidade para tal. No protecionismo, a criança necessita de proteção e da intervenção dos profissionais para prevenir ou evitar situações de risco. E no paternalismo, as crianças são representadas em sua totalidade pelo genitor psicológico, o qual as protege até a maioridade. Leone (2009) considera que esse tópico envolve certo grau de anomia ética, ou seja, ausência de regras preestabelecidas e rígidas, o que torna possível que as normas existentes sejam questionadas. 
Nas palavras de Leone (2009), se nas relações humanas houvesse apenas o respeito mútuo, principalmente nas relações entre adultos e crianças e entre crianças e seus cuidadores, não haveria necessidade de leis e normas jurídicas específicas a protegerem e tutelarem os interesses dos menores. Embora a regra seja que os cuidadores desejem o bem máximo das crianças, a exceção não é rara; ao contrário, ocorre com uma freqüência grande o bastante para que haja motivação para o surgimento de medidas estatais especificamente direcionadas à proteção e tutela da infância e juventude.

As crianças, sendo dependentes e incapazes, encontram-se à mercê de seus cuidadores, que nem sempre são completamente capacitados a decidir, por livre arbítrio, em função dos melhores interesses da criança. Por exemplo, é muito possível que os pais não façam idéia do fardo que os espera, quando se trata de uma criança severamente doente, a qual necessitará de cuidados prolongados por alguns anos antes de seu fim. Especialmente na América Latina (Salinas 2011), mas inclusive em Portugal (Gomes 2010), a desigualdade social é muito marcante, e nos estratos sociais de menor escolaridade, predomina uma postura paternalista por parte dos médicos, a qual tende a se desfazer conforme o grau de escolaridade e o nível social dos pais seja mais alto, quando o desejado diálogo entre médicos e pais/responsáveis é a regra para se determinarem condutas clínicas com a criança. Nesse aspecto, Palhares \& Cunha (2013) refletiram sobre situações de conflito nos quais os responsáveis por crianças agridem os profissionais de saúde e concluíram que, sendo a infância tutelada, o pequeno paciente deve ser minimamente atendido e talvez tratado, se houver sinais de gravidade; o que se quebra é a relação entre o médico e os responsáveis pela criança, por exemplo, eximindo o médico de prescrever tratamentos domiciliares.

De todo modo, os adultos responsáveis pela proteção, cuidados e educação das crianças são sobremaneira expostos a pressões sociais de toda ordem. Conforme Patias et al.(2013), um adulto com um bebê no colo encontra-se em particular situação de vulnerabilidade, de modo que a parentalidade bem equilibrada necessita também de um suporte social-familiar. Ou seja, face a uma situação de estado clínico crítico da criança, há desarranjos e rearranjos de toda ordem dentro da família, de modo que a própria criança estará ainda mais vulnerável se seus adultos responsáveis se encontram em conflitos entre si e dificuldades sócio-econômicas. 
Guimarães \& Novaes (2005) levantam que a criança desenvolve autonomia aos poucos, conforme seu crescimento, desenvolvimento e amadurecimento, e essa percepção está há muito tempo presente no arcabouço jurídico, que classifica os menores em incapazes, parcialmente capazes e plenamente capazes. O arcabouço jurídico permite inclusive categorizar adultos como sendo incapazes em situações específicas, por exemplo diante de doenças que perturbem o bom funcionamento cerebral, tanto aquelas decorrentes de lesões físicas como as disfunções psíquicas graves. Conforme Figueiras (2010), o indivíduo é considerado legalmente plenamente capaz em idades que variam, mundo afora, de 12 a 21 anos. Segundo a Convenção das Nações Unidas sobre os Direitos da Criança de 1989, as crianças que forem capazes de formar e expressar opiniões devem ser ouvidas e suas posições devem ser ponderadas de acordo com sua idade e grau de maturidade, sobretudo diante de processos judiciais ou administrativos. No âmbito da pesquisa clínica, o consentimento do adulto responsável é documento essencial para a participação na pesquisa. Os direitos da criança são tutelados, conforme Gaiva (2009), no sentido que pesquisa clínica em crianças só devem ser feitas se os protocolos de pesquisa puderem beneficiá-las diretamente. Em outras palavras, o valor intrínseco da pesquisa clínica não é simplesmente a autonomia, mas a beneficência. Constantino \& Hirschheimer (2005), juntamente com Gaiva (2009), defendem que o menor, principalmente o adolescente, deve ser ouvido antes de ser submetido a uma pesquisa clínica. Esse princípio foi positivado, no Brasil, na Resolução 466/12 do Conselho Nacional de Saúde que traz a necessidade do termo de assentimento para pesquisas em menores de idade. Assim, se a criança ou o adolescente já forem capazes de se expressar claramente, uma pesquisa clínica necessita do termo de consentimento dos pais ou responsáveis e do termo de assentimento do menor. Sem esses dois documentos, a pesquisa é considerada como sendo antiética.

No caso do Brasil, o indivíduo apresenta, capacidades jurídicas crescentes dos 14 aos 21 anos: aos 14, para o trabalho como aprendiz; aos 16 como eleitor; aos 18 como penalmente responsável e livre para o trabalho e aos 21 como civilmente independente para contrair matrimônio. Leone (2009) levanta que as pessoas adquirirem capacidade sexual e reprodutiva ao redor dos 11 aos 13 anos de idade, portanto, enquanto são juridicamente incapazes. Assim, a mãe menor de idade revela dramas bioéticos evidentes, ainda mais se o pai também for menor: são pessoas que legalmente deveriam viver sob a tutela de um adulto, mas que ao mesmo tempo são responsáveis de seus bebês, de quem 
se espera o intuito de cuidar dos melhores interesses do recém-nascido. Surgem, por exemplo, questões peculiares: a adolescente gestante é respeitada em sua autonomia durante as consultas de pré-natal e parto. Mas assim que o neném vem ao mundo, existem, na prática, exigências para que uma pessoa maior de idade acompanhe mãe e bebê para a alta hospitalar.

Leone (2009) esclarece que a evolução de total dependência do recém-nascido até a total independência do adulto não ocorre aos saltos, mas em um processo contínuo que, embora siga etapas estereotipadas, varia em cada indivíduo no que tange ao ritmo de amadurecimento e aquisição de habilidades, dependendo sobremodo do ambiente sociocultural no qual o indivíduo se desenvolve. Ou seja, o reconhecimento que um indivíduo chegou à plena capacidade autônoma é um processo socialmente difuso e impreciso que se cristaliza, conforme Diniz (2006), em ritos de passagem. No arcabouço jurídico atual, não há ritos marcados, mas apenas a simples passagem do tempo: teria um jovem de 17 anos e 10 meses substancial diferença biopsíquica em relação aos 18 anos completos? Se do ponto de vista jurídico, a simples passagem do tempo pode ser considerada suficiente, na prática bioética do atendimento clínico a resposta é mais complexa: quais são os sinais, qual é a estrutura de raciocínio, intelecção e interação que indica ao profissional de saúde que aquele jovem indivíduo possui autonomia a ser respeitada?

Mesmo que o profissional esteja diante de indivíduos legalmente adultos, Guimarães \& Novais (2005) elencam uma lista de situações de flagrante redução de autonomia: presidiários, recrutas militares, imigrantes ilegais, refugiados políticos, turistas estrangeiros, dentre várias outras. Ou seja, a Bioética descreve a dicotomia entre autonomia e vulnerabilidade, ambas vistas como decorrentes do contexto social, das forças políticas e econômicas, da posição do indivíduo dentro de um subgrupo social e do subgrupo social dentro do grupo social maior do Estado (Almeida \& Machado 2010). Ou seja, discute-se a autonomia e a vulnerabilidade da criança, quando se sabe que os próprios adultos encontram-se em meio a situações de incerteza. De toda forma, Diniz (2006) conclui que não há como evitar a heteronomia de bebês e crianças pequenas. $\mathrm{Na}$ maior parte dos casos, são os pais que tomam as decisões pelas crianças. Nas situações de exceção, as quais, como já dito, não são raras, a equipe de saúde assume a responsabilidade imediata das decisões quando, conforme Figueiras (2010), haja risco iminente de morte, tempo escasso, e evidente benefício ao pequeno paciente. 
Almeida \& Machado (2010) relembram que muitas vezes a afronta à autonomia do paciente provém de todo o sistema de atendimento à saúde, não apenas exclusivamente do tipo e do atendimento profissional. Segundo os autores, em serviços com desbalanço da relação oferta/procura, onde haja sobredemanda profissional, é mais nítida a tendência ao paternalismo. Para esses autores, rejeitar o princípio da autonomia é rejeitar o princípio da dignidade humana e dos direitos humanos, mas isso não significa que autonomia seja tomada de forma absoluta, mas sim como um valor a ser desenvolvido dentro das especificidades de cada caso.

Gomes (2010) observa que as doenças que causam morte em crianças possuem apresentação clínica e curso distinto dos adultos. Floriani (2010) observa que no campo pediátrico, a atual conjuntura biomédica fez surgir a figura da criança dependente de tecnologia, ou seja, de crianças que vivem cronicamente doentes, vivendo e se desenvolvendo mediante uso contínuo de algum dispositivo que compense a perda de alguma função vital. Essas crianças crescem necessitando de cuidados especializados de forma contínua e intensiva. Como exemplos, o autor cita o uso de ventilação mecânica, de nutrição parenteral, de diálise. Via de regra, esses pequenos pacientes tornam-se dependentes de cuidados continuados por seus pais, com comprometimento emocional significativo. Embora no âmbito hospitalar sejam pacientes conhecidos, o autor afirma haver poucos estudos de cunho epidemiológico que mostrem o impacto social desses pacientes.

No campo pediátrico, tem havido a expansão do conceito de cuidados paliativos e de limitação terapêutica. Lacerda (2012) chama atenção que a questão dos cuidados paliativos é um debate que a Pediatria terá que enfrentar nos próximos anos e que existe confusão conceitual entre cuidados paliativos, limitação terapêutica e cuidados de pacientes terminais. Capelas (2009) esclarece que os cuidados paliativos são um conjunto holístico de cuidados tanto ao paciente como a seus familiares e amigos, enquanto os cuidados de pacientes terminais envolvem limitação terapêutica a fim de não se incorrer em obstinação terapêutica. De todo modo, os Cuidados Paliativos pediátricos se desenvolvem em centros de atendimento de maior complexidade, mas são os serviços de cuidados básicos que dão suporte e o atendimento imediato ao paciente. Floriani (2010) distingue entre condições clínicas limitadoras da vida e condições ameaçadoras à vida: as condições limitadoras são doenças sabidamente progressivas, com prognóstico de terminalidade passível de ser estimado estatisticamente com base em casos anteriores. As 
condições ameaçadoras são aquelas para as quais há tratamento de cura ou então de suporte prolongado, nas quais a doença em si cursa cronicamente, mas são as diversas intercorrências clínicas que podem evoluir de forma grave e fatal.

No âmbito familiar, os pais ou responsáveis por esses pacientes comumente se sentem fatigados e sobrecarregados. Muitas dessas crianças chegarão à idade adulta ainda totalmente dependentes de cuidados e ocasionalmente podem se tornar órfãs, pelo próprio ciclo vital de seus pais. Nesses casos, quem serão seus responsáveis legítimos? Trata-se, portanto, de uma situação-limite de heteronomia na qual as novas responsabilidades devem ser definidas. Quando os pais se colocam entre as crianças e o sistema de saúde, existe a tendência bioética de considerá-los, dentro de certos limites, como seus legítimos representantes, mas em caso de adoecimento e morte dos pais, provavelmente esses pacientes serão institucionalizados, o que significa que há diretrizes éticas gerais a serem adotadas. Esses limites éticos são mais evidentes, conforme Salinas et al. (2011), no contexto da neonatologia: os recém-nascidos prematuros ou doentes são pacientes sob risco iminente de morte e de sequelas, de modo que o poder de decisão sai da família e recai sobre a equipe médica. Salinas et al. (2011) refletem sobre o caso de prematuros no limite da viabilidade e concluem que, conforme a idade gestacional, os cuidados intensivos serão prestados ou então serão considerados como obstinação terapêutica, mas que, sobretudo, essa decisão é heterônoma e quem toma não são os pais, mas a equipe médica. O que respalda, juridicamente, essa situação de heteronomia, são os protocolos e diretrizes clínicas emitidas pelas sociedades da especialidade médica, que periodicamente revêem suas posições conforme o avanço tecnológico: a idade considerada viável para o prematuro tem se tornado cada vez menor.

Não obstante, em situações clínicas de terminalidade de vida no período neonatal, a equipe médica mostra-se muito inquieta e incapaz de estabelecer diálogos compreensivos com a família, no tocante, por exemplo, à limitação terapêutica (Salas et al. 2008). Kipper \& Hossne (1998) ressaltam que justamente nesses casos mais extremados e conflituosos, a existência de comitês de bioética ou de ética médica ou de ética clínica podem ajudar a estabelecer diálogos em campos neutros de discussão; os comitês não tomam decisões, mas orientam que decisões tomar, baseadas no amplo e franco diálogo. Conforme Diniz (2006) ressaltou, pais esclarecidos distinguem as sutilezas de tratamentos dolorosos de obstinação terapêutica: a diferença está em algo abstrato, que é a expectativa de cura. Se há chances de cura, então, determinados tratamentos podem ser considerados como 
'tratamentos dolorosos' e que portanto devem ser realizados; se não há chances de cura nem perspectiva de melhora clínica, tratamentos dolorosos se traduzem em tortura, ou, eufemisticamente, obstinação terapêutica.

Gomes (2010) concorda com Garrafa \& Albuquerque (2001) que a comunicação é etapa ética essencial no contexto de Cuidados Paliativos e de cuidados a pacientes terminais. Uma grande questão é: para as crianças em fase terminal, qual seria o momento mais adequado para falar em morte? Segundo Gomes (2010), aparentemente, os pais que falam em morte com os filhos conseguem se sentir menos culpados e inclusive, conforme diz Salinas (2011), se surpreendem que as crianças parecem aceitar a iminência de morte com mais rapidez do que os adultos. De forma inversa, os pais que tentam esconder a todo custo da real situação da criança tendem a vivenciar um luto mais prolongado. Garrafa \& Albuquerque (2001), contudo, levantam que no contexto de desigualdade social da América Latina, os pais de pacientes outorgam à equipe médica a responsabilidade da decisão e procuram mais obter atenção e perceber que a equipe considera o seu caso particular como relevante, do que propriamente as decisões profissionais no âmbito técnico.

O mais importante, em conclusão, é, independentemente do grau de independência que a criança/adolescente possuir, ser sempre tratada com dignidade e respeito, não se admitindo nem a negligência nem a obstinação terapêutica, resgatando-se e estimulandose decisões autônomas e esclarecidas por parte do adolescente sempre que possível. São os pais e os entes familiares as pessoas mais profundamente envolvidas, inclusive emocionalmente, com o bem-estar e o melhor para a criança, mas o fato de a infância ser tutelada pelo Estado significa que há limites ao pátrio poder e que a ação dos profissionais de saúde devem estar pautadas por diretrizes ético-científicas de atuação. 


\section{PARTE II - REVISÃO SISTEMÁTICA E ESTUDO DE CASOS}

1 - Revisão Sistemática de Literatura

\section{Introdução}

Conforme França \& Azevêdo (2010), o método teórico-conceitual objetiva desenvolver conhecimentos pela confrontação de pensamentos, conceitos e fundamentos já constituídos e, no campo da Bioética brasileira, é o método que tem sido utilizado por mais de $80 \%$ das publicações.

Segundo Marconi \& Lakatos (2012), a pesquisa bibliográfica sistemática oferece meios para definir e resolver problemas elencados como também para explorar áreas onde as discussões não se consolidaram. Nesse sentido, a pesquisa bibliográfica não é mera repetição do que já foi publicado, mas sim um modo de reexaminar o assunto por novos ângulos e abordagens distintas.

Assim, a situação descrita na fundamentação mostra que os Cuidados Paliativos em sua expressão mais contundente, que é a evolução do câncer. No entanto, outras condições crônicas apresentam, estatisticamente, o mesmo impacto na mortalidade em cinco anos que o câncer, como insuficiência cardíaca, doença pulmonar obstrutiva crônica, demências, etc.

Na faixa etária pediátrica, as doenças crônicas 'não-câncer' são, cada uma delas, relativamente infreqüentes, mas em seu conjunto são suficientemente prevalentes para que haja demanda aos serviços de saúde em responder acerca de um posicionamento ético sobre limitação terapêutica.

Dentre esses casos, existem as malformações cerebrais, que na faixa etária pediátrica se coexpressam com o crescimento somático e do desenvolvimento neuropsicomotor, ainda que em ritmo e de modo distinto das crianças neurologicamente sadias. Dessa forma, é preciso verificar como tem sido tratada a questão de Cuidados 
Paliativos e de limitação terapêutica para tais situações, ou seja, como tem sido (ou não) evitada a obstinação terapêutica acerca desse grupo de pacientes.

\section{Objetivos}

\section{Objetivo Geral}

Analisar as peculiaridades na abordagem dos Cuidados Paliativos e da limitação terapêutica na assistência à saúde de crianças portadoras de malformações cerebrais.

\section{Objetivos Específicos}

1. Identificar as principais intervenções terapêuticas invasivas na assistência à saúde de crianças portadoras de malformações cerebrais.

2. Delimitar a diferença ética e conceitual entre cuidados essenciais e obstinação terapêutica na assistência à saúde de crianças portadoras de malformações cerebrais.

3. Analisar os limites bioéticos das decisões dos responsáveis perante a heteronomia das crianças portadoras de malformações cerebrais

\section{Metodologia}

A pesquisa bibliográfica, segundo Marconi \& Lakatos (2012), didaticamente se subdivide nas etapas a saber: identificação das fontes, localização, compilação e fichamento. A identificação é a fase de reconhecimento do assunto, com base nos catálogos; a localização é a obtenção dos textos, enquanto a compilação e o fichamento 
são, respectivamente, as etapas de transcrição e ordenamento sistemático das informações.

Considerando essas etapas, para a identificação das fontes foram buscados artigos em periódicos por conterem os avanços e as discussões atualizadas do pensamento bioético acerca dos Cuidados Paliativos e da limitação terapêutica na assistência de final de vida de crianças portadoras de malformações cerebrais. A literatura foi identificada com base nas obras de referência a seguir: o ISI Web of Science, a BIREME, a base Scielo e o Google Scholar. Em seu conjunto, essas bases contam com mais de 12 mil periódicos, indexando os de maior impacto. Foram selecionados os artigos publicados em inglês, português e espanhol.

Inicialmente, a busca foi feita mediante o cruzamento das palavras-chave 'ethics' 'palliative care' 'child', com o retorno no total de mais de vinte mil possíveis referências. Dessa forma, acrescentou-se 'and not cancer', uma vez que o foco do trabalho são justamente outros casos que não o câncer. Com isso, foi feito o cruzamento das referências levantadas em cada base, que foram listadas e buscadas nas fontes de acesso aberto: Periódicos Capes, Research Gate, além de busca direta pela ferramenta Google.

De cada fonte consultada, foi feito um fichamento extraindo-se os dados sobre:

a) a situação-problema, isto é, a doença de base que sustentou o cuidado paliativo na criança

b) os tratamentos e procedimentos que foram considerados como obstinação terapêutica

c) os conflitos de responsabilidade profissional levantados

d) os limites bioéticos do exercício da heteronomia do adulto responsável

e) menção sobre as conseqüências e limites éticos e jurídicos da indicação de cuidados paliativos.

Os dados foram mutuamente confrontados, de modo a revelar consensos e antagonismos entre o pensamento/fundamentos/conceitos/paradigmas dos autores. As 
referências foram citadas por entrada do tipo autor-ano no Estilo Vancouver conforme Rodrigues (2008).

\section{Resultados}

O levantamento bibliográfico sistemático mostrou 119 artigos, dos quais 78 foram passíveis de acesso em fontes públicas - periódicos capes e researchgate (Quadro 1). Com a metodologia de restrição do termo de busca 'cancer', os textos que analisaram casos clínicos específicos foram concentrados em problemas neurológicos, mostrando como a questão neuroética é um tema acirrado no âmbito dos cuidados paliativos pediátricos: casos: Síndrome de Down associada a encefalopatia degenerativa (Leewenburg-Pronk et al. 2015), insuficiência respiratória por hemossiderose pulmonar (Hirani \& Rahman 2012), atrofia muscular espinhal (Powell 2007, Garcia-Salido et al. 2015), transplante renal e coma persistente por lesão acidental (Levine 2001), distrofia muscular de Duchenne (Geller et al. 2012, Penner et al. 2010), coma persistente por lesão acidental junto com neoplasia cerebral (Gunn et al. 2004), erro inato de metabolismo com coma persistente (Morrison \& Berkowitz 2007), trissomia do $18 \mathrm{com}$ defeito cardíaco operável (Liben et al. 2008), fibrose cística terminal (Liben et al. 2008), insuficiência cardíaca grave por cardiopatia inoperável (Clark \& Dudzinski 2013), paralisia cerebral grave (Ambler 2014), síndrome de Proteus (Turner 2010).

Os artigos sistematicamente levantados permitiram a análise de um panorama concreto e cotidiano dos conflitos bioéticos concernentes aos cuidados paliativos quando esses se tornam o tratamento-padrão, ou seja, associados à limitação terapêutica. A limitação terapêutica é, portanto, o extremo dos cuidados paliativos e a situação na qual os conflitos bioéticos se tornam mais evidentes. Essencialmente, a base ético-jurídica para a problemática, segundo Lago et al. (2007), reside no fato que os cuidados médicos de final de vida tornaram-se uma questão de saúde pública.

Houve consenso nos trabalhos que o dilema ético acerca da limitação terapêutica surge concomitantemente ao grande progresso da tecnologia biomédica. A situação de inércia para o médico e para o arcabouço jurídico termina sendo o de fazer uso indiscriminado de toda a tecnologia existente, a despeito dos efeitos deletérios - duplo efeito - inerente às tecnologias de suporte vital, principalmente as mais invasivas. Nesse 
ponto, Sayeed (2005) ilustra que leis mal redigidas e em dissonância com a realidade da prática clínica terminam por engessar a solução de problemas sérios.

Mercurio et al. (2014) classificam os países em: cor verde, onde a legislação é explícita em reconhecer a necessidade de limitação terapêutica; cor amarela, na qual a situação é indefinida, mas com tendência à aceitação de limites; cor vermelha, na qual qualquer discussão a esse respeito é rechaçada. No mais, os cuidados paliativos pediátricos, segundo Downing et al. (2016), mundo afora, são esquecidos ou negligenciados. Assim, o Brasil, com o recente Código de Ética Médica, encontra-se na cor amarela, ou seja, encontra-se em transição, enquanto, para fins comparativos, segundo Durall et al. (2012), na Rússia não se admite qualquer tipo de discussão ou abordagem sobre limitação terapêutica. Portanto, a maior parte das discussões bioéticas levantadas nessa revisão provém de autores de países nos quais a limitação terapêutica já encontra um corpo jurídico mais consolidado, de modo que os conflitos se mostram em um patamar elevado de complexidade.

Teoricamente, conforme Stayer (2012), Pelant et al. (2012), Cook et al.(2012), bons serviços de cuidados paliativos fariam que os cuidados médicos de final de vida evitassem internação hospitalar, isolamento, procedimentos invasivos. Mas Lago chama atenção que, na faixa etária pediátrica, os cuidados de final de vida são mais frequentemente realizados em Unidades de Terapia Intensiva, o que gera evidentes conflitos éticos, pois as UTIs são estruturadas para cuidados intensivos, quando os pacientes terminais necessitam de cuidados paliativos e limitação terapêutica. Nesse ponto, Ramnarayan et al. (2007) levantam que os adultos com previsão de finitude de vida tendem a escolher a morte no domicílio, mas a criança em situações de terminalidade tende a morrer em âmbito hospitalar, e, principalmente, em uma UTI, portanto, em uma condição de obstinação terapêutica. Justamente, conforme Rezzónico (2004), os cuidados de final de vida se baseiam na recusa à obstinação terapêutica, ou seja, ao emprego maciço de tecnologia mesmo diante do resultado previsível e esperado de óbito do paciente. Em tese, sonegam-se/suspendem-se tratamentos que sejam dolorosos e ineficazes (Ambler 2014, Zinner 2009), mas jamais o paciente é abandonado sem cuidados: deixam-se de empregar tecnologias avançadas, mas administram-se medicamentos de alívio de sintomas e mantêm-se cuidados básicos com os pacientes.

Morgan (2009) compara a recomendação para a limitação terapêutica em adultos, que por convenção difusa considera uma temporalidade estatisticamente previsível de 
óbito em 6 meses como condição inicial para a determinação de suspensão ou sonegação de tratamentos, mas que para a faixa etária pediátrica a comunidade médica ainda não posicionou um período numérico semelhante. Leewenburgh-Pronk et al. (2015) ressaltam que a heteronomia da criança se reveste, na verdade, de um caráter de tutela, na qual a infância deve ser protegida, inclusive da imaturidade e irresponsabilidade inerentes a esse período da vida. Quando esse valor essencial se defronta com o caso de uma criança sofredora de doença crônica e com curta expectativa de vida, os conflitos éticos e jurídicos acerca da limitação terapêutica refletem um choque de valores entre sacralidade da vida e qualidade de vida. Ambos são expressão de valores gerais e difusos e somente apresentam efeitos práticos diante de um caso concreto. Ou seja, segundo Geller et al. (2012), esse conflito se torna ainda mais acirrado quando se trata de crianças: qual valor prevalece; se um dia mais na vida de uma criança é algo inestimável ou até que ponto a qualidade dessa vida deve ser um contrapeso a ser considerado. Como exemplo, Klein (2009) mostra um caso de holoprosencefalia com uma intercorrência respiratória grave e ida prolongada à UTI, uma situação na qual a limitação terapêutica seria indicável, mas de modo inesperado, esse bebê apresentou boa recuperação pós-alta, e um bebê doente desenvolveu-se em um pré-escolar doente. Casos como esses levantam a questão acerca da expectativa de temporalidade para a limitação terapêutica: deveria ser proposta na perspectiva de morte em 6 meses, tal como a prática para os adultos tem sedimentado? Ou deve-se levar em conta outros fatores, como a probabilidade de sobrevivência até: dez anos, adolescência ou idade adulta?

Dos 77 artigos, 70 levantaram a discussão ético-jurídica acerca da diferença entre suspensão e sonegação de oferta de um tratamento. A conclusão teórica dos autores diz que eticamente suspender ou sonegar um determinado tratamento são equivalentes. $\mathrm{Na}$ percepção prática dos médicos e enfermeiros assistentes, além da população em geral, contudo, há diferenças grandes entre sonegar e suspender tratamentos. Tsai (2011) registra o senso comum que ao se suspender um tratamento, é possível saber quais foram os efeitos do tratamento e qual é a estimativa do óbito do paciente. Já a sonegação implica, na prática, a substituição de um tratamento mais invasivo e agressivo por outros existentes, ainda que menos eficazes.

Nesse aspecto, o estudo de Tan et al. (2006) consegue concretizar em termos matemáticos que tanto a percepção do senso comum como a reflexão ética estão corretos: os autores apresentam uma curva de Kaplan-Meyer de sobrevida dos grupos 
'sonegação' e 'suspensão' de tratamento: em uma fase inicial, ambos os grupos apresentam a mesma mortalidade, mas após essa fase inicial, o grupo 'sonegação' apresenta uma sobrevida maior que o grupo 'suspensão'. Ou seja, quando se suspende ou se sonega um determinado tratamento, o óbito será previsivelmente imediato no caso dos pacientes mais graves, mas uma proporção significativa pode sobreviver por um período indefinido - de poucos dias a várias semanas, e tais pacientes sobrevivem por mais tempo se ao invés de procedimentos intensivos e invasivos, recebem cuidados paliativos adequados. De todo modo, Klein (2009) frisa que, quando um tratamento é suspenso e o óbito demora a ocorrer, os pais tendem a se questionar sobre o fato se realmente o diagnóstico de terminalidade da vida estava correto e frequentemente voltam atrás no que tange a decisões de limitação terapêutica.

Quarenta e seis artigos mencionaram a questão do procedimento decisório acerca da limitação terapêutica. A questão da dependência da criança e de sua incapacidade de plena expressão - heteronomia - foi sempre aventada não como uma barreira à limitação terapêutica, mas sim como fator gerador de conflitos éticos singulares. Para fins comparativos, Cate et al. (2015) e Siegel et al. (2014) descrevem que a eutanásia infantil, legalizada na Holanda e também na Bélgica (Silva \& Nunes 2015) é um procedimento altamente judicializado, no qual a promotoria analisa o processo decisório quanto à exigência dos quesitos legais. Não se trata de uma análise de mérito, mas de constar que as etapas formais foram todas cumpridas. Frente a isso, Morrison \& Kang (2014) levantam que a decisão de limitação terapêutica em UTI, embora seja algo penoso, já se tornou corriqueiro e rotineiro, de modo que é um procedimento decisório que cabe à equipe médica assistente, que é quem conhece e vivencia detalhes do caso; dessa forma os comitês institucionais de ética são essenciais, mas seu papel é o de agir como instância revisora, para a intermediação de conflitos, quando houver.

Em todos os textos, é nítido o valor do diálogo com os pais o procedimento que legitima a limitação terapêutica. Também, em consenso, a iniciativa pela limitação terapêutica provém da equipe médica, em poucos casos essa iniciativa adveio dos pais. Em síntese, os textos descrevem que deve haver maneiras e condições adequadas de comunicação e tomada de decisão: primeiramente, a equipe assistente - médicos, enfermeiros, fisioterapeutas - devem, nas visitas diárias, concordar entre si que a limitação terapêutica é o melhor a ser feito para um dado paciente. Então, os pais da criança são convidados para reuniões com a equipe, a qual deve ser realizada em uma 
sala apropriada. Uma primeira reunião, é abordado o tema e dá-se tempo para os pais refletirem sobre a questão; em um segundo momento, é tomada a decisão de limitação terapêutica. Em alguns casos, os pais se sentem inseguros, de modo que pode ser necessário mais reuniões. Erichsen et al. (2010), Bovens (2015), Vose (1999) descrevem técnicas de comunicação aberta e honesta com os pais do paciente. Essa questão de comunicação vem sendo debatida desde pelo menos 1969, quando a própria Cecily Saunders (Evans \& Saunders 1969) confrontou a cultura da época frente ao óbito infantil: Evans descreveu que o médico apresentava uma reação emocional forte, improvisada, chegando a chorar junto com os pais que perdiam sua criança, enquanto Saunders enfatizava a necessidade de empatia, mas com distanciamento emocional, até mesmo para que o adequado suporte aos familiares fosse possível. $E$ mesmo atualmente, não apenas o profissional médico, mas o profissional de enfermagem, conforme Menin \& Pettenon (2015), necessita de saber lidar, emocionalmente, com a terminalidade de vida no contexto pediátrico, o que reforça a necessidade de as visitas clínicas em UTI contarem com a presença das categorias profissionais que assistem aos pacientes.

A limitação terapêutica não é medida intempestiva nem de urgência, mas uma decisão tomada em etapas frente a uma situação crônica de base. Ou seja, o médico, em situação crítica, tem o dever e a ampla liberdade de indiciar e iniciar tratamento, mas quando se trata de limitação terapêutica, o fato deve ser compartilhado e comunicado aos pais ou responsáveis pela criança. Assim, o espaço de reunião com os pais não se dá em uma única vez; na maioria das vezes, uma primeira comunicação é feita, a equipe marca uma segunda reunião na qual a decisão de limitação terapêutica é, então, tomada. A partir desse aspecto, na literatura, a tradição estadunidense adota uma postura distinta da tradição francesa: nos EUA, a limitação terapêutica é legalizada, mas profundamente arraigada no contrato feito com os pais: a ordem de não-reanimação, por exemplo, é um documento expressamente assinado pelos responsáveis. Na França e no Japão, a limitação terapêutica segue a lógica da não-objeção, ou seja, a equipe médica propõe limitação terapêutica, a qual é implementada no caso de não haver objeção por parte dos pais. Para Lago et al. (2007) e também Clark \& Dudzinski (2013), diante da fragilidade emocional que as famílias vivenciam, essa postura mais paternalista por parte da equipe médica é vista como uma forma de aliviar o peso da decisão de cima dos pais e transferir para a equipe de saúde, de modo que os pais não sintam, futuramente, que eles tomaram a decisão da morte da criança. 
A iniciativa médica em propor a limitação terapêutica será tanto mais segura e precisa quanto mais houver diretrizes mais esclarecidas quanto ao curso clínico natural das doenças e os indícios clínicos que apontem para uma condição clínica de terminalidade instalada (Brook \& Hain 2008). Feudtner \& Nathanson (2014) chamam atenção que dados estatísticos consolidados podem guiar protocolos e diretrizes, mas que na prática, não é possível prever como será a evolução daquele paciente específico, ou seja, o exercício de prognóstico é essencialmente intuitivo, e daí que pelo princípio da incerteza, não se pode deixar de haver aberto e amplo diálogo com os responsáveis pelo paciente. Ou seja, cuidados paliativos são um tópico de pesquisa de ponta e Cadell et al. (2009) ressaltam a importância inclusive de pesquisas multicêntricas em cuidados paliativos, o que, diante da delicadeza da situação, tem ressaltado que mesmo os comitês de ética em pesquisa mostram posições muito distintas acerca dos protocolos existentes.

Aliás, foram as pesquisas sistemáticas que clarificaram alguns mitos acerca da sedação profunda nas fases terminais da doença: Tan et al. (2006) e Morrison \& Kang(2014) reviram na literatura que, embora teoricamente altas doses de analgésicos e sedativos possam inibir o centro respiratório, o grupo dos pacientes que receberam doses mais altas sobreviveram por mais tempo que o grupo para os pacientes a quem doses mais altas foram sonegadas. Nas palavras desses autores, a pesquisa em cuidados paliativos propiciou o surgimento de diretrizes de sedação e analgesia que escalonam a dose, ou seja, iniciam-se doses mais baixas e aumenta-se aos poucos conforme a necessidade do paciente; com esse tipo de escalonamento, doses altas de medicamentos analgésicos e sedativos podem ser usados nos pacientes que assim o necessitarem sem que paire algum tipo de desconfiança a respeito de uma eventual redução de sobrevida.

A situação dialógica entre o protocolo médico e a heteronomia da criança, representada pelos seus pais, tem gerado conflitos éticos, discutidos na literatura. Um primeiro tipo de conflito diz respeito a pais que desejam novos tratamentos contra a indicação médica: no caso descrito por Ham (1999), os pais queriam tentar um segundo transplante de medula, no que os médicos objetavam, e nas cortes judiciais inglesas foi dada razão ao protocolo médico, que considerava tal medida como futilidade e obstinação. Feltman et al. (2014) descreve um caso particular de comorbidades graves: prematuridade extrema com onfalocele, no qual os pais pediam insistentemente para que 
o bebê fosse reanimado e operado e a equipe médica previa que isso não seria factível. Esses casos revelaram que não iniciar um tratamento por falta de indicação médica ou condições clínicas tende a ser ética e juridicamente favoráveis à decisão médica, ou seja, que sonegar tratamentos é mais aceitável do que suspender tratamentos.

Outro tipo de conflito é exatamente o oposto: quando os médicos indicam a suspensão ou redução de tratamentos e os pais desejam a manutenção dos cuidados. Como consenso, esse não é um conflito que é considerado apenas em uma ou poucas reuniões da equipe médica com os pais ou responsáveis, mas sim quando surge de forma sistemática. Ou seja, a proposta de limitação terapêutica não deve ficar para o último momento, mas ser construída no planejamento de médio prazo conforme haja sinais de deterioração clínica progressiva e irreversível. Para esses conflitos, Morgan (2009), Durall et al. (2012), Frader \& Michelson (2007), Basu (2013) consideram que uma instância ética revisora pode ser acionada e, em casos extremos, solicitação ao judiciário. Não obstante, Powell (2007) ainda defende que, embora uma limitação terapêutica não seja formalmente aceita, também não há a obrigação médica de indicar procedimentos invasivos, como coletas seriadas de amostra sanguínea, monitoração por eletrodos (os quais requerem certo imobilismo do paciente), balanço hídrico por sondagem vesical, etc.

Nesse quesito, o pensamento jurídico varia nos diversos países do mundo: Okhuysen-Cauley et al. (2007) e também Ruppe et al.(2013) descrevem a tendência, nos EUA, de obrigar os médicos a realizarem os procedimentos caso o paciente não concorde expressamente com a limitação terapêutica, a não ser em situações específicas muito bem referendadas por protocolos já existentes, como neoplasia terminal ou prematuridade extrema (Torres et al. 2013). Já no Reino Unido, segundo Ham (1999) e também Wilfond (2014), a tendência geral é a de seguir os protocolos dos médicos caso as equipes de diversos serviços mostrem consenso sobre a futilidade terapêutica. Gunn et al. (2004) mostrou uma situação-limite de tumor cerebral mas que por intercorrência respiratória resultou em estado vegetativo prolongado: a postura norte-americana foi mais contundente em suspender os tratamentos mesmo à revelia dos familiares do que os representantes de outros países - Singapura, Japão, Alemanha e Rússia. Segundo as observações de Schildman et al. (2011), a Alemanha encontra-se ressabiada com as práticas de limitação terapêutica, que foram usadas de forma abusiva durante o Nazismo, de modo que há maior facilidade em não progredir com tratamentos do que propriamente suspender algum tipo de suporte. De todo modo, no geral, as equipes médicas não 
realizariam suspensão terapêutica de tratamentos enquanto os familiares não concordassem e não absorvessem o choque que, naquele caso, embora a morte fosse esperada, eles não queriam que fosse tão imediato, e ainda mais por uma intercorrência que aparentemente nada tinha a ver com a doença de base.

Quando se defrontam os casos reais, os valores éticos subjacentes à problemática tornam-se mais nítidos: nos textos analisados, embora as palavras de Feltman et al. (2014) digam que qualquer tratamento pode ser discutido com respeito à suspensão ou sonegação, os conflitos mais drásticos de decisão ética recaem sobre suporte respiratório/ventilação mecânica e nutrição enteral por sonda e cada um deles apresenta aspectos éticos peculiares.

O suporte avançado por ventilação mecânica via intubação orotraqueal é um tratamento muito invasivo e doloroso, que frequentemente necessita de sedação e analgesia potente para ser instituído ou mantido. Não obstante, a suspensão de ventilação mecânica usualmente leva o óbito em pouco tempo, trazendo, portanto, o questionamento sobre qual seria o limite entre limitação terapêutica e eutanásia. Nesse questionamento, Morrison \& Kang (2014) e também Rapoport et al. (2013) chamam atenção que, como limitação terapêutica é um fato novo, é preciso inclusive que se crie um vocabulário que consiga descrever, abstratamente, as nuances das situações clínicas vivenciadas.

Geller et al. (2012) descrevem que o suporte respiratório apresenta possibilidades menos drásticas e invasivas do que a ventilação mecânica: é possível um suporte nãoinvasivo, ou mesmo suporte ventilatório via traqueostomia ao invés de intubação orotraqueal. Esses autores listam as possibilidades de limitação terapêutica de suporte respiratório: a) não iniciar nenhuma medida nesse sentido; b) não realizar intubação orotraqueal; c) restringir-se a suporte via traqueostomia, se o paciente já possuir uma; d) restringir-se a suportes não invasivos; e) iniciar ventilação mecânica por um período prédeterminado, findo o qual o paciente será extubado.

Garros \& Rosychunk (2003), Levine (2001), Geller et al. (2012) reconhecem que há nítida futilidade clínica quando o órgão tratado está falindo a despeito da tecnologia empregada; no caso, portanto, da ventilação mecânica no contexto de cuidados de fim de vida, se os parâmetros ventilatórios se mostram prolongadamente elevados e ainda assim os parâmetros clínicos são de insuficiência respiratória, não há eutanásia na suspensão da ventilação mecânica, e sim há, claramente obstinação terapêutica em 
manter a vida do paciente por um fio que previsivelmente se romperá em breve às custas de um tratamento invasivo e doloroso. Vose (1999) considera que essa situação é uma situação de futilidade fisiológica, mas que a futilidade terapêutica pode se referir também ao conjunto do quadro clínico do paciente, ou seja, quando cada suporte avançado é feito em parâmetros habituais, mas a condição do paciente é de nítida deterioração progressiva, como no caso de doenças neurodegenerativas. Frader \& Michelson (2007) adicionam que, em um contexto de cuidados de fim de vida, se a sedação profunda por aplicada por conta da ventilação mecânica em si e não por conta da condição clínica de base do paciente, é um critério indicador que a situação vivenciada é de obstinação terapêutica.

O suporte respiratório apresenta nuances em que não fica claro se houve apenas limitação terapêutica ou a determinação da morte do paciente naquele momento: Torres et al. (2013), Feltman et al. (2014), Vose (1999) descrevem o interdito da aplicação de bloqueadores neuromusculares à extubação do paciente porque, obviamente, com o músculo diafragma paralisado, a morte é causada pelo fármaco e não pelo medicamento. Nesse ponto, Morrison \& Berkowitz (2007) definem que o termo eutanásia somente é possível de ser referido quando medicações letais são administradas nos períodos intercríticos do paciente. Torres et al. (2013) descrevem que a extubação no contexto de cuidados paliativos é precedida da suspensão de relaxantes musculares, do aumento da dose de sedativos, da redução dos parâmetros ventilatórios até a extubação e a substituição por outro suporte menos invasivo, como uma pronga nasal de oxigênio. No entanto, Penner et al. (2010), estudando um caso de distrofia muscular de Duchenne, mostra que não é claro se ventilação mecânica domicilar por traqueostomia é obstinação terapêutica ou se é apenas cuidado crônico diante dessa doença grave e previsivelmente fatal. Nesse sentido, Feltman et al. (2014) e Wilfond (2014) levantam que os cuidados menos invasivos - como traqueostomia ou gastrostomia - não são a priori obstinados, mas eles por si podem exigir cuidados e gerar novas complicações - e tais intercorrências associadas a esses procedimentos podem indicar uma situação de obstinação terapêutica. Igualmente, o caso do paciente descrito por Leewenburgh-Pronk et al. (2015) mostra como pode ser tênue a distinção entre limitação terapêutica e eutanásia: o paciente se mantinha estável, porém grave, com o mero uso de oxigênio nasal por cateter, o qual, quando foi retirado, trouxe o óbito do paciente em poucas horas. 
A questão neuroética é de particular importância no conflito decisório acerca da suspensão de suporte respiratório: frente aos pacientes com graves sequelas cognitivas (malformações cerebrais, coma persistente, paralisia cerebral, etc.), Feudtner \& Nathanson (2014), Diekema et al. (2009), Piva et al. (2011), Devictor \& Latour (2011), os médicos se sentiriam menos desconfortáveis em indicar suspensão e sonegação de tratamentos do que frente a doenças terminais não-oncológicas que não afetem o cognitivo, como doenças musculares neurodegenerativas (Tan et al. 2006, Penner et al. 2010, Garcia-Salido et al. 2015), fibrose cística (Liben et al. 2008), insuficiência pulmonar por hemossiderose (Hirani \& Rahman 2012), etc.

No entanto, com relação a cromossomopatias e/ou malformações cerebrais, Ambler (2014) e Wellesley \& Jenkins (2009) defendem que o diagnóstico por si só não é suficiente para a indicação de limitação terapêutica, pois são doenças cuja expressão clínica pode ser de intensidade variada, desde leves sintomas até graves problemas que geram uma situação de dependência de tecnologia. Os pacientes portadores com alguma frequência apresentam períodos de estabilidade clínica. Em uma perspectiva temporal, Feudtner (2007) apresenta uma ilustração da condição clínica ao longo do tempo desses pacientes: a terminalidade começa a se evidenciar quando: a) após uma internação em UTI, o estado clínico geral não retorna ao nível anterior (alta estável, mas com sequela); b) começa a haver intercorrências clínicas graves recorrentes.

Com relação à nutrição ou hidratação por sondagem nasogástrica ou gastrostomia, para, Diekema et al. (2009), Floriani (2010), Ambler (2014), a nutrição somente é um cuidado essencial se o paciente apresenta capacidade de deglutição ou a perspectiva de retomar tal capacidade. Assim, no caso de estado vegetativo persistente, a visão inglesa e norte-americana é no sentido de deixar a definição a cargo dos responsáveis, ou seja, os médicos não indicam a suspensão desse cuidado, mas caso seja do pedido dos responsáveis, a nutrição por sondagem é suspensa, enquanto aumentam-se as doses de sedativo e aguarda-se o óbito por desidratação. Leewenburgh-Pronk et al. (2015) analisam que, geralmente, os pais pedem a suspensão da nutrição porque a condição clínica geral dos cuidados é muito penosa, não que o suporte nutricional em si traga aparentes mal-estares ao paciente. Morrison \& Kang (2014) mencionam que a nutrição pode ser suspensa caso ela traga danos ao paciente; Hidayat et al. (2015) descrevem o caso de uma menina com câncer terminal que sentia muita fome e desejo de se alimentar, mas sempre que o fazia, sofria em seguida com vômitos incoercíveis que a 
desidratavam. Embora seja um evento corriqueiro nos Estados Unidos, segundo Wellesley \& Jenkins (2009), pelo menos metade dos médicos norte-americanos não concorda que a retirada de nutrição artificial seja uma limitação terapêutica eticamente aceitável, e DeVictor \& Latour (2011) mostra que, nos países europeus, pode haver a tendência de não se iniciar nutrição artificial em casos específicos, se houver concordância dos responsáveis, mas raramente a proposta de retirada de nutrição.

Por fim, Floriani (2010) e Vose (1999) afirmam, com relação aos custos financeiros do atendimento a paciente terminais, que não é possível afirmar que o dinheiro que não se gastou com um determinado paciente irá necessariamente para outro que necessite de algum tratamento. O custo em saúde é um custo global, de modo que casos particulares não geram impacto financeiro significativo ao sistema.

\section{2 - Estudo de casos}

\section{Introdução}

Os casos a seguir relatados são casos reais e advindos da experiência profissional pessoal do autor. As situações são verídicas e foram extraídas apenas as informações gerais mais relevantes para a discussão ética a respeito de cuidados paliativos ou limitação terapêutica, de modo que não há nenhum dado apresentado que eventualmente venha a identificar qual foi o paciente em questão, até mesmo porque mais de um paciente pode ter perpassado pela mesma história clínica.

\section{Casos}

Caso $n^{\circ}$. 1. (Mistanásia). Recém-nascido a termo do sexo masculino, de parto vaginal, com diagnóstico prévio de anencefalia. Por questões pessoais, a mãe insistiu e levou a gestação a termo. O parto teve início espontâneo com 39 semanas. Ao nascimento, o bebê mostrou estímulo respiratório e chorou fraco. Não conseguiu sugar ao seio materno, mas foi possível nutri-lo mediante uso de copinhos. Permaneceu no domicílio, até que com 40 dias de vida, iniciou quadro febril, tendo procurado pronto-socorro. Realizou exames que indicaram uma infecção urinária. Enquanto se aguardava o resultado da urocultura, foi internado para o uso de ceftriaxona. No dia seguinte, o plantonista que examinou a criança 
determinou que, pelo fato de o neném ser anencéfalo, não havia sequer indicação de tratamento da infecção urinária e deu alta para a criança com cefalexina. No dia seguinte, a mãe procurou outro pronto-socorro, com o bebê em francos sinais de sepse, tendo ido a óbito cerca de três horas após a entrada nesse outro serviço, onde recebera expansão volêmica, ceftriaxona e oxigênio por cateter. No dia seguinte, o resultado da urocultura desse recém-nascido evidenciou Klebsiella pneumoniae resistente a carbapenêmicos.

Caso $n^{\circ}$ 2. (Obstinação terapêutica). Recém-nascido a termo, do sexo feminino, com diagnóstico prévio de mielomeningocele. A mãe tinha apenas o primeiro grau completo e, embora tenha feito as consultas pré-natais, sabia apenas genericamente que o bebê viria com problemas. O parto foi cesariana com 37 semanas gestação por conta de ruptura de membranas e desproporção céfalo-pélvica. Ao nascimento, apresentou perímetro cefálico de $45 \mathrm{~cm}$ (média normal é de $35 \mathrm{~cm}$ ) e mielomeningocele. Encaminhado para procedimento cirúrgico, foi posta válvula de derivação ventrículo-peritonial e corrigida a mielomeningocele. Houve obstrução da válvula, que chegou a ser trocada por outras duas vezes, mas, por fim, restou removida. Teve alta do hospital para cuidados domiciliares. Procurou outro serviço vários meses depois, já com um perímetro cefálico de $80 \mathrm{~cm}$ (média de um adulto é de $60 \mathrm{~cm}$ ), muito desnutrido; possivelmente, o peso da cabeça era de $70 \%$ do peso corporal total. A médica rotinista do serviço pediátrico possuía um irmão com paralisia cerebral e decidiu por investir esforços nesse paciente, que, nos 3 meses que durou sua internação, foi submetido a derivação ventricular externa, derivação ventrículoperitonial, derivação ventrículo-atrial, dissecções venosas profundas em femoral, braquial e cervical e uso prolongado e progressivo de antibióticos para infecções hospitalares. Faleceu em decorrência de pneumonia aspirativa, após ter sido reanimado duas vezes. Durante a internação, a mãe, a avó materna e por vezes o pai do menino se revezavam para acompanhar a criança. Mas, principalmente, a mãe passou a maior parte do tempo ao lado, e o casal tinha outras duas crianças, que ficaram na outra cidade sob os cuidados do pai e da avó materna. Os outros irmãos eram pequenos; o de cinco anos apenas visitou a irmãzinha em duas ou três ocasiões; o de dois anos nem sequer chegou a vê-lo.

Caso $n^{\circ}$ 3. (Provável obstinação terapêutica). Lactente do sexo feminino, com diagnóstico antenatal de agenesia do corpo caloso. O primeiro mês de vida transcorreu relativamente 
sem intercorrências, mas a partir do segundo mês de vida, evoluiu com distúrbios de deglutição e engasgos frequentes, tendo sido internada para tratamento de pneumonia. Durante a internação, evoluiu para estado epiléptico praticamente contínuo, refratário até mesmo a benzodiazepínico em infusão contínua. Apresentava fechamento de glote decorrente das descargas epilépticas, até que uma traqueostomia foi realizada. A primeira internação durou cerca de 40 dias, tendo a criança ido para casa em uso de dieta por sonda nasogástrica e traqueostomia, através da qual respirava. Viveu por três anos, não teve desenvolvimento neuropsicomotor, tendo apresentado apenas crescimento somático. Nesses três anos, apresentou cerca de 10 internações hospitalares por pneumonias; 0 período máximo que permaneceu no domicílio foi de 20 dias. Nesses três anos, chegou a ser internada em UTI cerca de cinco vezes nesses três anos de vida. Nos últimos quinze dias de vida, apresentava instabilidade respiratória, com necessidade de alto fluxo de oxigênio. Estava intubada, em ventilação mecânica, aguardando novamente vaga em UTI, quando apresentou quatro paradas respiratórias no intervalo de dois dias, vindo a óbito em decorrência de insuficiência respiratória intratável. No contexto familiar, a mãe recebeu benefícios financeiros sociais e, nos três anos de vida da criança, dedicou-se totalmente a ela, tendo pedido demissão do emprego e também enfrentou um divórcio quando a menina tinha cerca de dois anos de vida; o pai da criança poucas vezes revezou com a mãe durante a internação e, segundo a mãe, ele reclamava que a mãe se esquecera de viver em função da filha, que nitidamente não sobreviveria muito tempo. Segundo o pai, o problema não era tanto a necessidade de cuidados da filha, mas a postura da mãe em terse anulado e vivido apenas para aquela criança. Com o óbito da criança, cessaram os benefícios financeiros e ela viu-se novamente tentando colocação no mercado de trabalho. Não há registro que o casal tenha se reconciliado.

\section{Análise dos casos}

Os casos relatados são reais e refletem como a pediatria brasileira aborda os cuidados de fim de vida de crianças com malformações cerebrais graves. Ao contrário, em todos os casos, foi notória a tendência de cuidados intensivos realizados de forma automática e obstinada. 
O primeiro caso revela o risco de extremismos éticos quando há protocolos aceitos de limitação terapêutica. De fato, o bebê anencéfalo, em termos gerais, apresenta curtíssima expectativa de vida e não se deve realizar maiores investimentos terapêuticos. Mas o caso relatado é uma nítida exceção à regra, na qual o bebê não só estava vivo como apresentava uma intercorrência infecciosa não-respiratória. A primeira questão é se o uso de antibióticos nesse caso é uma medida fútil ou é um cuidado essencial. Provavelmente, nem é fútil e nem é essencial: a posição de futilidade seria relativa à própria condição de morte iminente pela anencefalia. A posição de cuidado essencial seria relativa ao fato que antibiótico por alguns dias não é um tratamento penoso, ainda mais quando as veias estão íntegras e acessos vasculares são relativamente simples de obter.

No entanto, o caso em estudo se torna ainda mais interessante porque não bastou um bebê anencéfalo ter desenvolvido uma infecção urinária, mas ainda porque a referida infecção estava sendo causada por uma bactéria multirresistente para a qual não há antibióticos disponíveis. Ou seja, caso o bebê houvesse sobrevivido mais tempo, quando o resultado dos exames houvesse chegado, teria sido necessário trocar os antibióticos de forma quase que totalmente experimental, ou seja, investir no tratamento desse paciente iria dar experiência clínica à equipe para tratar eventuais futuras infecções por essa cepa bacteriana. Mas também teria exigido logística de isolamento de contato por parte do hospital.

Então, uma primeira pergunta: quais tratamentos instituir ou sonegar a um bebê anencéfalo que aos 40 dias de vida apresenta uma intercorrência clínica? Nesse ponto, a diretriz médica geral é a de não-reanimação (primeira etapa da limitação terapêutica), provavelmente seguida pela sonegação de intubação/ventilação mecânica e aminas vasoativas, tratamentos drásticos. Mas a postura do plantonista foi a de não instituir tratamento algum, e simplesmente mandar a criança para morrer em casa. Essa total falta de cuidado também não é o paradigma ético dos cuidados paliativos. Talvez esse bebê fosse mesmo morrer em casa, mas houve falta de um aspecto fundamental nos cuidados paliativos e limitação terapêutica: o diálogo.

Realmente, não houve tempo hábil para estabelecer algum tipo de diálogo entre os membros da equipe médica e os familiares. Mas se os familiares procuraram mais de um pronto-atendimento, nitidamente eles não desejavam ou não estavam prontos para assumir a morte domiciliar do paciente. Esse caso deixou isso bem claro: talvez os 
familiares não quisessem muita coisa, talvez apenas um 'sorinho na veia', mas eles queriam estar assistidos pelo Hospital.

A cultura médica do Hospital, ainda mais dos serviços de emergência, é a do Hospital como reparador da saúde. Quando o Hospital já não repara a saúde, mas apenas tem por função cuidados elementares, a equipe parece não ter mais bases de atuação e continuar seguindo o paradigma de atendimento curativo. Se não fosse assim, o segundo pronto-socorro, que já recebeu o paciente em estado terminal, não teria feito maiores investimentos, mas foi feita expansão volêmica e oxigênio nasal. Novamente, há que salientar que a limitação terapêutica é indicada frente à cronicidade de uma doença, cujo curso temporal começa a mostrar um declínio funcional cada vez maior. Nesse caso, apesar da extrema gravidade da doença de base, o paciente estava frente a até então sua primeira intercorrência clínica, uma infecção urinária, a qual inclusive escapa ao padrão mais usual desses pacientes, que seria uma afecção respiratória.

Ou seja, o desafio ético desse primeiro caso também expôs uma questão organizacional no atendimento: a de não ter havido um profissional coordenador que concatenasse as visões diametralmente opostas frente a esse paciente, quais sejam a de internar e tentar algum tratamento mais invasivo com antibiótico venoso versus mandar morrer no domicílio. A quem os familiares se reportariam para ter a posição de consenso da equipe e para expor suas necessidades? Foi nítida a total falta de diálogo com os familiares, e para tal, os desafios éticos dos cuidados paliativos/limitação terapêutica desafia a estrutura vigente: se o único paradigma do Hospital for o de investir maciçamente nos pacientes, basta haver plantonistas, ainda mais se a perspectiva em geral for de internações curtas. Mas quando o paradigma já exige um processo dialógico, é preciso que o sistema crie essa figura - a de um, ou alguns, coordenador(es) que terão a incumbência de representar a equipe.

A conclusão desse primeiro caso é a de evitar se falar em erro ou falha ética no atendimento - seja erro por obstinação terapêutica, seja erro por abandono de paciente. Jamais está sendo tratado em condenar esta ou aquela conduta, mas sim analisar, sistemicamente, como a estrutura de saúde foi frágil e incapaz de dar as respostas mais adequadas aos cuidados críticos de um paciente que já nasceu em contexto de terminalidade de vida - pela anencefalia. Não foram as condutas antagônicas o principal problema nesse caso, foi a ausência de uma postura ética e de uma conseqüente estrutura 
dialógica que pudesse expor aos familiares as limitações terapêuticas cabíveis e ouvir deles que tipo de suporte eles realmente buscavam no Hospital.

O segundo caso mostra, por sua vez, o lado oposto ao primeiro caso: parecia haver concordância dos familiares na postura de obstinação terapêutica, a qual prosseguiu pela total ausência de um protocolo a indicar limitações. Os Cuidados Paliativos têm por premissa o direito do paciente em ouvir segundas opiniões antes da decisão por limitação terapêutica. Assim, ao que parece, em a criança tendo um diagnóstico de terminalidade em um serviço, a família decidiu por procurar uma segunda opinião, e encontrou uma equipe coordenada por uma profissional que tinha seus próprios valores em decorrência de sua vivência pessoal com pacientes portadores de danos cerebrais, no caso, seu irmão mais jovem.

Esse item do segundo caso relatado traz à tona o aspecto, presente em toda literatura consultada: que também o profissional médico tem seus valores e suas vivências e isso não há como fugir no momento de tomada de decisões. Pode-se até contrastar o valor ético pessoal da equipe que optou por cuidados intensivos desse paciente com a decisão do plantonista do primeiro caso em ter dado simplesmente alta hospitalar: há uma nítida discrepância quanto aos valores pessoais de cada profissional, e isso influencia de forma diametralmente oposta sobre como conduzir os casos de final de vida.

Igualmente, foi nítido nesse segundo exemplo, que a expectativa de vida do paciente seria muito curta. Os pais buscaram tratamento, e nesse ponto a obstinação talvez nem tenha sido pela tentativa - ainda que remota - de aliviar a hipertensão intracraniana por meio da colocação de válvulas diversas. Seria, então, uma obrigação ética de se instituir esse tratamento? Ou nessas condições até mesmo a colocação de válvulas de derivação ventricular já seria um tratamento obstinado, e, portanto antiético?

No âmbito dos Cuidados Paliativos, ambas as respostas estão eticamente corretas, pois a questão não são protocolos de limitação tomados como referencial absoluto, mas sim, decorrentes de um processo dialógico, uma vez que os lados da questão apresentam suas razões e contrarrazões. Aliás, houve, novamente, falta de um espaço de diálogo, primeiro dentro da própria equipe médica, a qual poderia concordar com a tentativa de funcionamento de uma válvula de derivação de líquor e também com o suporte inicial às eventuais intercorrências - obstrução ou infecção.

Mesmo assim, no mínimo uma decisão de não-reanimação poderia ter sido expressamente realizada, dado o consenso da gravidade e irreversibilidade do quadro 
clínico. E, em seguida à ordem de não-reanimação, outras limitações bastante razoáveis e consensuais poderiam ter sido obtidas, como: não-indicação de leito em UTI, nãoindicação de intubação endotraqueal entre outras. A questão do uso de antibióticos também adquiriu contornos bastante peculiares nesse caso: não houve uma intercorrência infecciosa, mas várias, em um regime de internação hospitalar, portanto, por bactérias supostamente multirresistentes. O uso do antibiótico, por si, não necessariamente é obstinação terapêutica, dado que geralmente não é um tratamento penoso nem doloroso. Mas quando todas as veias da criança tiveram que ser cirurgicamente dissecadas para a administração de antibióticos em um contexto de terminalidade de vida, definitivamente viu-se uma prática obstinada a aumentar o sofrimento do pequeno paciente.

É pouco provável que venha haver uma diretriz específica para o caso do paciente: quais tratamentos são obstinados em caso de hidrocefalia grave. Certamente, é o tipo da situação para a qual não se espera um protocolo específico, mas diretrizes gerais de caracterização de terminalidade de vida e o subseqüente procedimento dialógico de decisão acerca dos limites éticos à intervenção médica.

O terceiro caso ilustra as questões levantadas na revisão de artigos, em particular o suporte respiratório por traqueostomia e dieta por sondagem. De fato, a despeito da condição grave da criança, o diagnóstico clínico antenatal - agenesia do corpo caloso indica que há possibilidade de sobrevida por prazo indefinido e até mesmo alguma independência social. Dessa forma, aos 40 dias de vida, não era possível predizer a expectativa acerca da criança, de modo que os suportes respiratório e nutricional se faziam necessários. Novamente, é um exemplo de como suporte nutricional para crianças com malformações cerebrais não é, por si, um tratamento obstinado: ao longo de toda a sua vida, a nutrição por sonda nasogástrica transcorreu sem maiores intercorrências, tendo permitido o crescimento somático. A curta expectativa de vida começou a ser traçada de forma lenta e insidiosa, quando não se observou nenhum tipo de desenvolvimento neuropsicomotor, ao mesmo tempo em que essa criança começou a apresentar repetidas intercorrências respiratórias. Após a primeira alta da UTI, a situação de obstinação terapêutica já começou a ficar evidente, pois pouco após a alta, uma nova intercorrência respiratória aconteceu. Ou seja, o terceiro caso é o típico exemplo que para as malformações cerebrais, a indicação ética de limitação terapêutica não necessita de um protocolo rigoroso e padronizado para cada uma das malformações existentes. Em conjunto, é possível notar indícios de clara obstinação terapêutica, como nesse caso: após 
a primeira alta da UTI, já seria o momento de no mínimo indicar uma ordem de nãoreanimação e uma eventual não-indicação futura de ida para UTI. Mas, ao invés, essa criança foi submetida a várias manobras de reanimação para o esperado desfecho letal.

\section{DISCUSSÃO GERAL E CONSIDERAÇÕES FINAIS}

Normalmente, quanto mais grave é uma doença, mais recursos biomédicos são empregados em seu combate. Ou seja, para quadros clínicos graves, é preciso tratamentos intensivos e drásticos. No entanto, desde o final da década de 1960, já houve a percepção ética que para quadros extremamente graves, um outro tipo de tratamento drástico era necessário: o de justamente limitar e não utilizar de toda a tecnologia disponível.

Os cuidados paliativos foram desenvolvidos, inicialmente, para cuidados de pacientes com câncer, que em sua fase terminal experimentavam um momento de dor total em decorrência dos tratamentos intensivos de suporte de vida. Ou seja, na fase terminal de câncer, já restou muito evidente que o tratamento médico deveria ser restrito aos cuidados paliativos, ou seja, cuidados de alívio dos sintomas desconfortáveis. Da experiência com esses pacientes, ficou evidente a postura ética que nem todo tratamento intensivo deve ser empregado a todos os pacientes, indistintamente. A noção de limitação terapêutica pelo bem do próprio paciente reside no fato que todo tratamento, mas principalmente os tratamentos intensivos, apresentam inúmeros efeitos colaterais e eles são, por si mesmos, causadores de desconforto.

Essa primeira conclusão ética funciona como um contrapeso o que foi a mola propulsora de todo o desenvolvimento tecnológico na área biomédica, ou seja, o de combate intensivo e exaustivo às diversas doenças, e com isso prolongar cada vez mais e mais a expectativa de vida de uma pessoa. Ou seja, a ética dos Cuidados Paliativos é, literalmente, subversiva, ao menos em parte, porque subverte esse paradigma na sua antítese, ou seja, passa-se de 'tratamentos intensivos' para 'não-tratamentos'. E isso, para fins práticos e concretos, mostra-se de uma complexidade ética, mas também técnica, muito grande. 
De uma noção ética genérica e abstrata que nem todo tratamento é para todo paciente, como, então, concretizar para cada caso concreto: quais tratamentos não servem para este dado paciente? E, mais ainda, para um dado paciente, quais tratamentos devem ser retirados, porque o tratamento está sendo pior do que a própria doença? A resposta já não é tão simples. Há respostas. Mas elas são complexas. Ou seja, a limitação terapêutica aos cuidados paliativos envolve duas decisões, uma subsequente à outra: 1) a qual paciente ser indicada a limitação terapêutica; 2) quais recursos terapêuticos serão restritos.

Assim, primeiramente à questão de 'a quem indicar limitação de tratamentos': no caso dos cânceres, para cada tipo de câncer, há sólida documentação na literatura acerca de estadiamento, prognóstico e história natural, com e sem tratamentos, que embasa, se não protocolos, ao menos diretrizes gerais que apontam a quais pacientes é indicada a limitação terapêutica aos cuidados paliativos. De forma similar, para outras doenças crônicas, como insuficiência cardíaca ou doença pulmonar obstrutiva crônica, tem havido a publicação de índices, que não são tomados de forma absoluta, mas que ao menos guiam a respeito de condições clínicas nas quais a limitação ética aos cuidados paliativos pode ser indicada ou discutida.

Mas, uma vez presente a idéia que existe um tratamento drástico - o nãotratamento - que é eticamente a melhor decisão para um grupo de pacientes, a prática clínica se defronta com situações as mais variadas possíveis e inimaginadas, por exemplo, no âmbito da geriatria, se o fato de um idoso previamente sadio que sofra um revés agudo e grave em sua saúde é, genericamente, um candidato à limitação terapêutica.

Outra situação bastante difícil é a indicação de limitação terapêutica para a faixa etária pediátrica. Por mais que seja doloroso admitir, muitas crianças vivem sua infância já em um contexto de terminalidade de vida, ou seja, em paralelo com algum desenvolvimento somático e neuropsicomotor, ocorrem agravos à saúde que levarão ao óbito. $E$ isso a medicina atual não pode impedir.

Dentre as causas de terminalidade de vida na faixa etária pediátrica - cânceres, erros inatos do metabolismo, prematuridade extrema, malformações de órgãos vitais estão as malformações cerebrais. As malformações cerebrais redundam em mecanismos de mortalidade mais complexos e distintos comparativamente ao câncer. Enquanto o câncer é uma doença progressiva e consumptiva, as lesões cerebrais cursam com incoordenação de sistemas, o que se expressa por períodos assintomáticos seguidos de 
intercorrências clínicas diversas - convulsões de difícil controle, pneumonias aspirativas, subnutrição por deficiência de deglutição, etc.

Ou seja, as crianças portadoras de malformações cerebrais não necessariamente são indicadas para a limitação terapêutica aos cuidados paliativos; primeiramente, é preciso delinear a gravidade e o impacto da malformação para a saúde. Não obstante, as malformações cerebrais comumente se associam a síndromes diversas, como cromossomopatias e outras malformações orgânicas, de modo que se avalia a condição clínica geral do paciente.

Se em tese uma criança portadora de malformação cerebral for elegível para cuidados paliativos exclusivos, a próxima questão que se insere é: quando? O simples fato de uma criança apresentar uma determinada malformação não é, no geral, suficiente para indicar a limitação terapêutica: é preciso, antes, verificar o curso clínico ao longo da infância para então diagnosticar a situação de terminalidade e a subsequente indicação de limitação terapêutica.

Dentre as malformações cerebrais, a anencefalia apresenta uma diretriz ética que reconhece a franca terminalidade e por conseguinte a desobrigação médica de utilizar-se de tratamentos intensivos de suporte vital. Essa condição clínica abre margem a duas situações: uma, mais rara, de crianças anencéfalas que por algum motivo sobrevivem ao período neonatal imediato. Para esses poucos pacientes, há uma dúvida ética de quais tratamentos tornam-se, então, minimamente obrigatórios. Outra discussão é que há outras malformações cerebrais - como esquizoencefalia, lisencefalia, etc - que apresentam gravidade similar: se não cursam com óbito neonatal imediato, cursam com degeneração clínica tamanha que o óbito advém ainda no primeiro ano de vida. Então, onde está a literatura, a estatística, o dado de história natural que sustenta a postura ética de limitação terapêutica para essas outras condições clínicas? Afinal, a limitação terapêutica frente à anencefalia está embasada em amplos dados estatísticos e de curso clínico natural dessa malformação. Ou seja, é um dos aspectos mais contundentes que a pesquisa em cuidados paliativos ainda tem muito por fazer.

Uma vez que o paciente tenha uma condição clínica para a qual se indique limitação terapêutica e uma vez que a situação clínica aponte que esse momento tenha chegado, parte-se, então, para a questão de quais recursos terapêuticos são restritos.

A primeira etapa da limitação terapêutica é a ordem de não reanimação cardiorrespiratória. A ordem de não-reanimação é mais um evento de valor simbólico do 
que propriamente uma limitação terapêutica. Afinal, as manobras de reanimação cardiorrespiratória - compressão torácica, ventilação com pressão positiva - por vezes associadas a outros insumos - apresentam uma taxa geral relativamente baixa de sucesso, da ordem de 30\%. Ou seja, é possível que mesmo o paciente terminal responda às manobras de reanimação, mas certamente não terá alta hospitalar.

A partir da ordem de não-reanimação, pode-se pensar em outros tratamentos a serem limitados. De uma forma bastante intuitiva, cirurgias de grande porte já são contraindicadas, mas há vários procedimentos cirúrgicos que podem aliviar sintomas desagradáveis e que são, portanto, indicados. Mas o suporte de maior conflito ético é justamente o suporte respiratório invasivo. Na ausência de suporte respiratório, o óbito é praticamente imediato. Essa situação abre discussão para um importante dilema ético na limitação terapêutica que é a comparação entre suspensão e sonegação de tratamento. Não intubar um paciente terminal é o mesmo que extubar um paciente terminal? Abstratamente, a corrente bioético-filosófica conclui, inclusive sob auspícios jurídicos, que trata-se do mesmo fato. No entanto, a percepção ética geral é que são claramente distintos, pois, quando não se intuba um paciente, apenas não se usa a probabilidade do risco versus benefício, ou seja, em nome da prudência, não há exposição ao risco de efeitos colaterais e sensações desagradáveis, enquanto frente ao paciente intubado já se conhece a resposta clínica à ventilação mecânica.

Nesse ponto, a pesquisa de Tan et al. (2006) esclarece que as duas vertentes bioéticas estão corretas: quando se verifica a curva de mortalidade entre os grupos 'sonegação' e 'suspensão', em uma fase inicial a mortalidade de ambos se equivale. Em um prazo médio, contudo, o grupo 'sonegação' apresentou maior sobrevida que o grupo 'suspensão'.

Ou seja, esse dado, conforme confirmado ou infirmado por outros trabalhos, indica que tanto ética como tecnicamente, a sonegação de ventilação mecânica é preferível à sua suspensão. Vários fatores podem explicar esse fato, tais como: quando se sonega, não se expõe o paciente aos efeitos deletérios do procedimento invasivo (irritação de mucosa, edema de glote, etc); a sonegação de ventilação invasiva é seguida de um cuidado maior em suporte não-invasivo, como oxigênio por cateter, limpeza nasal mais frequente, etc. Outra hipótese também é que o grupo a quem foi suspenso o tratamento, inicialmente não era elegível para cuidados paliativos, mas foi justamente a intercorrência aguda que, frente 
à situação crônica de base, mostrou-se mais grave e arrastada do que inicialmente esperado.

Aliás, a pesquisa continuada em cuidados paliativos fez retirar um debate recorrente até recentemente: o limite ético da sedação e analgesia terapêutica. Isso porque um dos pilares dos cuidados paliativos - justamente a sedação e a analgesia, quando feitas mediante o uso de fármacos potentes, apresentam como efeito colateral possível a depressão do sistema respiratório. No entanto, as revisões sistemáticas mostraram que há um protocolo de aumento progressivo nas doses desses fármacos e que, na verdade, os pacientes que recebiam doses mais elevadas tendiam a apresentar uma sobrevida maior. Ou seja, não se devem iniciar esses fármacos em doses altas, pelo risco de depressão do sistema respiratório. Mas conforme a deterioração clínica do paciente faça exigir doses maiores, elas podem e devem ser usadas.

Com relação à ventilação mecânica - e isso é importante ficar claro para o leigo há duas situações nas quais é eticamente indicada sua suspensão: uma, quando a despeito do suporte intensivo, ou seja, altos parâmetros ventilatórios (pressão, oxigênio, frequência respiratória), o paciente demonstra sinais prolongados (vários dias) de insuficiência respiratória (hipóxia ou hipercapnia). Outra, mais complexa, quando o suporte respiratório encontra-se em padrões habituais, mas há outras comorbidades graves. Devese salientar que não basta haver falência do suporte ventilatório para se indicar sua suspensão: é preciso que essa situação seja sobreposta a um histórico prévio de doenças, a uma condição crônica de base, onde é possível reconhecer a prática da obstinação terapêutica.

A problemática da criança com malformação cerebral, em termos mais concretos, se caracteriza pela possível indicação de sonegação ou suspensão de nutrição enteral por sonda. Não se trata, neste ponto, de discutir se é cabível ou não essa medida - a tendência mundial geral é de considerar isso uma forma antiética de eutanásia - mas de reconhecer que, em certos países do mundo, a ética médica considera válida a suspensão de nutrição por sonda em crianças em estado comatoso persistente mesmo que elas não estejam vivenciando uma intercorrência clínica, ou seja, na ausência de respostas cognitivas de sofrimento ou de autopercepção, há o viés neuroético de relativizar esse tipo de cuidado.

Independentemente da malformação cerebral, a limitação terapêutica na faixa etária pediátrica, portanto, não escapa a uma condição de heteronomia. Mas, mesmo em 
comparação ao adulto mentalmente capaz, a limitação terapêutica é decorrente de um processo dialógico entre a equipe médica e o paciente. A heteronomia da criança é tida, na verdade, como um caráter de tutela, como uma fase da vida humana a ser protegida. $A$ criança deve ser protegida tanto dos perigos externos quanto de sua própria imaturidade. No caso da criança, quem responde são os pais. Em algumas situações, o médico pode representar o poder estatal que, em seu papel de tutela e proteção à infância, indique limitação terapêutica, mas os pais nitidamente desejam uma prática de obstinação terapêutica.

A condição heterônoma da criança reforça inclusive, do ponto de vista ético, mesmo para o cuidado paliativo do adulto, o caráter dialógico da decisão de limitação de esforços terapêuticos. Ou seja, o médico, isoladamente, é incumbido do poder de indicar tratamentos em geral, sobretudo em situações de urgência e emergência. Mas, sozinho, o médico não tem o poder de indicar a limitação terapêutica. A indicação e prescrição de limitação terapêutica, como mostrado, é uma tarefa institucional. Não exatamente de comitês de ética, que devem ser acionados apenas em situações de conflito, mas sim da equipe médica de assistência direta. É possível que duas instituições de saúde geograficamente próximas cheguem a conclusões distintas quanto ao momento de indicação de limites de esforços e mesmo a quais tratamentos são minimamente obrigatórios.

De todo modo, para a implementação de práticas de limitação terapêutica, foi preciso que os serviços de saúde se organizassem nesse sentido e absorvessem essa como uma de suas funções. A morte continua sendo o evento inexorável contra o qual o ser humano se indigna; portanto, a morte é, essencialmente uma coisa ruim e indesejada. Assim, para o serviço de saúde, não se trata de prover uma boa morte, mas de, diante da tecnologia biomédica desenvolvida, de seus limites e de seus efeitos colaterais, prover uma boa gestão médica de cuidados de fim de vida.

Assim, em termos administrativos, uma primeira conclusão após a ordem de nãoreanimação é uma ordem de não-internação em unidade de terapia intensiva. Justamente o nome já diz - a unidade é de cuidados intensivos, e aquele determinado paciente é indicado para cuidados paliativos. No entanto, a experiência mundial relatada na literatura é que, embora haja serviços específicos de cuidados paliativos para adultos, as crianças gravemente enfermas são cuidadas em serviços gerais de pediatria, voltados, essencialmente, para cuidados intensivos, de modo que, no momento atual, na faixa etária 
pediátrica, a própria UTI tem se incumbido da tarefa de propor suspensão e sonegação de tratamentos. No ideal de Cecily Saunders, contudo, os serviços de cuidados paliativos deveriam ser realizados em alas distintas dos locais de cuidados intensivos.

Seja em que situação for, é preciso, que a limitação terapêutica seja um consenso de equipe e que essa equipe tenha um líder, coordenador ou chefe a quem o paciente se reporta. O coordenador, evidentemente, tem seus valores e sua postura ética pessoal, mas essas decisões não são pessoais nem infundadas, mas sim, dialogadas. Fica nítido, portanto, que a iniciativa pela proposta de limitação terapêutica é da equipe médica e que essa proposta deve ser dialogada com os pais ou responsáveis pela criança. Em ambientes de urgência e emergência, a equipe médica trabalha sempre com decisões muito rápidas, mas o diálogo pela limitação terapêutica é algo que surge aos poucos e é uma decisão a ser tomada após uma ou mais reuniões em ambiente apropriado.

Gracia (2010) cita que os problemas éticos devem ser situados em quatro eixos: as indicações médicas, as preferências dos pacientes, a qualidade de vida e os fatores socioeconômicos. Pois bem, com relação aos fatores socioeconômicos, no Brasil, as crianças portadoras de malformações cerebrais graves tendem a ser submetidas a condutas de obstinação terapêutica, e isso é um problema de saúde pública que precisa ser discutido e enfrentado. Murray \& Line (2015) mapearam a situação dos cuidados paliativos ao redor do mundo. Ao momento de 2015, o panorama mundial mostra dois grupos relativamente separados: os países de maior renda per capita possuem serviços de cuidados paliativos de abrangência muito maior que os países de renda mais baixa. Ou seja, tal como observado pelo grupo paquistanês de Hirani \& Rahman (2012), a desassistência dos serviços de saúde coexiste com a obstinação terapêutica. Limitação terapêutica não é abandonar o paciente à própria sorte, mas sim prover os cuidados paliativos adequados.

\section{REFERÊNCIAS BIBLIOGRÁFICAS}

Academia Nacional de Cuidados Paliativos. Critérios de Qualidade para os Cuidados Paliativos no Brasil. Rio de Janeiro: ANCP; 2006.

Academia Nacional de Cuidados Paliativos. Manual de Cuidados Paliativos. Rio de Janeiro: Diagraphic Editora; 2009. 
Agamben G. Homo sacer: o poder soberano e a vida nua. Belo Horizonte: Editora UFMG; 2007.

Almeida EHR. Dignidade, autonomia do paciente e doença mental. Revista Bioética 2010a; 18(2): 381-395.

Almeida JLT, Schramm FR. Paradigm shift, metamorphosis of medical ethics and the rise of bioethics. Cadernos de Saúde Pública 1999; 15(sup.1): 15-25.

Almeida LD. Suscetibilidade: novo sentido para a vulnerabilidade. Revista Bioética 2010b; 18(3): 537-548.

Almeida LD, Machado MC. Atitude médica e autonomia do doente vulnerável. Revista Bioética 2010; 18(1): 165-183.

Almeida MS. Os profissionais de saúde e a terminalidade da vida: um estudo sobre os desafios éticos. Brasília. Dissertação [Mestrado em Ciências da Saúde] - Universidade de Brasília; 2010c.

Amaral JG, Yanaga RH, Geissler HJ, Neto AC, Bruck I, Antoniuk S. Esquizencefalia relato de onze casos. Arquivos de Neuropsiquiatria 2001; 59(2-A): 244-249.

Ambler $\mathrm{J}$. When is the right time? Complex issues around withdrawing life-sustaining treatment in children. South African Medical Journal 2014; 104: 507-509.

Andorno R. A noção paradoxal de dignidade humana. Revista Bioética 2009; 17(3): 435449.

Alonso JP. Contornos negociados del buen morir: la toma de decisiones médicas en el final de la vida. Interface - Comunicação, Saúde, Educação 2012; 16(40): 191-203.

Araújo AA, Brito AM, Novaes M. Saúde e autonomia: novos conceitos são necessários?Revista Bioética 2008; 16 (1):117-124.

Barchifontaine CP, Zoboli ELCP. Bioética, Vulnerabilidade e Saúde. São Paulo: Centro Universitário São Camilo; 2007

Barroso LR, Martel LC. A morte como ela é: dignidade e autonomia individual no final da vida. In: Gozzo D, Ligiera WR. Bioética e direitos fundamentais.São Paulo: Saraiva; 2012. 
Basu R. End of life care in pediatrics. Pediatric Clinics of North America 2013; 60: 725-739.

Beauchamp TL, Childress JF. Princípios de Ética Biomédica. São Paulo: Edições Loyola; 2002.

Benarroz MO, Faillace GBD, Barbosa LA. Bioética e nutrição em cuidados paliativos oncológicos em adultos. Cadernos de Saúde Pública 2009; 25(9): 1875-1882.

Biondo CA, Silva MJP, Secco LM. Dysthanasia, euthanasia, orthotanasia: the perceptions of nurses working in intensive care units and care implications. Revista Latinoamericana de Enfermagem 2009; 17(5): 613-619.

Bovens L. Child euthanasia: should we just not talk about it? Journal of Medical Ethics 2015; 41: 630-634.

Brook L, Hain R. Predicting death in children. Archives of Diseases in Childhood 2008; 93: 1067-1070.

Burlà C, Py L. Peculiaridades da comunicação ao fim da vida de pacientes idosos. Revista Bioética 2005; 13(2): 97-106.

Cabrera J. Sentido da vida e valor crucial da vida: uma diferença crucial. Philosophos 2004; 9(1): 7-28.

Cabrera, J. Estruturação do discurso bioético Il: coerência, argumentação e tolerância. In: Garrafa V, Kottow M, Saada A. Bases conceituais da bioética: enfoque latino-americano. São Paulo: Gaia; 2006.

Cabrera J. Metacríticas da linguagem: críticas de filosofia e psicanálise. É a noção de "inconsciente" analiticamente incompreensível? À procura de uma noção minimal. In: Margens das filosofias de linguagem: conflitos, aproximações entre analíticas, hermenêuticas, fenomenologias e metacríticas da linguagem. Brasília: Editora Universidade de Brasília; 2009.

Cadell S, Ho G, Jacques L, Wilson K, Davies B, Steele R. Considerations for ethics in multisite research in pediatric palliative care. Palliative Medicine 2009; 23: 274-275.

Calderón MY, Patziková TV, Naranjo IC. Presencia de la bioética en los cuidados paliativos. Revista Cubana de Medicina General Integral 2010; 26(2): 330-337. 
Capelas ML. Cuidados paliativos para recém-nascidos, crianças e jovens. Roma: Fondazione Maruzza Lefebvre D’Ovidio Onlus; 2009.

Castro LR, Zúñiga OM. Principales dilemas bioéticos en las personas con discapacidad prolongada. Acta Bioethica 2002; 8(1): 127-135.

Cate K, Vathorst S, Onwuteaka-Phlipsen B, Heide A. End of life decisions for children under 1 year in the Netherlands: decreased frequency of administration of drugs to deliberately hasten death. Journal of Medical Ethics 2015; 41: 795-798.

Christakis NA, Lamont EB. Extent and determinants of error in doctors' prognoses in terminally ill patients: prospective cohort study. British Medical Journal 2000; 320: 469-72.

Clark J, Dudzinski D. The culture of dysthanasia: attempting cpr in terminally ill children. Pediatrics 2013; 131:572-580.

Colby WH, Dahlin C, Lantos J, Carney J, Christopher M. The national consensus project for quality palliative care clinical practice guidelines domain 8: ethical and legal aspects of care. HEC Forum 2010; 22: 117-131.

Conselho Regional de Medicina do Estado da Bahia. Anencefalia e Supremo Tribunal Federal. Brasília: Letras Livres, 2004.

Conselho Regional de Medicina do Estado de São Paulo. Cuidado Paliativo. São Paulo: Cremesp, 2008.

Constantino CF, Hirschheimer MR. Dilemas éticos no tratamento do paciente pediátrico terminal. Revista Bioética 2005; 13(2): 85-96.

Cook KA, Mott S, Lawrence P, Jablonski J, Grady MR, Norton D, Liner K, Cioffi J, Hickey P, Reidy S, Connor J. Coping while caring for the dying child: nurses'experiences in and acute care setting. Journal of Pediatric Nursing 2012; 27: e11-e21.

DeVictor D, Latour J. Forgoing life support: how the decision is made in European pediatric intensive care units. Intensive Care Medicine 2011; 37: 1881 - 1887.

Diekema D, Botkin J. Clinical report - forgoing medically provided nutrition and hydration in children. Pediatrics 2009; 124: 813-822. 
Diniz D. Obstinação terapêutica em crianças: quando a morte é um ato de cuidado. Cadernos de Saúde Pública 2006; 22(8):1741-1748.

Diniz D, Ribeiro DC. Aborto por anomalia fetal. Brasília: Letras Livres; 2000.

Downing J, Powell R, Marston J, Huwa C, Chandra L, Garchakova A, Harding R. Children's palliative care in low and middle-income countries. Archives of Diseases in Childhood 2016; 101: 85-90.

Durall A, Zurakowski D, Wolfe J. Barriers to conducting advanced care discussions for children with life-threatening conditions. Pediatrics 2012; 129: e975-e982.

Enoch S, Roshan A, Shah M. Atendimento de emergência e cuidados iniciais para queimaduras. BMJ Brasil 2009; 2(14): 292-304.

Erichsen E, Danielsson EH, Friedrichsen M. A phenomenological study of nurses' understanding of honesty in palliative care. Nursing Ethics 2010; 17: 39-50.

Evans P, Saunders C. The management of fatal illness in childhood. Proceedings of the Royal Society of Medicine 1969; 62: 15-17.

Fabbro L. Limitações jurídicas à autonomia do paciente. Revista Bioética 1999; 7(1): 7-12.

Feltman D, Stokes T, Kett J, Lantos J. Is treatment futile for an extremely premature infant with giant omphalocele? Pediatrics 2014; 133: 123-128.

Feudtner C. Collaborative communication in pediatric palliative care: a foundation for problem-solving decision-maker. Pediatric Clinics of North America 2007; 54: 583-607.

Feudtner C, Nathanson P. Pediatric palliative care and pediatric medical ethics: opportunities and challenges. Pediatrics 2014; 133: s1-s7.

Filho EMR, Junges JR. Morte encefálica: uma dicussão encerrada? Revista Bioética 2015; 23(3): 485-494.

Figueira ACS. Consentimento e proteção de adultos e crianças: dilemas comuns e peculiares em países em desenvolvimento. Revista Bioética 2010; 18(3): 691-703.

Floriani C. Cuidados paliativos no domicílio: desafios aos cuidados de crianças dependentes de tecnologia. Jornal de Pediatria (Rio de Janeiro) 2010; 86(1): 15-20.

Floriani CA, Schramm FR. Cuidados paliativos: interfaces, conflitos e necessidades. Ciência e Saúde Coletiva 2008; 13(Sup.2): 2123-2132. 
Fornells HA. Cuidados paliativos en el domicilio. Acta Bioethica 2000; 6(1): 65-75.

Foucault M. O Nascimento da Clínica. Rio de Janeiro: Editora Forense-Universitária; 1977. Trad. Francês: Naissance de la clinique. Paris: Presses Universitaires de France; 1963.

Frader J, Michelson K. Can policy spoil compassion? Pediatric Critical Care Medicine 2007; 8(3): 293-294.

França $D$, Rego G, Nunes R. Ordem de não reanimar o doente terminal: dilemas éticos dos enfermeiros. Revista Bioética 2010; 18(2): 469-481.

França DNO, Azevêdo ES. Métodos e enfoques na produção de conhecimentos em bioética, anos 2001-2008, Revista Bioética do Conselho Federal de Medicina, Brasil. Revista Bioética 2010; 18(1): 155-163.

Freitas AFF, Seidl EMF. Estudo sobre heteronomia na assistência em saúde a crianças e adolescentes com necessidades especiais. Revista Bioética 2011; 19(1): 119-140.

Gaiva MAM. Pesquisa envolvendo crianças: aspectos éticos. Revista Bioética 2009; 17 (1): 135-146.

García-Salido A, Paso-Mora MG, Monleón-Luque M, Martino-Alba R. Palliative care in children with spinal muscular atrophy type I: what do they need? Palliative and supportive care 2015; 13: 313-317.

Garrafa V, Albuquerque. Enfoque bioético de lacomunicación en la relación médico paciente en las unidades de terapia intensiva pediátricas. Acta Bioethica 2001; 7(2): 355367.

Garrafa V, Prado MM. Saúde Pública, Justiça e Mercado: um olhar bioético sobre interesses inconciliáveis. Perspectives in Health. Washington: OPS/OMS; 2002.

Garros D. Uma boa morte em UTI pediátrica: isso é possível? Jornal de Pediatria 2003; 79(supl. 2): S243-S254.

Garros D, Rosychuk H, Cox P. Circumstances surrounding end of life in a pediatric intensive care unit. Pediatrics 2003; 112: e371-e379.

Gazzola LP, Melo FHC. Anencefalia e anomalias congênitas: contribuição do patologista ao Poder Judiciário. Revista Bioética 2015; 23(3): 495-504. 
Geller G, Harrisson K, Rusthon C. Ethical challenges in the care of children and families affected by life-limiting neuromuscular diseases. Journal of Developmental and Behavioral Pediatrics 2012; 33: 548-561.

Gerhardt C, Grollman J, Baughcum A, Young-Saleme T, Stefanik R, Klopfenstein K. Longitudinal evaluation of a pediatric palliative care educational workshop for oncology fellows. Journal of Palliative Medicine 2009; 12: 323 - 328.

Glaser BG, Strauss AL. Awareness of dying. Chicago: Aldline Publishing Company; 1965.

Gomes JCM. 2003. Aspectos éticos do diagnóstico pré-natal. Revista Bioética 2003; 11(2): 117-128.

Gomes MMS. Cuidados paliativos pediátricos - o desmoronar de um absurdo. Monografia [Mestrado Integrado em Medicina] - Faculdade de Medicina da Universidade do Porto; 2010.

Gort NB, Argota JV, Peraza MC. Maltrato infanto juvenil en discapacitados cognitivos. Revista Cubana de Medicina General Integral 2010; 26(2): 338-349.

Gracia D. Pensar a bioética: metas e desafios. São Paulo: Centro Universitário São Camilo; 2010.

Guimarães MC, Novaes SC. Autonomia reduzida e vulnerabilidade: liberdade de decisão, diferença e desigualdade. Revista Bioética 2005; 7(1): 21-24.

Gunn S, Hashimoto S, Karakozov M, Marx T, Tan I, Thompson D, Vincent J. Ethics roundtable debate: child with severe brain damage and and underlying brain tumour. Critical Care 2004; 8: 213-218.

Habermas J. A ética da discussão e a questão da verdade. São Paulo: Martins Fontes; 2007.

Ham C. Tragic choices in health care: lessons from the Child B case. British Medical Journal 1999; 319: 1258-1261.

Hidayat T, Iqbal Z, Nasir A, Mohamad N, Taib F. Can I give food or drink to my terminally ill child? Education in Medicine Journal 2015; 7(3): e73 - e78. 
Himelstein B, Hilden J, Boldt AM, Weissman D. Pediatric Palliative Care. New England Journal of Medicine 2004; 350: 1752 - 1762.

Hirani SAA, Rahman A. Child with idiopatic pulmonay hemosiderosis: a case report from Pakistan with multiple ethical and moral issues. Journal of Pediatric Nursing 2012; 27: e22e28.

Horta MP. Eutanásia - problemas éticos da morte e do morrer. Revista Bioética 1999; 7(1): 27-33.

Hynson JL, Aroni R, Bauld C, Sawyer SM. Research with bereaved parents: a question of how not why. Palliative Medicine 2006; 20: 805-811.

Jones $\mathrm{B}$, Contro $\mathrm{N}$, Koch $\mathrm{K}$. The duty of the physician to care for the family in pediatric palliative care: context, communication and caring. Pediatrics 2014; 133: S8- S15.

Junges JR, Cremonese C, Oliveira EA, Souza LL, Backes V. Reflexões legais e éticas sobre o final da vida: uma discussão sobre a ortotanásia. Revista Bioética 2010; 18(2): 275-288.

Junges JR. Bioética hermenêutica e casuística . São Paulo: Loyola; 2006.

Júnior RM. Neuroética: o cérebro como órgão da ética e da moral. Revista Bioética 2010; 18(1): 109-120.

Kaczor C. Against euthanasia for children: a response to Bovens. Journal of Medical Ethics 2016; 42: 57-58.

Kipper DJ, Hosne WS. Caso clínico. Revista Bioética 1998; 6(2): 95-106.

Kipper D. O problema das decisões médicas envolvendo o fim da vida e propostas para nossa realidade. Revista Bioética 1999; 7(1): 59-70.

Kipper D. Neuroética: uma reflexão metodológica. Revista Bioética 2011; 19(1):29-43.

Klein S. Moral distress in pediatric palliative care: a case study. Journal of Pain and Symptom Management 2009; 38: 157 - 160.

Kottow M. Bioética del comienzo de la vida: cuántas veces comienza la vida humana? Revista Bioética 2001; 9(2): 25-42. 
Kovacs M.J. Comunicação nos programas de cuidados paliativos. In: Pessini L, Bertachini L. Humanização e cuidados paliativos. Sao Paulo: Loyola; 2004.

Lacerda AF. A importância de cuidados paliativos em pediatria. Acta Pediatrica Portuguesa 2012; 43(5): 90-91.

Lago P, Devictor D, Piva J, Bergounioux J. Cuidados de final de vida em crianças: perspectivas no Brasil e no mundo. Jornal de Pediatria 2007; 83 (supl. 2): S109- S115.

Leewenburgh-Pronk W, Miller-Smith L, Forman V, Lantos J, Tibboel D, Buysse C. Are we allowed to discontinue medical treatment in this child? Pediatrics 2015; 135: 545-549.

Leone C. A criança, o adolescente e a autonomia. Revista Bioética 1998; 6(1): 51-54.

Lepargneur H. Dignidade da pessoa no desenrolar cultural. Revista Bioética 2004; 12(1): 33-38.

Levetown M. Communicating with children and families: from everyday interactions to skill in conveying distressing information. Pediatrics 2008; 121: e1441-e1460.

Lauterslager PFH. Anencefalia: consideraciones bioéticas y jurídicas. Acta Bioethica 2000; 6(2): 265-282.

Levine D. Discontinuing immunosupression in a child with a renal transplant: are there limits to withdrawing life support? American Journal of Kidney Diseases 2001; 38: 901- 915.

Liben S, Papadatou D, Wolfe J. Pediatric palliative care: challenges and emerging ideas. Lancet 2008; 371: 852-864.

Lucena GAB, Gomes MCLU, Vital R, Rêgo DM. Considerações éticas sobre o aborto e a doação de órgãos de fetos anencéfalos. Revista Bioética 2009; 17(3): 391-405.

Marconi MA, Lakatos EM. Técnicas de Pesquisa. 7ª . ed. São Paulo: Atlas; 2012.

Marreiro CL. Responsabilidade civil do médico na prática da distanásia. Revista Bioética 2013; 21(02): 308-317

Márquez $\mathrm{OCH}$. Objeción de conciencia, la muerte y el morir en enfermedades en etapa terminal. Acta Bioethica 2009; 15(1): 94-99.

Marta GN, Hanna SA, Silva JLF. Cuidados paliativos e ortotanásia. Diagnóstico e Tratamento 2010; 15(2): 58-60. 
Martin C. Deception and the death of llyusha: truth and the best interest of a dying child in The Brothers Karamazov. Pediatrics 2014; 134: s87-s96.

McQuold-Mason D. Can children aged 12 years or more refuse life-saving treatment without consent or assistance from anyone else? South African Medical Journal 2014; 104: 466-467.

Meneses EA, Souza MFB, Baruzzi RM, Prado MM, Garrafa, V. Análise bioética do diagnóstico de morte encefálica e da doação de órgãos em hospital público de referência no Distrito Federal. Revista Bioética 2010; 18(2): 397-412.

Menezes RA. Em Busca da Boa Morte. Rio de Janeiro: Editora Fiocruz; 2004.

Menin GE, Pettenon MK. Terminalidade de vida infantil: percepções e sentimentos de enfermeiros. Revista Bioética 2015; 23(3): 608-614.

Mercurio M, Murray P, Gross I. Unilateral pediatric 'do not attempt ressuscitation' orders: the pros, the cons and a proposed approach. Pediatrics 2014; 133: S37-S43.

Monte FQ. Ética médica: evolução histórica e conceitos. Revista Bioética 2009; 17(3): 407428.

Morais IM. Autonomia pessoal e morte. Revista Bioética 2010; 18(2): 289-309.

Morgan D. Caring for dying children: assessing the needs of the pediatric palliative care nurse. Pediatric Nursing 2009; 35: 86-90.

Morrisson W, Berkowitz I. Do not attempt ressuscitation orders in pediatrics. Pediatric Clinics of North America 2007; 54: 757-771.

Morrison W, Kang T. Judging the quality of mercy: drawing a line between palliation and euthanasia. Pediatrics 2014; 133: s31-s36.

Moritz RD. Os profissionais de saúde diante da morte e do morrer. Revista Bioética 2005; 13(2): 51-63.

Moritz RD, Deicas A, Capalbo M, Forte DN, Kretzer LP, Lago P, Pusch R, Othero J, Piva J, Silva NB, Azeredo N, Ropelato R. II Fórum do Grupo de Estudos do Fim da Vida do Cone Sul: definições, recomendações e ações integradas para cuidados paliativos na unidade de terapia intensiva de adultos e pediátrica. Revista Brasileira de Terapia Intensiva 2011; 23(1): 24-29.

Mota JAC. Quanto um tratamento torna-se fútil? Revista Bioética 1999; 7(1): 35-39. 
Munson D. Withdrawal of mechanical ventilation in pediatric and neonatal intensive care units. Pediatric Clinics of North America 2007; 54: 773-785.

Murray S, Line D. The 2015 quality of death index. Ranking palliative care across the world. Londres: The Economist Intelligence Unity; 2015.

Oliveira AAS, Montenegro S, Garrafa V. Supremo Tribunal Federal do Brasil e o aborto do anencéfalo. Revista Bioética 2005; 13(1): 79-92.

Nunes L. Ética em cuidados paliativos: limites ao investimento curativo. Revista Bioética 2008; 16(1): 41-50.

Nunes R. Proposta sobre suspensão e abstenção de tratamento em doenças terminais. Revista Bioética 2009; 17(1): 29-39.

Okhuysen-Cawley R, McPherson M, Jefferson L. Institutional policies on determination of medically inappropriate interventions: use in five pediatric patients. Pediatric Critical Care Medicine 2007; 8: 225-230.

Oliveira AC, Silva MJP. Autonomia em cuidados paliativos: conceitos e percepções de uma equipe de saúde. Acta Paulista de Enfermagem 2010; 23(2): 212-217.

Oliveira FT, Flávio DA, Marengo MO, Silva RHA. Bioética e humanização na final da vida: visão de médicos. Revista Bioética 2011; 19(1): 247-258.

Oliveira JR, Amaral CFS, Ferreira AC, Grossi YS, Rezende NA. Percepção bioética sobre a dignidade no processo de morrer. Revista Bioética 2009; 17(1): 77-94.

Oliveira RA. 2005. Terminalidade da vida em situação de morte encefálica e de doença incurável em fase terminal. Bioética 13(2): 77-83.

Palhares D, Cunha ACR. Ethical approach to aggressive situations involving dependent patients and doctors. Revista Latinoamericana de Bioética 2013; 13(1): 74-79.

Pelant D, McCaffrey T, Beckel J. Development and implantation of a pediatric palliative care program. Journal of Pediatric Nursing 2012; 27: 394-401.

Patias ND, Gabriel MR, Dias ACG. A família como um dos fatores de risco e proteção nas situações de gestação e maternidade na adolescência. Estudos e Pesquisas em Psicologia 2013; 13(2): 586-610. 
Penner L, Cantor RM, Siegel L. Joseph's Wishes: ethical decision-making in Duchenne muscular dystrophy. Mount Sinai Journal of Medicine 2010; 77: 394-397

Pessini L. Distanásia: até quando investir sem agredir? Revista Bioética 1996; 4(1): 31-43.

Pessini L. Distanásia: até quando prolongar a vida? São Paulo: Edições Loyola; 2001.

Pessini L. Distanásia: algumas reflexões bioéticas a partir da realidade brasileira. Revista Bioética 2004; 12(1): 39-60.

Pessini L. Dignidade humana nos limites da vida: reflexões éticas a partir do caso Terri Schiavo. Revista Bioética 2005; 13(2): 65-76.

Pessini, L. Ética do cuidado e humanização no mundo da saúde: questões de fim de vida. In:Bioética,poderes e injustiças: 10 anos depois. Porto D, Garrafa V, Martins GZ, Barbosa SN ( Coords.). Brasília: Sociedade Brasileira de Bioética; 2011.

Pessini L, Bertachini L. Nuevas perspectivas en cuidados paliativos. Acta Bioethica 2006; 12(2): 231-242.

Pinheiro J. Autonomia e aderência na pessoa com doença renal crônica. Revista Bioética 2011; 19(1): 219-229.

Piva JP, Garcia PCR, Lago PM. Dilemas e dificuldades envolvendo decisões de final de vida e oferta de cuidados paliativos em pediatria. Revista Brasileira de Terapia Intensiva 2011; 23: 78-86.

Phyrro M, Cornelli G, Garrafa V. Dignidad humana. Reconocimiento y operacionalización del concepto. Acta Bioethica 2009; 15: 24-33.

Porta I Sales J. Sedación en cuidados paliativos: reflexiones éticas. Acta Bioethica 2000; 6(1): 78-87.

Powell R. Dilemmas in the medical treatment of patients facing inevitable death. Archives of Diseases in Childhood 2007; 92: 746-749.

Priore M. História das crianças no Brasil. São Paulo: Editora Contexto; 2004. 
Puckey M, Bush A. Passage to paradise ethics and end-of-life decisions in children. Paediatric Respiratory Reviews 2011; 12: 139-143.

Rahimzadeh V, Bartlett G, Longo C, Crimi L, Macdonald ME, Jabado N, Ells C. Promoting an ethic of engagement in pediatric palliative care research. BMC Palliative Care 2015; 14: 50-57.

Ramnarayan P, Craig F, Petros A, Pierce C. Characteristics of deaths occurring in hospitalised children: changing trends. Journal of Medical Ethics 2007; 33: 255-260.

Rapoport A, Shaheed J, Newman C, Rugg M, Steele R. Parental perceptions of forgoing artificial nutrition and hydration during end-of-life care. Pediatrics 2013; 131: 861-869.

Rego S, Palácios M. A finitude humana e a saúde pública. Cadernos de Saúde Pública 2006; 22(8): 1755-1760.

Rego S, Palácios M, Siqueira-Batista R. Bioética para profissionais da saúde. Rio de Janeiro: Editora Fiocruz; 2009.

Renjilian C, Womer J, Carroll K, Kang T, Feudtner C. Parental heuristics in decision-making for children with life-threatening illnesses. Pediatrics 2013; 131: e566- e572.

Rezzónico CA. Bioética y derechos de los niños. Archivos Argentinos de Pediatría 2004; 102: 214-219.

Ribeiro C R. Proposta psicossocial para pacientes com enfermidades graves ou terminais. Revista Bioética 2011; 19(03):819-831

Rodrigues CFA. Alteridade da morte de Emmanuel Levinas. Revista Bioética 2012; 20(3): $442-450$.

Rodrigues JG. Como referenciar e citar segundo o Estilo Vancouver. Rio de Janeiro: Instituto de Comunicação e Informação Científica e Tecnológica em Saúde, 2008.

Ruppe MD, Feudtner C, Hexem K, Morrisson W. Family factors affect clinician attitudes in pediatric end-of-life decision making: a randomized vignette study. Journal of Pain and Symptom Management 2013; 45: 832 - 840. 
Sá, AR. O desvelar bioético entre gestação de anencéfalo e capacidade feminina de autonomia. Dissertação [Mestrado em Bioética] - Universidade de Brasília; 2014.

Salas R, Jodorkovsky M, Martínez JL. Límite de viabilidade en prematuros extremos: aspectos éticos. Revista Médica Clínica de las Condes 2008; 19(3): 278-283.

Sales JP. Sedación en cuidados paliativos: reflexiones éticas. Acta Bioethica 2000; 6(1): 79-87.

Sayeed S. Baby doe redux? The Department of Health and Human Services and the bornalive infants protection act of 2002: a cautionary note on normative neonatal practice. Pediatrics 2005; 116: e576- e585.

Salinas MM. La relación entre el equipo de salud y la família del niño muriente. Acta Bioethica 2011; 17(2): 247-256.

Schildmann J, Hoetzel J, Baumann A, Mueller-Busch C, Vollmann J. Journal of Medical Ethics 2011; 37: 327-332.

Schramm FR. O uso problemático do conceito vida em bioética e suas interfaces com a práxis biopolítica e os dispositivos de biopoder. Revista Bioética 2009; 17(3): 377-389.

Segre M, Silva FL, Schramm FR. O contexto histórico, semântico filosófico do princípio de autonomia. Bioética 1988; 6(1):15-23.

Shelton J, Jackson G. Palliative care and pediatric surgery. Surgical Clinics of North America 2011; 91: 419-428.

Siegel A, Sisti D, Caplan A. Pediatric euthanasia in Belgium. Disturbing developments. JAMA 2014; 311(19): 1963-1964.

Silva HB. O princípio da dignidade humana na Constituição brasileira. Revista Bioética 2010; 18(3): 573-587.

Silva LC, Mendonça ARA. Neonatologia e terminalidade da vida. Revista Bioética 2010; 18(3): 677-690.

Silva FM, Nunes R. Caso belga de eutanásia em crianças: solução ou problema? Revista Bioética 2015; 23(3): 475-484. 
Simone GG. El final de la vida: situaciones clínicas y cuestionamentos éticos. Acta Bioethica 2000; 6(1): 49-62.

Siqueira JE. Reflexões éticas sobre o cuidar na terminalidade da vida. Revista Bioética 2005; 13(2): 37-50.

Siqueira-Batista R, Schramm FR. Conversações sobre a boa morte: o debate ético da eutanásia. Cadernos de Saúde Pública 2005; 21(1): 111-119.

Siqueira-Bastista R, Schramm FR. A bioética da proteção e a compaixão laica. Ciência e Saúde Coletiva 2009; 14(4): 1241-1250.

Souza PVS. O médico e o dever legal de cuidar. Revista Bioética 2006; 14(2): 229-238.

Stayer D. Pediatric palliative care: a conceptual analysis for pediatric nursing practice. Journal of Pediatric Nursing 2012; 27: 350-356.

Stevens T, Wilde D, Paz S, Ahmedzai S, Rawson A, Wragg D. Palliative care research protocols: a special case for ethical review? Palliative Medicine 2003; 17: 482-490.

Swaiman K, Ashwal S, Ferriero D, Schor F. Swaiman's Pediatric Neurology - Principles

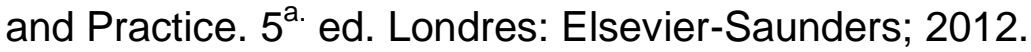

Taboada P. El derecho a morir con dignidad. Acta Bioethica 2000; 6(1): 91-101.

Tan G, Totapally B, Torbati D, Wolfsdorf J. Journal of Palliative Medicine 2006; 9: 332- 342.

Tavares MS. Aspectos éticos da quebra da relação médico-paciente. Revista Bioética 2008; 16(1): 125-131.

Tomlinson D, Bartels U, Hendershot E, Constantin J, Wrathall G, Sung L. Challenges to participation in pediatric palliative care research: a review of the literature. Palliative Medicine 2007; 21: 435-440.

Torres JCT, Goya LH, Rubia NH, Jimenez PN, Munóz FG, Rodríguez JP. Recomendaciones sobre toma de decisiones y cuidados al final de vida en neonatología. Anales de Pediatría 2013; 78(1): 190.e1-190.e14. 
Truog RD, Meyer EC, Burns JP. Toward interventions to improve end-of-life care in the pediatric intensive care unit. Critical Care Medicine 2006; 34 (suppl 11): S373- S379.

Tsai E. Withholding and withdrawing artificial nutrition and hydration. Paediatrics and Child Health 2011; 16: 241-242.

Turner H. Parental preference or child well-being: an ethical dilemma. Journal of Pediatric Nursing 2010; 25: 58-63.

Twycross R. Medicina paliativa: filosofía y consideraciones éticas. Acta Bioethica 2000; 6(1): 29-46.

Viallard ML. Some general considerations on a human-based medicine's palliative approach to the vulnerability of the multiple disabled child before the end of life. Culture, Medicine and Psychiatry 2014; 38: 28-34.

Villas-Bôas ME. Da Eutanásia ao Prolongamento Artificial. Rio de Janeiro: Editora Forense; 2005.

Villares JM,Eltzaga IV. Aspectos éticos en nutrición e hidratación en el niño. Comentarios al documento de la Academia Americana de Pediatría. Acta Pediatrica Española 2012; 70:15-19.

Vilela LP, Caramelli P. Knowledge of the definition of euthanasia: study with doctors and caregivers of Alzheimer's disease patients. Revista da Associação Médica Brasileira 2009; 55(3): 263-267.

Volpe J. Neurology of the newborn. $5^{\text {a. }}$ ed. Boston: Elsevier-Saunders; 2008.

Vose L. Ethical issues surrounding limitation and withdrawal of support in the pediatric intensive care unit. Journal of Intensive Care Medicine 1999; 14: 220-230.

Wanssa MCD. Autonomia versus beneficência. Revista Bioética 2011; 19(1): 105-117.

Wilfond B. Tracheostomies and assisted ventilation in children with profound disabilities: navigating family and professional values. Pediatrics 2014; 133: S44 - S49.

Wellesley $\mathrm{H}$, Jenkins I. Withholding and withdrawing life-sustaining treatment in children. Pediatric Anesthesia 2009; 19: 972-978.

Zinner S. The use of pediatric advanced directives: a tool for palliative care physicians. American Journal of Hospice and Palliative Medicine 2009; 25: 427-430. 